\title{
DEMONSTRATION OF THE GLYCOLIC- FORMIC FLOWSHEET IN THE SRNL SHIELDED CELLS USING ACTUAL WASTE
}

\author{
D. P. Lambert \\ J. M. Pareizs \\ D. R. Click
}

November 2011

Savannah River National Laboratory Savannah River Nuclear Solutions, LLC Aiken, SC 29808

Prepared for the U.S. Department of Energy under

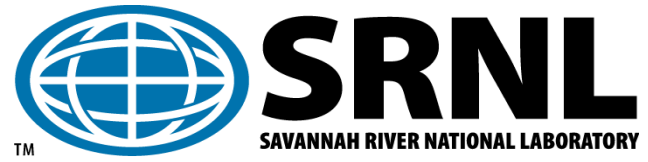
contract number DE-AC09-08SR22470. 


\section{DISCLAIMER}

This work was prepared under an agreement with and funded by the U.S. Government. Neither the U.S. Government or its employees, nor any of its contractors, subcontractors or their employees, makes any express or implied:

1. warranty or assumes any legal liability for the accuracy, completeness, or for the use or results of such use of any information, product, or process disclosed; or

2. representation that such use or results of such use would not infringe privately owned rights; or

3. endorsement or recommendation of any specifically identified commercial product, process, or service.

Any views and opinions of authors expressed in this work do not necessarily state or reflect those of the United States Government, or its contractors, or subcontractors.

\section{Printed in the United States of America \\ Prepared For \\ U.S. Department of Energy}


Key Words: DWPF, Sludge, Glycolic Acid, Formic Acid, Flowsheet

Retention: Permanent

\section{DEMONSTRATION OF THE GLYCOLIC- FORMIC FLOWSHEET IN THE SRNL SHIELDED CELLS USING ACTUAL WASTE}

D. P. Lambert

J. M. Pareizs

D. R. Click

November 2011

Savannah River National Laboratory Savannah River Nuclear Solutions, LLC Aiken, SC 29808 


\section{REVIEWS AND APPROVALS}

\section{AUTHORS:}

D. P. Lambert, Process Technology Programs

Date

J. M. Pareizs, Process Technology Programs

Date

D. R. Click, Analytical Development

Date

\section{TECHNICAL REVIEWER:}

M. E. Stone, Process Technology Programs

Date

J. D. Newell, Process Technology Programs

Date

\section{APPROVERS:}

C. C. Herman, Manager, Process Technology Programs

Date

S. L. Marra, Manager, Environmental \& Chemical Process Technology Research Programs Date

J. E. Occhipinti, Manager,

Date

Waste Solidification Engineering 


\section{EXECUTIVE SUMMARY}

The first run utilizing the Glycolic-Formic-Nitric Acid Flowsheet (referred to as the GlycolicFormic Flowsheet throughout this report) with actual waste was demonstrated in Shielded Cells Run 13 (SC-13). The Glycolic-Formic Flowsheet utilizes 4 moles of glycolic acid per mole of formic acid mixture (the reducing acid) to replace the formic acid used in the DWPF Sludge Receipt \& Adjustment Tank (SRAT) processing. Nitric acid, an oxidizing acid, is still also used. Other than the change in acids, there are no differences in the flowsheets. The testing was completed with a Tank 51 Sludge Batch 5 (SB5) slurry sample that was available. Some conclusions include:

- No significant issues with processing were noted. SC-13 SRAT cycle processing of Tank 51 -SB5 sludge met DWPF qualification criteria (nitrite was destroyed, mercury was removed, and hydrogen generation was below DWPF limits) with 12 hours of reflux.

- SSC-13 processing was comparable to the respective simulant work. The comparable simulant run (GF6 - 100\% Koopman acid stoichiometry and $1.45 \mathrm{~mol} / \mathrm{L}$ of acid added to a SB6 simulant) produced a peak hydrogen of $0.013 \mathrm{lb} / \mathrm{hr}$ DWPF-Scale, higher than observed in the SC-13 SRAT cycle.

The Glycolic-Formic Flowsheet has the following advantages over the current DWPF flowsheet:

- The hydrogen generation is greatly reduced as free formic acid concentration is much lower in the Glycolic-Formic Flowsheet. No catalytic hydrogen was detected throughout processing. The hydrogen detection limit of the gas chromatograph (GC) is 0.001 volume \%.

- The generation volume of carbon dioxide and nitrous oxide was approximately one-third what is typical in a baseline flowsheet run. This will reduce emissions and has the potential to lower foaming in the SRAT.

- Each mole of glycolic acid has two moles of carbon. To produce a melter feed with a balanced REDOX (as measured by $\mathrm{Fe}^{2+} / \Sigma \mathrm{Fe}$ ), this allows the use of more nitric acid and less reducing acid.

- Since little formic acid is used, there is little acid consumed during processing. This keeps the slurry at approximately the same $\mathrm{pH}$ throughout processing and avoids the high $\mathrm{pH}$ melter feeds that can be very thick and tacky.

- The Glycolic-Formic Flowsheet is able to dissolve a large fraction of the insoluble metals in the sludge. This is a combination of the chelating ability of glycolic acid and the use of more nitric acid. This makes the resulting slurry more fluid and allows more concentration (i.e., higher total solids) of the SRAT product without exceeding DWPF rheological limits.

- With lower hydrogen generation levels, the flowsheet offers a much larger acid window for processing than the current flowsheet.

- The glassware, $\mathrm{pH}$ probe, agitator and thermocouple post-testing were very clean compared to baseline flowsheet runs. The Glycolic-Formic Flowsheet's ability to dissolve metals is likely leading to fewer deposits and less scale build-up during processing.

In addition to being the first demonstration of the Glycolic-Formic Flowsheet with radioactive sludge, a prime focus was the determination of solubility of iron and fissile isotopes during processing. The use of iron as a neutron poison relies on its insolubility to prevent a criticality if mixing is lost. No Slurry Mix Evaporator (SME) cycle was performed because the preparation of the $\mathrm{pH} 3, \mathrm{pH} 2$, and $\mathrm{pH} 1$ SRAT products consumed virtually the entire SRAT product. During 
SRAT processing, the iron was very insoluble, with a peak solubility of $2.2 \%$ at a $\mathrm{pH}$ of 1 . It should be noted that a $\mathrm{pH}$ of less than 4 is not expected during normal processing. The data also indicated that a fraction of the fissile components in the sludge slurry became soluble.

- The soluble Pu-239 in solution had a concentration of $18.5 \mathrm{mg} / \mathrm{kg}\left(0.0427 \mathrm{~g}{ }^{239} \mathrm{Pu}\left(\mathrm{NO}_{3}\right)_{4} / \mathrm{L}\right.$, $0.58 \%$ of the $7.3 \mathrm{~g} / \mathrm{L}$ limit (ANS Standard for nuclear criticality safety).

- The Fe/Pu-239 ratio in the slurry was 383:1 at $\mathrm{pH} 1$, greater than the 160:1 Fe:Pu-239 safe weight ratio. The $\mathrm{Mn} / \mathrm{Pu}-239$ ratio in the slurry was $90.3: 1$ at $\mathrm{pH} 1$, greater than the 29:1 $\mathrm{Mn}: \mathrm{Pu}-239$ safe weight ratio.

Although the run was a successful demonstration utilizing the Glycolic-Formic Acid Flowsheet for DWPF SRAT processing of actual waste, no SME cycle was completed. As a result, it is recommended that:

- SRNL complete a SRAT/SME cycle using actual waste to demonstrate the entire flowsheet. Utilize the SME product to produce glass and measure resulting glass Reduction/Oxidation Potential (REDOX) potential.

- Continue developing and testing of the Glycolic-Formic Flowsheet to eliminate formic acid. This testing should be completed before the testing of the full Chemical Process Cycle (CPC) with radioactive slurry so the flowsheet to be used is demonstrated, which would reduce the number of radioactive demonstrations required. The use of a single acid would simplify acid procurement and processing in DWPF by reducing the hazards associated with formic acid. 


\section{TABLE OF CONTENTS}

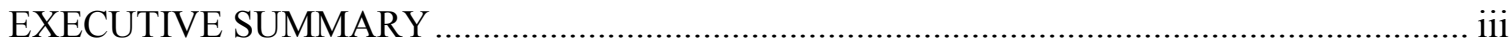

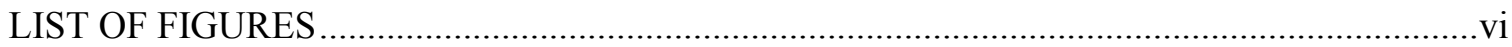

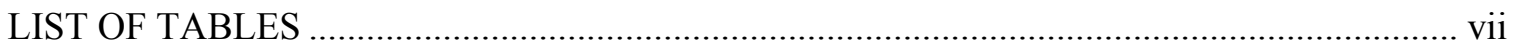

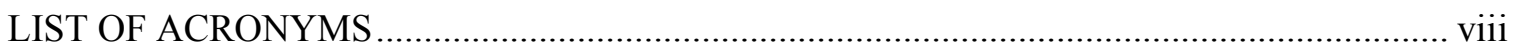

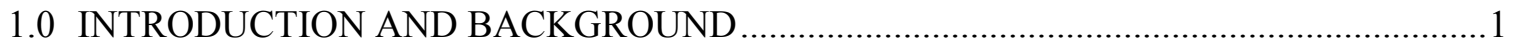

1.1 Development of the Glycolic-Formic Flowsheet ........................................................ 2

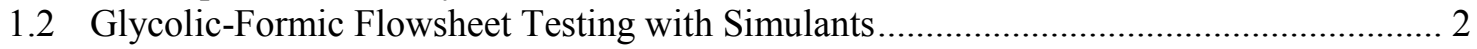

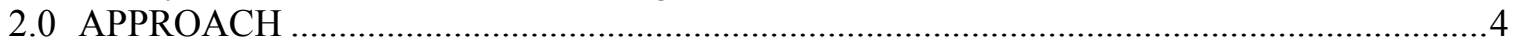

2.1 General Description of Analytical Methods................................................................. 4

2.2 Chemical Process Cell (CPC) Processing (SRAT Cycle, SME Cycle) …............................ 4

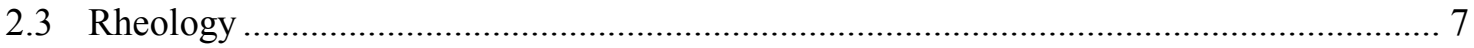

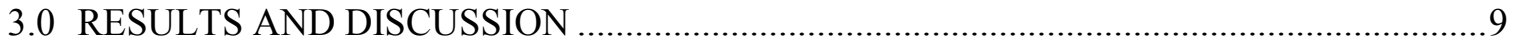

3.1 SRAT Receipt Characterization and Acid Addition Calculations .................................... 9

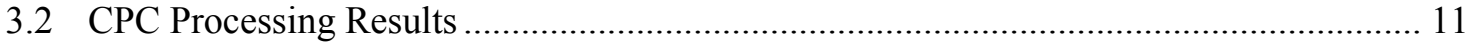

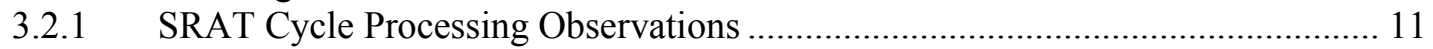

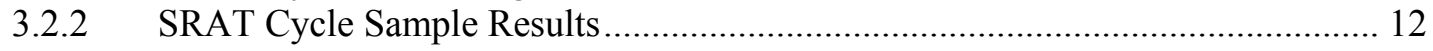

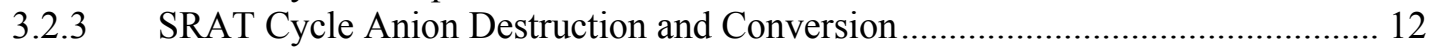

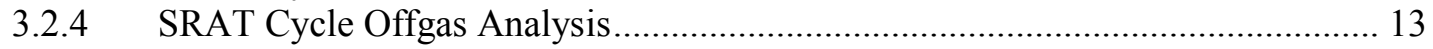

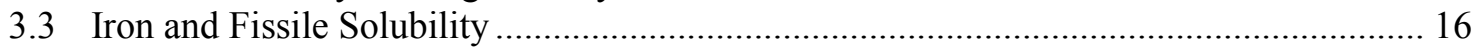

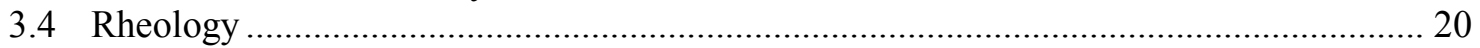

3.5 REDOX 20

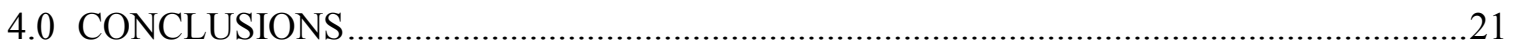

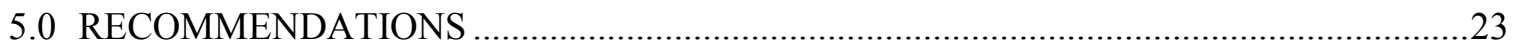

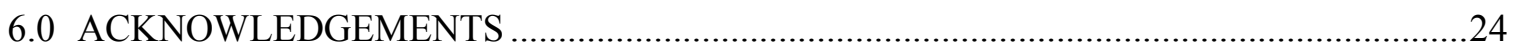

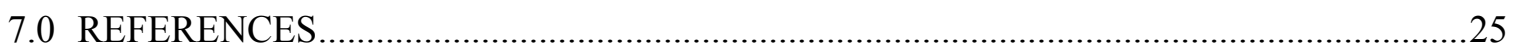

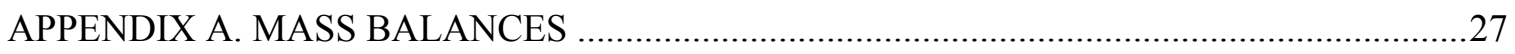

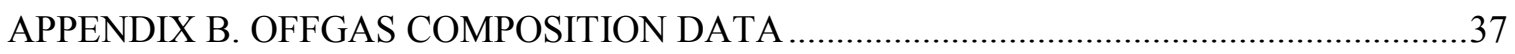

APPENDIX C. RHEOLOGICAL RESULTS CHARTS AND FLOW CURVES .......................41

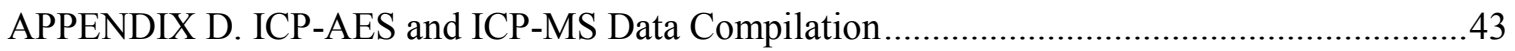




\section{LIST OF FIGURES}

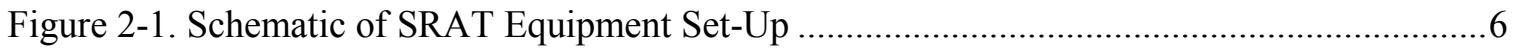

Figure 3-1. Hydrogen Generation during SC-13 SRAT Cycle ….................................................

Figure 3-2. Carbon Dioxide Generation during SC-13 SRAT Cycle ..........................................15

Figure 3-3. Nitrous Oxide Generation during SC-13 SRAT Cycle ............................................... 16

Figure 3-4. Iron Solubility as a Function of Acid Stoichiometry in Simulant Runs ......................17

Figure 3-5. Element Solubility from ICP-MS as a Function of Acid Stoichiometry ....................19

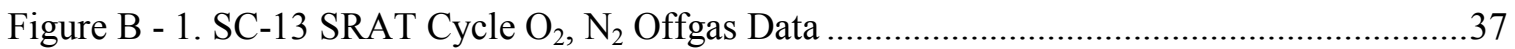

Figure B - 2. SC-13 SRAT Cycle $\mathrm{N}_{2} \mathrm{O}, \mathrm{CO}_{2}, \mathrm{H}_{2}$ Offgas Data.................................................... 


\section{LIST OF TABLES}

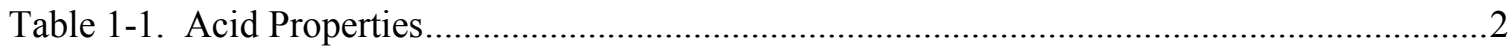

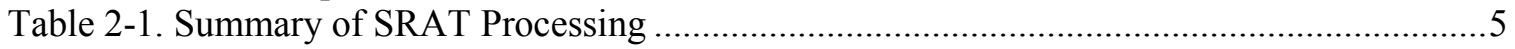

Table 2-2. MV I Rotor Specifications and Flow Curve Program.................................................

Table 3-1. Characterization Results and Acid Calculation Inputs of the SB5 Tank 51 (SC-13

SRAT Receipt) Sample with Added Neptunium ..............................................................

Table 3-2. Acid Calculation Inputs of the of the SB5 Tank 51 (SC-13 SRAT Receipt) Sample

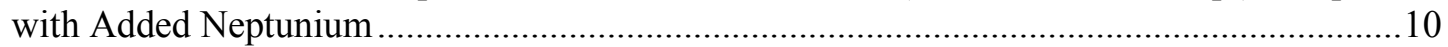

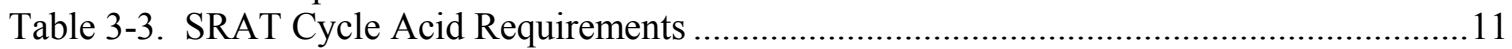

Table 3-4. SC-13 SRAT Product Characterization Results............................................................ 12

Table 3-5. Assumed and Measured Anion Destruction and Conversion in the SC-13 SRAT

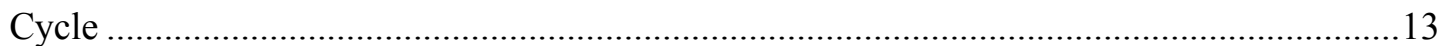

Table 3-6. Peak Offgas Generation in the SRAT Cycle, DWPF Scale .........................................13

Table 3-7. Solubility of Elements Measured by ICP-AES in SRAT Product ................................18

Table 3-8. Solubility of Mass as Measured by ICP-MS in SRAT Product ....................................18

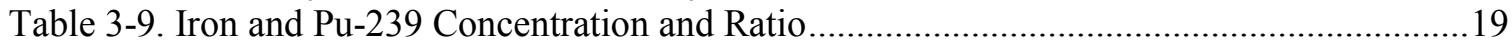

Table 3-10. Rheological Properties of As-Received and SRAT Product ....................................20

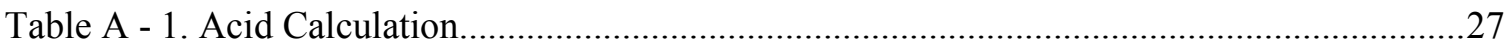

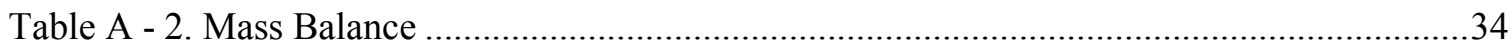

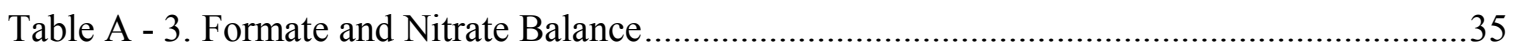

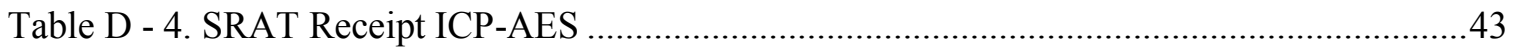

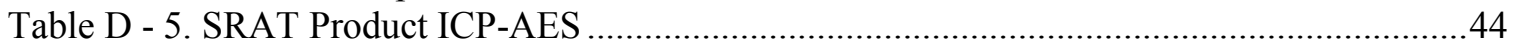

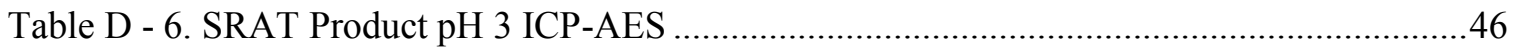

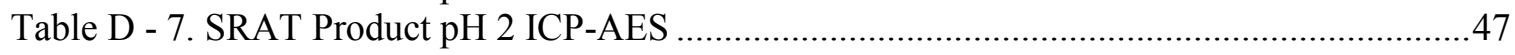

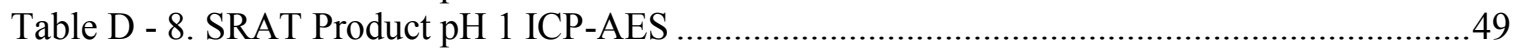

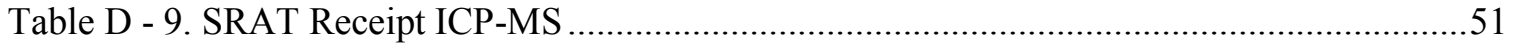

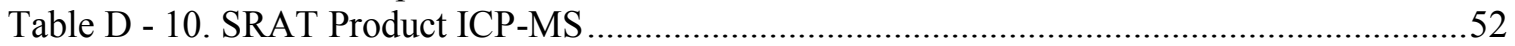

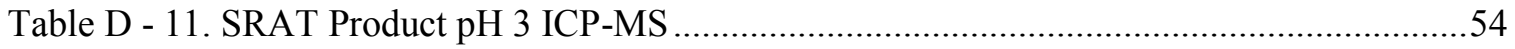

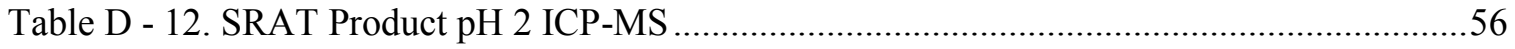

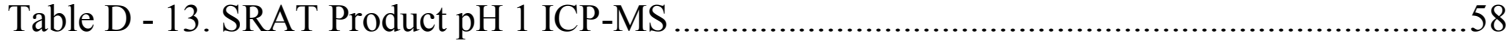




\section{LIST OF ACRONYMS}

$\begin{array}{ll}\text { ACTL } & \text { Aiken County Technologies Laboratory } \\ \text { AD } & \text { Analytical Development } \\ \text { ASP } & \text { Analytical Study Plan } \\ \text { CPC } & \text { Chemical Process Cell } \\ \text { DSA) } & \text { Documented Safety Analysis } \\ \text { DWPF } & \text { Defense Waste Processing Facility } \\ \text { FAVC } & \text { Formic Acid Vent Condenser } \\ \text { GC } & \text { Gas Chromatograph } \\ \text { HLW } & \text { High Level Waste } \\ \text { IC } & \text { Ion Chromatography } \\ \text { ICP-AES } & \text { Inductively Coupled Plasma - Atomic Emission Spectroscopy } \\ \text { ICP-MS } & \text { Inductively Coupled Plasma - Mass Spectroscopy } \\ \text { LDL } & \text { Less than Detectable Limit } \\ \text { LIMS } & \text { Laboratory Information Management System } \\ \text { MWWT } & \text { Mercury Water Wash Tank } \\ \text { NIST } & \text { National Institute of Standards and Testing } \\ \text { NM } & \text { Not Measured } \\ \text { PSAL } & \text { Process Science Analytical Laboratory } \\ \text { PSE } & \text { Process Science and Engineering Section } \\ \text { QA } & \text { Quality Assurance } \\ \text { REDOX } & \text { REDuction / OXidation potential } \\ \text { SB5 } & \text { Sludge Batch 5 } \\ \text { SB6 } & \text { Sludge Batch 6 } \\ \text { SC-7 } & \text { Shielded Cells Run 7 } \\ \text { SC-13 } & \text { Shielded Cells Run 13 } \\ \text { SEE } & \text { Systems Engineering Evaluation } \\ \text { SME } & \text { Slurry Mix Evaporator } \\ \text { SMECT } & \text { Slurry Mix Evaporator Condensate Tank } \\ \text { SRAT } & \text { Sludge Receipt and Adjustment Tank } \\ \text { SRNL } & \text { Savannah River National Laboratory } \\ \text { SRS } & \text { Savanna River Site } \\ \text { TIC } & \text { Total Inorganic Carbon } \\ \text { TOC } & \text { Total Organic Carbon } \\ \text { TS } & \text { Total Solids } \\ \text { TT\&QAP } & \text { Task Technical and Quality Assurance Plan } \\ \text { TTR } & \text { Waste Acceptance Criteria } \\ \text { WAC } & \text { WAPS } \\ & \end{array}$




\subsection{INTRODUCTION AND BACKGROUND}

Glycolic acid was effective at dissolving many metals, including iron, during processing with simulants. Criticality constraints take credit for the insolubility of iron during processing to prevent criticality of fissile materials. Testing with actual waste was needed to determine the extent of iron and fissile isotope dissolution during Chemical Process Cell (CPC) processing.

The Alternate Reductant Project was initiated by the Savannah River Remediation (SRR) Company to explore options for the replacement of the nitric-formic flowsheet used for the CPC at the Defense Waste Processing Facility (DWPF). The goals of the Alternate Reductant Project are to reduce CPC cycle time, increase mass throughput of the facility, and reduce operational hazards. In order to achieve these goals, several different reductants were considered during initial evaluations conducted by Savannah River National Laboratory (SRNL). After review of the reductants by SRR, SRNL, and Energy Solutions (ES) Vitreous State Laboratory (VSL), two flowsheets were further developed in parallel. The two flowsheet options included a nitric-formic-glycolic flowsheet, and a nitric-formic-sugar flowsheet.

As of July 2011, SRNL and ES/VSL have completed the initial flowsheet development work for the nitric-formic-glycolic flowsheet and nitric-formic-sugar flowsheet, respectively. On July $12^{\text {th }}$ and July $13^{\text {th }}$, SRR conducted a Systems Engineering Evaluation (SEE) ${ }^{1}$ to down select the alternate reductant flowsheet. The SEE team selected the Formic-Glycolic Flowsheet for further development. ${ }^{2}$

Two risks were identified in $\mathrm{SEE}^{1}$ for expedited research. The first risk is related to iron and plutonium solubility during the CPC process with respect to criticality. Currently, DWPF credits iron as a poison for the fissile components of the sludge. Due to the high iron solubility observed during the flowsheet demonstrations with simulants, it was necessary to determine if the plutonium in the radioactive sludge slurry demonstrated the same behavior. The second risk is related to potential downstream impacts of glycolate on Tank Farm processes. The downstream impacts will be evaluated by a separate research team.

Waste Solidification Engineering (WSE) has requested a radioactive demonstration of the GlycolicFormic Flowsheet with radioactive sludge slurry be completed in the Shielded Cells Facility of the $\mathrm{SRNL}^{3}$. The Shielded Cells demonstration only included a Sludge Receipt and Adjustment Tank (SRAT) cycle, and not a Slurry Mix Evaporator (SME) cycle or the co-processing of salt products. Sludge Batch 5 (SB5) slurry was used for the demonstration since it was readily available, had been previously characterized, and was generally representative of sludges being processing in DWPF. This sample was never used in the planned Shielded Cells Run 7 (SC-7).

This report documents:

- General processing parameters collected during a SRAT cycle,

- The solubility of iron and fissile isotopes for SRAT products with added nitric and glycolic acid to produce solutions at $\mathrm{pH} 3,2$, and 1 as worst case SRAT products, and

- Rheology of the SRAT product

This work is controlled by a Task Technical and Quality Assurance Plan (TTQAP) ${ }^{4}$, and analyses are guided by an Analytical Study Plan ${ }^{5}$. 


\subsection{Development of the Glycolic-Formic Flowsheet}

At the request of SRR, a study was completed evaluating 19 reductants to replace formic acid in CPC Processing $^{6}$. In the DWPF CPC, formic acid is both an acid and a reductant. Six reductants that are not acids were evaluated in addition to thirteen reducing acids. Glycolic acid was chosen based on this study. Since this initial study, all testing has been completed with glycolic acid, which like formic acid, is also both an acid and a reductant. Note that for every mole of glycolic acid added, two moles of carbon are added as glycolic acid is a two carbon organic acid. Glycolic acid mixed with formic acid was recommended to ensure mercury would be reduced even if glycolic acid was not effective in reducing mercury. ${ }^{6}$ Acid properties ${ }^{7}$ for glycolic and formic acid are listed in Table 1-1.

Table 1-1. Acid Properties

\begin{tabular}{|c|c|c|c|c|c|c|c|}
\hline Reductant & Formula & $\begin{array}{l}\text { Acid } \\
\text { pKa }\end{array}$ & $\begin{array}{l}\text { Solubility } \\
25 \mathrm{~g} \\
\mathrm{~g} / 100 \mathrm{ml}\end{array}$ & Molarity & $\begin{array}{l}\text { Typical Acid } \\
\text { Concentration }\end{array}$ & $\begin{array}{c}\text { Carbon } \\
\text { Oxidation } \\
\text { State }\end{array}$ & Structure \\
\hline $\begin{array}{l}\text { Formic } \\
\text { Acid }\end{array}$ & $\mathrm{CH}_{2} \mathrm{O}_{2}$ & 3.751 & Miscible & 23.6 & $90 \mathrm{wt} \%$ & 2 & \\
\hline $\begin{array}{l}\text { Glycolic } \\
\text { Acid }\end{array}$ & $\mathrm{C}_{2} \mathrm{H}_{4} \mathrm{O}_{3}$ & 3.831 & 80 & 11.83 & $71 \mathrm{wt} \%$ & 1 & \\
\hline
\end{tabular}

Due to the significant maintenance required for the DWPF Gas Chromatographs (GC) and the potential for production of flammable quantities of hydrogen, reducing the amount of formic acid used in the CPC is one of the options being considered. Earlier work at Savannah River National Laboratory has shown that replacing formic acid in the existing nitric/formic acid flowsheet with an 80:20 molar blend of glycolic and formic acids has the potential to remove mercury in the SRAT without any significant catalytic hydrogen generation. ${ }^{6}$

\subsection{Glycolic-Formic Flowsheet Testing with Simulants}

A total of twenty-two CPC simulations including SRAT and some SME cycles were performed to develop the flowsheet. ${ }^{8}$ The first four tests were a baseline nitric-formic flowsheet, a baseline GlycolicFormic Flowsheet, a run without mercury and a run with Actinide Removal Process (ARP) and Modular Caustic Side Solvent Extraction (MCU) streams added. The second set of four simulations included tests at varying acid stoichiometries to define the acid processing window and one test without any formic acid (nitric/glycolic acid only) to determine the effectiveness of glycolic acid as a reductant. No SME cycle was performed on the glycolic acid only flowsheet simulation ${ }^{9}$. Four tests were completed to produce products with a REDOX of $0-0.3$ to demonstrate REDOX control for this flowsheet. Four tests were completed at glycolic-formic acid blends of $40-70 \%$ glycolic acid to determine the iron solubility at varying glycolic acid blends. Lastly, two runs were completed without mercury and noble metals to determine the conditions for producing melter feed with the baseline and Glycolic-Formic Flowsheets.

A total of eight shortened SRAT cycles were performed to produce sufficient melter feed to test the Glycolic-Formic Flowsheets in the VSL DM10 melter. Approximately $100 \mathrm{~kg}$ (25 gallons) of SRAT product was produced for each flowsheet. No noble metals or mercury were added to the sludge in these experiments. The same simulant was used for each of these runs. ${ }^{10}$ 
SRNL-STI-2011-00622

Revision 0

In addition a total of ten SRAT cycles were performed with a sludge matrix to test the Glycolic-Formic Flowsheet ${ }^{11}$ over a wide sludge compositional range. Testing was done at both $100 \%$ and $150 \%$ stoichiometry. This was the first testing without the SB6H sludge simulant. 


\subsection{APPROACH}

\subsection{General Description of Analytical Methods}

Analyses for this task used guidance of an Analytical Study Plan (ASP). ${ }^{5}$ Sample request forms were used for samples to be analyzed, and analyses followed the guidelines and means of sample control stated in the ASP for the task. A unique laboratory identification management system (LIMS) number was assigned to each sample for tracking purposes. Analyses were performed using approved analytical and Quality Assurance (QA) procedures.

Procedures for analysis of the simulant material can be found in Reference 12 and 13. For the radioactive materials, procedures and work instructions for density, percent solids, and supernate and slurry dilutions are also given in Reference. For the radioactive materials, procedures and work instructions for density, percent solids, and supernate and slurry dilutions are also given in Reference 3. Procedures for digestions and sample analyses are given in Reference 4. It should be noted that the anion AD method was modified to add the analysis of glycolate. This method could not distinguish between the acetate and glycolate peaks. The anion results report a concentration of glycolate but this could also be acetate as these peaks overlap. The anion tables contain a note to explain the results. The glycolate anion result in the SRAT product sample is about 70 times higher than the glycolate concentration in the SRAT receipt sample as expected with the addition of glycolic acid.

Total base for the radioactive slurry was determined by a direct in-cell titration of slurry and a titration by SRNL Analytical Development (SRNL-AD) using diluted slurry.

\subsection{Chemical Process Cell (CPC) Processing (SRAT Cycle, SME Cycle)}

The SRAT cycle was conducted following procedures in the L29 procedure manual. ${ }^{14}$, After the SRAT cycle was complete and samples taken, the $\mathrm{pH}$ was adjusted to 3,2, and 1and samples were taken after each $\mathrm{pH}$ adjustment. A summary of the SRAT experimental work is presented in Table 2-1 below. 
Table 2-1. Summary of SRAT Processing

\begin{tabular}{|ll|}
\hline SRAT Cycle \\
\hline \hline - & Acid Calculation \\
- & Heating of SRAT Receipt to $93{ }^{\circ} \mathrm{C}$ \\
- & Addition of nitric, formic, and glycolic acids \\
- & Heat to boiling \\
- & Concentration (water removal) to a target $\mathbf{w t} \%$ total \\
& solids \\
- & Reflux for 12 hours \\
- & Cooldown \\
- & Sample \\
- & Add glycolic/formic acid to $\mathrm{pH} 3$ \\
- & Add nitric acid to $\mathrm{pH} 2$ \\
- & Sample \\
- & Add nitric acid to $\mathrm{pH} 1$ \\
- & Sample \\
\hline
\end{tabular}

Processing was performed using a vessel designed to process one liter of radioactive sludge. The SRAT rig was assembled and tested in the SRNL Shielded Cells Mockup area and placed into the Shielded Cells fully assembled. A detailed description of the SRAT rig and testing of the rigs can be found in Reference 15. The intent of the equipment is to functionally replicate the DWPF processing vessels. The glass kettle is used to replicate both the SRAT and the SME, and it is connected to the SRAT Condenser and the Mercury Water Wash Tank (MWWT). Because the DWPF Formic Acid Vent Condenser (FAVC) does not directly impact SRAT and SME chemistry, it is not included in SRNL Shielded Cells CPC processing. Instead, an electronic ice cube is used to cool offgas to approximately $20{ }^{\circ} \mathrm{C}$ below ambient to remove excess water before the gas reaches the gas chromatograph for characterization. The Slurry Mix Evaporator Condensate Tank (SMECT) is represented by a sampling bottle that is used to remove condensate through the MWWT. For the purposes of this report, the condensers and wash tank are referred to as the offgas components. A sketch of the experimental setup is given as Figure 2-1. 


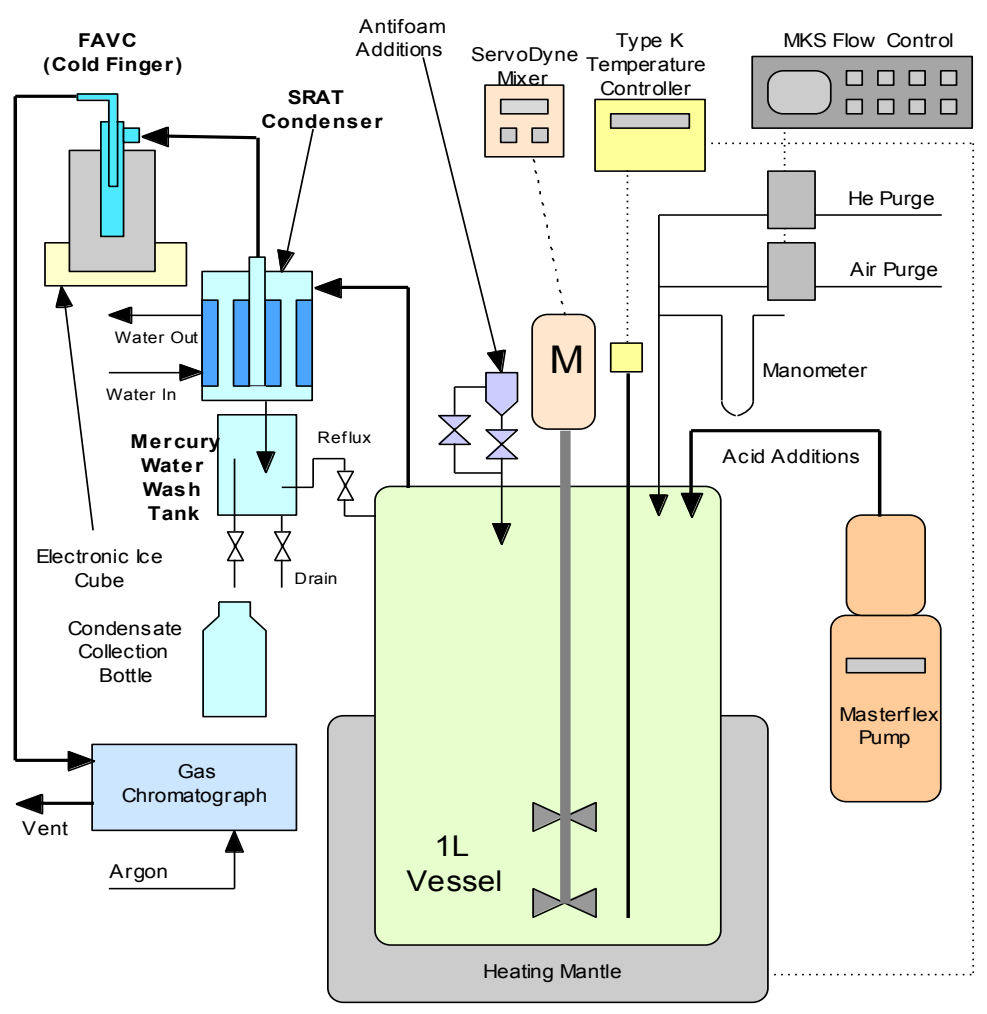

Figure 2-1. Schematic of SRAT Equipment Set-Up

SRAT processing parameters are summarized in Appendix A. In-line instrumentation was used to measure concentrations in the offgas system of the SRAT vessel and included helium, hydrogen, oxygen, nitrogen, nitrous oxide, and carbon dioxide. Helium was introduced at a concentration of $0.5 \%$ of the total air purge as an inert tracer gas, so that total amounts of generated gas and peak generation rates could be calculated. During the runs, the kettle was monitored to observe reactions that were occurring to include foaming, air entrainment, rheology changes, loss of heat transfer capabilities, and offgas carryover. Observations were recorded in a laboratory notebook ${ }^{16}$ and are discussed in Section 3.0.

Concentrated nitric acid (50-wt\%), and a blend of one mole of formic acid (90 wt \%) to four moles of glycolic acid (71 wt.\%) were used to acidify the sludge and perform neutralization and reduction reactions during processing. The amounts of acid to add for each run were determined using the existing DWPF acid addition equation ${ }^{17}$. The split of the acid was determined using the REDOX equation currently being used in DWPF processing ${ }^{18}$ with the addition of a glycolic acid term. To account for the reactions and anion destructions that occur during processing, assumptions about nitrite destruction, nitrite to nitrate conversion, and formate and glycolate destruction were made for each run. The values used for each run are provided in Section 3.0.

SRAT processing included the dewater time in boiling plus an additional time of reflux to simulate DWPF processing conditions. The SRAT condenser was maintained at $25{ }^{\circ} \mathrm{C}$ during the run, while the electronic ice cube condenser remained below $10{ }^{\circ} \mathrm{C}$. 


\subsection{Rheology}

Rheological properties were determined using a Haake M5/RV30 rotoviscometer. The M5/RV30 is a Searle sensor system, where the bob rotates and the cup is fixed. The torque and rotational speed of the bob are measured. Heating/cooling of the cup/sample/bob is through the cup holder. The shear stress is determined from the torque measurement and is independent of rheological properties. Conditions that impact the measured torque are; slip (material does not properly adhere to the rotor or cup), phase separation (buildup of liquid layer on rotor), sedimentation (particles settling out of the shearing zone), homogeneous sample (void of air), lack of sample (gap not filled), excess sample (primarily impacts rheologically thin fluids), completely filling up the void below the bob (air buffer that is now filled with fluid) and Taylor vortices. The first five items yield lower stresses and the last three add additional stresses.

The shear rate is geometrically determined using the equations of change (continuity \& motion) and is that for a Newtonian fluid. This assumption also assumes that the flow field is fully developed and the flow is laminar. The shear rate can be calculated for non-Newtonian fluid using the measured data and fitting this data to the rheological model or corrected as recommended by Darby ${ }^{12}$. In either case, for shear thinning non-Newtonian fluids, typical of Savannah River Site (SRS) sludge wastes, the corrected shear rates are greater than their corresponding Newtonian shear rates, resulting in a thinner fluid. The bob typically used for measuring tank sludge or SRAT product is the MV I rotor. The shape, dimensions, and geometric constants for the MV I rotor are provided in Table 2-2.

Prior to performing the measurements, the rotors and cups are inspected for physical damage. The torque/speed sensors and temperature bath are verified for functional operability using a bob/cup combination with a National Institute of Standards and Technology (NIST) traceable Newtonian oil standard, using the MV I rotor. The resulting flow curves are then fitted as a Newtonian fluid and this calculated viscosity must be within $\pm 10 \%$ of the reported NIST viscosity at a given temperature for the system to be considered functionally operable. A N10 oil standard was used to verify system operability prior to the sludge measurements. The flow curves for the sludge are fitted to the down curves using the Bingham Plastic rheological model, equation ${ }^{19}$, where $\tau$ is the measured stress $(\mathrm{Pa}), \tau_{\mathrm{o}}$ is the Bingham Plastic yield stress $(\mathrm{Pa}), \mu_{\infty}$ is the plastic viscosity $(\mathrm{Pa} \cdot \mathrm{sec})$, and $;$ is the measured shear rate $\left(\mathrm{sec}^{-1}\right)$.

During all these measurements, typically the sample remained in the cup for the $2^{\text {nd }}$ measurement, due to the sample available. If thixotropic properties or unique flow behavior were obvious on the first sample, efforts we made to perform additional measurements by reloading the sample.

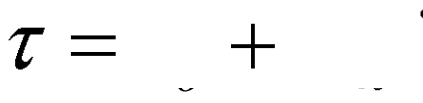


SRNL-STI-2011-00622

Revision 0

Table 2-2. MV I Rotor Specifications and Flow Curve Program

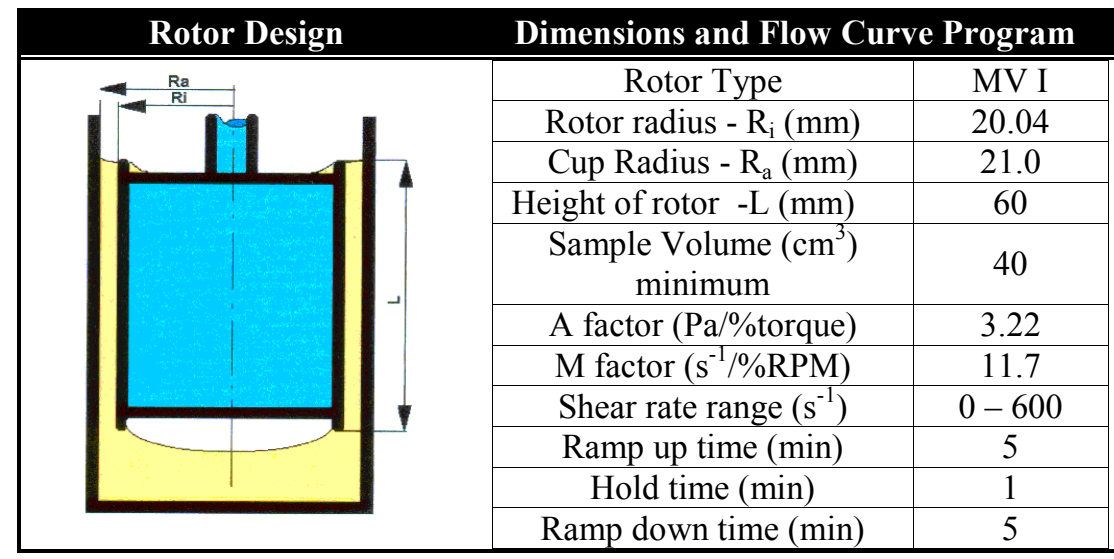




\subsection{RESULTS AND DISCUSSION}

\subsection{SRAT Receipt Characterization and Acid Addition Calculations}

The DWPF SRAT process relies upon use of the acid calculation to estimate the required acid necessary to complete reactions. This calculation relies upon measured analytical inputs. Errors in these measurements can result in too little acid being added resulting in incomplete reactions or too much acid being added resulting in excess hydrogen being generated. Therefore, the SB5 Tank 51 sample had been extensively characterized in 2008. The results of the Shielded Cells Run 13 (SC-13) SRAT receipt characterization are provided in Table 3-1. The sample was also reanalyzed after the run and the results are summarized in the "Post Run Analyses" column in Table 3-1. Table 3-2 gives the additional acid calculation inputs (e.g., formate destruction).

Table 3-1. Characterization Results and Acid Calculation Inputs of the SB5 Tank 51 (SC-13 SRAT Receipt) Sample with Added Neptunium

\begin{tabular}{|c|c|c|c|}
\hline Measurement & $\begin{array}{c}2008 \\
\text { Analyses }\end{array}$ & $\begin{array}{l}\text { Post Run } \\
\text { Analyses }\end{array}$ & Units \\
\hline Fresh Sludge Mass without trim chemicals & $1,140.0$ & $1,127.36$ & g slurry \\
\hline Fresh Sludge Weight \% Total Solids & 17.10 & 16.49 & $\mathrm{wt} \%$ \\
\hline Fresh Sludge Weight \% Calcined Solids & 13.40 & 12.70 & $\mathrm{wt} \%$ \\
\hline Fresh Sludge Weight \% Insoluble Solids & 10.97 & 10.72 & $\mathrm{wt} \%$ \\
\hline Fresh Sludge Density & 1.140 & 1.125 & kg / L slurry \\
\hline Fresh Sludge Supernate density & 1.059 & 1.056 & $\mathrm{~kg} / \mathrm{L}$ supernate \\
\hline Fresh Sludge Nitrite & 7,460 & 11,200 & $\mathrm{mg} / \mathrm{kg}$ slurry \\
\hline Fresh Sludge Nitrate & 14,500 & 8,760 & $\mathrm{mg} / \mathrm{kg}$ slurry \\
\hline Fresh Sludge Sulfate (mg/kg) & $\mathrm{N} / \mathrm{A}$ & 453 & $\mathrm{mg} / \mathrm{kg}$ slurry \\
\hline Fresh Sludge Chloride (mg/kg) & $\mathrm{N} / \mathrm{A}$ & $<161$ & $\mathrm{mg} / \mathrm{kg}$ slurry \\
\hline Fresh Sludge Phosphate (mg/kg) & $\mathrm{N} / \mathrm{A}$ & $<161$ & $\mathrm{mg} / \mathrm{kg}$ slurry \\
\hline Fresh Sludge Oxalate & $\mathrm{N} / \mathrm{A}$ & 444 & $\mathrm{mg} / \mathrm{kg}$ slurry \\
\hline Fresh Sludge Glycolate/Acetate\# & $\mathrm{N} / \mathrm{A}$ & $<161$ & $\mathrm{mg} / \mathrm{kg}$ slurry \\
\hline Fresh Sludge Slurry TIC (treated as carbonate) & 1,011 & 1,400 & $\mathrm{mg} / \mathrm{kg}$ slurry \\
\hline Fresh Supernate TIC (treated as carbonate) & 1,202 & 1,230 & $\mathrm{mg} / \mathrm{L}$ supernate \\
\hline Fresh Sludge Hydroxide (Base Equivalents) pH $=7$ & 0.5548 & 0.5680 & $\begin{array}{l}\text { Eq Moles Base/L } \\
\text { slurry }\end{array}$ \\
\hline Fresh Sludge Manganese (\% of Calcined Solids) & 4.844 & 4.33 & wt $\%$ calcined basis \\
\hline Fresh Sludge Mercury (\% of Total Solids) & 1.94 & NM & wt $\%$ dry basis \\
\hline Fresh Sludge Magnesium (\% of Calcined Solids) & 0.727 & 0.709 & wt $\%$ calcined basis \\
\hline Fresh Sludge Sodium (\% of Calcined Solids) & 19.2 & 18.8 & wt $\%$ calcined basis \\
\hline Fresh Sludge Potassium (\% of Calcined Solids) & 0.079 & $<0.065$ & wt $\%$ calcined basis \\
\hline Fresh Sludge Calcium (\% of Calcined Solids) & 1.53 & 1.56 & wt $\%$ calcined basis \\
\hline Fresh Sludge Strontium (\% of Calcined Solids) & $\mathrm{N} / \mathrm{A}$ & $<0.064$ & wt $\%$ calcined basis \\
\hline Fresh Sludge Nickel (\% of Calcined Solids) & 2.71 & 2.95 & wt $\%$ calcined basis \\
\hline Fresh Sludge Supernate Manganese & $\mathrm{N} / \mathrm{A}$ & $<1.021$ & $\mathrm{mg} / \mathrm{L}$ supernate \\
\hline
\end{tabular}

\# The method used did not separate the glycolate and acetate peaks. $<161 \mathrm{mg} / \mathrm{kg}$ glycolate-acetate in the SRAT receipt sample may have been $<161 \mathrm{mg} / \mathrm{kg}$ glycolate or $<155 \mathrm{mg} / \mathrm{kg}$ acetate or any combination of the two that would give a peak of $<161 \mathrm{mg} / \mathrm{kg}$ glycolate). 
The SRAT cycle acid calculation utilizes the amount of nitrite, mercury, manganese, carbonate, and base equivalents to calculate the stoichiometric amount of acid to be added. Nitric acid, glycolic acid and formic acid amounts are calculated based on the applied stoichiometric factor and the ratio needed to achieve the target glass REDOX $\left(\mathrm{Fe}^{+2} / \Sigma \mathrm{Fe}\right)$. The equation for prediction of glass REDOX utilizes estimates of the amount of glycolate, formate, oxalate, nitrate, nitrite, manganese, and total solids in the SME product. A modified REDOX equation was used in these calculations with the addition of the glycolate term with a factor of 6 .

The REDOX prediction equation used in this study with an added term for glycolate is ${ }^{18}$ :

$\mathrm{Fe}^{2+} / \mathrm{Fe}=0.2358+0.1999 *(2[\mathrm{~F}]+4[\mathrm{C}]+6[\mathrm{G}]+4[\mathrm{OT}]+5[\mathrm{~N}]-5[\mathrm{Mn}]) 45 / \mathrm{T}$

Where $\quad[\mathrm{F}]=$ formate $(\mathrm{mol} / \mathrm{kg}$ feed $)$

$[\mathrm{C}]=\operatorname{coal}($ carbon $)(\mathrm{mol} / \mathrm{kg}$ feed $)$

$[\mathrm{G}]=$ glycolate $(\mathrm{mol} / \mathrm{kg}$ feed $)$

$[\mathrm{OT}]=$ oxalate Total (soluble and insoluble) $(\mathrm{mol} / \mathrm{kg}$ feed $)$

$[\mathrm{N}]=$ nitrate + nitrite $(\mathrm{mol} / \mathrm{kg}$ feed $)$

$[\mathrm{Mn}]=$ manganese $(\mathrm{mol} / \mathrm{kg}$ feed $)$

$\mathrm{T}=$ Total Solids, wt $\%$

The estimation of the final concentration for the anions requires assumptions to be made concerning how these species will react during the SRAT and SME cycles. Glycolate, formate and oxalate are destroyed by reactions with oxidizing species, and formate is destroyed by noble metal-catalyzed reactions. Nitrite is typically consumed during acid additions, but can react to form different species including nitrate. Inputs for the SC-13 run are based on simulant studies. ${ }^{8}$ The acid calculation inputs and assumptions are shown in Table 3-1 and Table 3-2.

Table 3-2. Acid Calculation Inputs of the of the SB5 Tank 51 (SC-13 SRAT Receipt) Sample with Added Neptunium

\begin{tabular}{|l|c|l|}
\hline Processing Assumptions & Predicted & Units \\
\hline Conversion of Nitrite to Nitrate in SRAT Cycle & 0.00 & gmol $\mathrm{NO}_{3} / 100{\text { gmol } \mathrm{NO}_{2}}^{-}$ \\
\hline Destruction of Nitrite in SRAT and SME cycle & 100 & $\%$ of starting nitrite destroyed \\
\hline Destruction of Formic acid charged in SRAT & 90 & $\%$ formate converted to $\mathrm{CO}_{2}$ etc. \\
\hline Destruction of Glycolic acid charged in SRAT & 0.00 & $\%$ glycolate converted to $\mathrm{CO}_{2}$ etc. \\
\hline Conversion of Glycolic acid to Oxalate & 3.00 & $\%$ glycolate converted to $\mathrm{C}_{2} \mathrm{O}_{4}$ \\
\hline Destruction of Oxalate charged & 0.00 & $\%$ of total oxalate destroyed \\
\hline Percent Acid in Excess Stoichiometric Ratio & 110 & $\%$ \\
\hline SRAT Product Target Solids & 25. & $\%$ \\
\hline Nitric Acid Molarity & 10.200 & Molar \\
\hline Formic Acid Molarity & 23.537 & Molar \\
\hline Glycolic Acid Molarity & 11.826 & Molar \\
\hline DWPF Nitric Acid addition Rate & 2.0 & gallons per minute \\
\hline DWPF Formic Acid addition Rate & 2.0 & gallons per minute \\
\hline REDOX Target & 0.100 & $\mathrm{Fe}^{+2} / \Sigma \mathrm{Fe}$ \\
\hline
\end{tabular}

The acid calculation determines the values for a large number of processing parameters as well as the amount of acid to be used. Acid requirements (per liter of SRAT receipt) are shown in Table 3-3 with all values tabulated in Appendix A. 
Table 3-3. SRAT Cycle Acid Requirements

\begin{tabular}{|l|c|}
\hline Run ID & SC-13 \\
\hline Koopman Stoichiometry. Acid, moles/L & 1.21 \\
\hline Hsu Stoichiometry. Acid, moles/L & 1.07 \\
\hline Actual Acid Added, moles/L & 1.334 \\
\hline Ratio of Reducing Acid to Total Acid & 0.600 \\
\hline Moles glycolic/moles total acid in glycolic/formic acid Blend & 0.800 \\
\hline
\end{tabular}

\subsection{CPC Processing Results}

The run was completed as planned, with the exception that the $\mathrm{pH}$ probe had a loose connection in the cells leading to erroneous readings throughout the SRAT cycle, and the acid pump did not work and had to be replaced. The $\mathrm{pH}$ probe was replaced, and a different electrical connection was used after the SRAT cycle to acidify the SRAT product to a $\mathrm{pH}$ of 3,2 and 1. The acid pump was replaced with a single speed pump so the addition rate could not be controlled. The acid pump added acid at $0.20 \mathrm{ml} / \mathrm{min}$, instead of the $0.34 \mathrm{ml} / \mathrm{min}$ planned for nitric acid and the $0.69 \mathrm{ml} / \mathrm{min}$ planned for the glycolic-formic acid blend. DWPF acid adds both nitric and formic acid at 2 gallons $/ \mathrm{min}$, which is scaled to $0.34 \mathrm{~mL} / \mathrm{min}$ for Shielded Cell's experiments. This extended the time of the acid addition and especially the time for the water flush of the acid line extended the time at $93^{\circ} \mathrm{C}$. DWPF typically adds formic acid at 1 gallon per minute $(0.17 \mathrm{ml} / \mathrm{min}$ scaled $)$, so the addition rate of the glycolic-formic acid blend was higher than the formic acid is typically added in DWPF. The higher addition rates were planned to add the glycolicformic acid blend at the same molar flowrate as the design basis for formic acid, which would cut the glycolic-formic acid blend addition time in half. The slower addition of acid mainly lowers the offgas peaks and increases the time when the offgas is being produced. The main impact of this strategy is to minimize foam generation rate, which may minimize foam volume during acid addition.

One interesting note is the glassware was much cleaner in the Glycolic-Formic Flowsheet demonstration. For example, the original $\mathrm{pH}$ probe was very clean when removed (it was expected to be sludge coated and broken) as were the agitator and thermocouple. In addition, the glassware was clean enough that the cell wall could be seen through the vessel back "window".

\subsubsection{SRAT Cycle Processing Observations}

No significant processing problems occurred during the SC-13 SRAT cycle other than minimal foaming. No difficulties in mixing or heating the sludge slurry were experienced, but the agitation was increased from $400 \mathrm{rpm}$ to $600 \mathrm{rpm}$ compared to earlier shielded cells runs to maintain adequate mixing. The newest batch of antifoam (Lot\# 111128-0613), based on the revised antifoam purchase specification was used. The following was the antifoam addition strategy:

- $200 \mathrm{ppm}$ addition prior to starting the cycle

- 100 ppm addition between nitric and formic/glycolic acid additions

- $500 \mathrm{ppm}$ addition after acid addition, prior to boiling

- 100 ppm addition every 8 hours thereafter

No apparent mercury collected in the MWWT. Black deposits were evident in the tubing between the condenser and MWWT. In simulant runs with higher chloride or iodine, there are more black deposits and less elemental mercury collected. No chloride was detected in the SRAT receipt sample. The 
measured mercury in the SRAT receipt sample was $1.94 \mathrm{wt} \%$ (0.018 g-moles). No chloride was detected in any of the SRAT product supernate and slurry samples.

\subsubsection{SRAT Cycle Sample Results}

A sample was pulled at the conclusion of the SRAT cycle. The total solids, anions, and mercury analysis were performed. These results are presented in Table 3-4. As shown in the table, nitrite was adequately destroyed, and mercury was removed below $0.8 \mathrm{wt} . \%$ of total solids.

Table 3-4. SC-13 SRAT Product Characterization Results

\begin{tabular}{|l|c|c|c|c|}
\multicolumn{2}{|c|}{$\begin{array}{c}\text { SRAT } \\
\text { Wt \% Total Solids (slurry basis) }\end{array}$} & $\begin{array}{c}\text { Adjusted to } \\
\mathrm{pH} \mathrm{3}\end{array}$ & $\begin{array}{c}\text { Adjusted to } \\
\mathrm{pH} 2\end{array}$ & $\begin{array}{c}\text { Adjusted to } \\
\mathrm{pH} 1\end{array}$ \\
\hline Wt \% Insoluble Solids (slurry basis) & $24.30 \%$ & $25.70 \%$ & $25.70 \%$ & $24.66 \%$ \\
\hline Wt \% Soluble Solids (slurry basis) & $13.07 \%$ & $12.56 \%$ & $12.71 \%$ & $11.86 \%$ \\
\hline Wt \% Supernate Solids (supernate basis) & $11.23 \%$ & $13.14 \%$ & $12.99 \%$ & $12.80 \%$ \\
\hline Wt \% Calcined Solids (slurry basis) & $14.84 \%$ & $17.68 \%$ & $17.48 \%$ & $16.99 \%$ \\
\hline Slurry Density (g/mL) & $14.81 \%$ & $14.70 \%$ & $14.26 \%$ & $13.55 \%$ \\
\hline Supernate Density (g/mL) & 1.205 & 1.215 & 1.218 & 1.221 \\
\hline Fluoride & 1.119 & 1.132 & 1.140 & 1.148 \\
\hline Glycolate (Acetate)\# & $<328$ & $<325$ & $<321$ & $<309$ \\
\hline Formate & 42,600 & 48,300 & 46,600 & 45,500 \\
\hline Chloride & 3,540 & 4,620 & 4,120 & 3,730 \\
\hline Nitrite & $<164$ & $<325$ & $<321$ & $<309$ \\
\hline Bromide & 426 & $<325$ & $<321$ & $<309$ \\
\hline Nitrate & $<164$ & $<325$ & $<321$ & $<309$ \\
\hline Phosphate & 52,890 & 68,230 & 82,330 & 98,200 \\
\hline Sulfate & $<164$ & $<325$ & $<321$ & $<309$ \\
\hline Oxalate & 426 & 397 & 393 & 407 \\
\hline \hline Mercury (wt \% of total solids) & 434 & 1,190 & 1,190 & 1,810 \\
\hline
\end{tabular}

\# The method used did not separate the glycolate and acetate peaks.

\subsubsection{SRAT Cycle Anion Destruction and Conversion}

Inputs to the acid calculation include formate, glycolate and nitrite destruction and conversion of nitrite to nitrate. Presented in Table 3-5 is a comparison between these assumed values (based on simulant runs) and measured results. As can be seen in the table, glycolate destruction and nitrite to nitrate conversion were higher than predicted. This means that more nitrate and less glycolate were present in the SRAT product. The predicted REDOX of the SRAT product, based on anion measurements, was $0.05 \mathrm{Fe}^{+2} / \sum \mathrm{Fe}$ instead of the targeted $0.10 \mathrm{Fe}^{+2} / \sum \mathrm{Fe}$. The agreement between assumed and measured destruction is adequate as no simulant runs had been completed at the same acid stoichiometry, mercury or noble metals targets as is generally completed before a shielded cells demonstration. 
SRNL-STI-2011-00622

Revision 0

Table 3-5. Assumed and Measured Anion Destruction and Conversion in the SC-13 SRAT Cycle

\begin{tabular}{|l|c|c|}
\hline Anion Conversion & Assumed & Measured \\
\hline Nitrite Destruction (\%) & 100 & 94.9 \\
\hline Formate Destruction (\%) & 90.0 & 90.2 \\
\hline Glycolate Destruction (\%) & 3.0 & 17.7 \\
\hline Nitrite to Nitrate Conversion (\%) & 0.0 & 35.2 \\
\hline
\end{tabular}

\subsubsection{SRAT Cycle Offgas Analysis}

Offgas data for the SC-13 SRAT cycle are presented in the following figures. The peak generation rates (lb/hr DWPF-Scale) are summarized in Table 3-6. No catalytic hydrogen was detected throughout the SRAT cycle. The detection limit for hydrogen is 0.001 volume $\%$. The $\mathrm{N}_{2} \mathrm{O}$ and $\mathrm{CO}_{2}$ generation rates are significantly lower than have been seen in nitric-formic flowsheet runs.

Table 3-6. Peak Offgas Generation in the SRAT Cycle, DWPF Scale

\begin{tabular}{|l|l|}
\hline $\mathbf{G a s}$ & $\mathbf{l b} / \mathbf{h r}$ \\
\hline $\mathbf{N}_{\mathbf{2}} \mathbf{O}$ & 3.63 \\
\hline $\mathbf{C} \mathbf{O}_{\mathbf{2}}$ & 115 \\
\hline $\mathbf{H}_{\mathbf{2}}{ }^{*}$ & $<0.001$ \\
\hline
\end{tabular}

* Hydrogen detection limit approximately 0.001 volume \% 
SRNL-STI-2011-00622

Revision 0

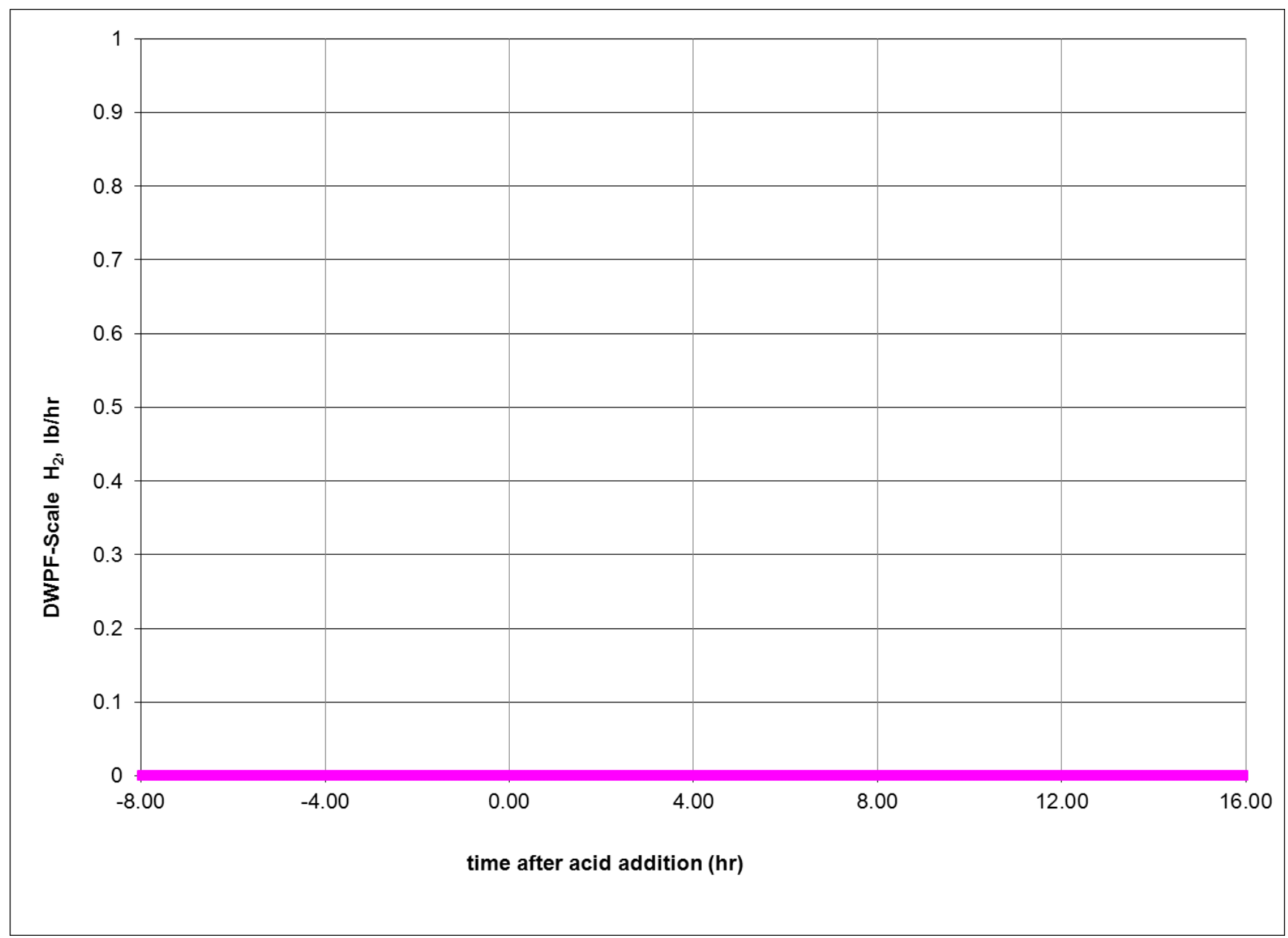

Figure 3-1. Hydrogen Generation during SC-13 SRAT Cycle 
SRNL-STI-2011-00622

Revision 0

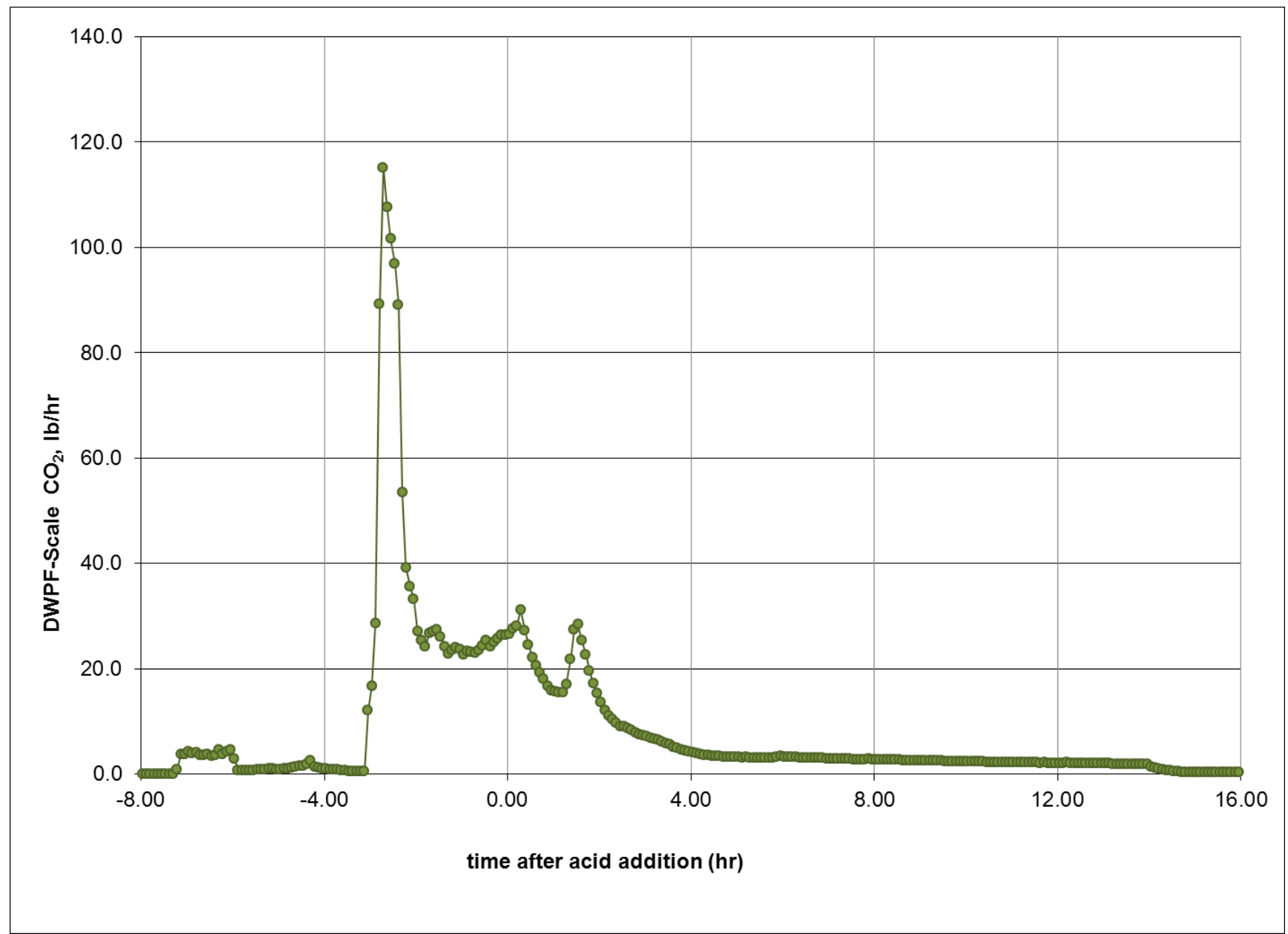

Figure 3-2. Carbon Dioxide Generation during SC-13 SRAT Cycle 
SRNL-STI-2011-00622

Revision 0

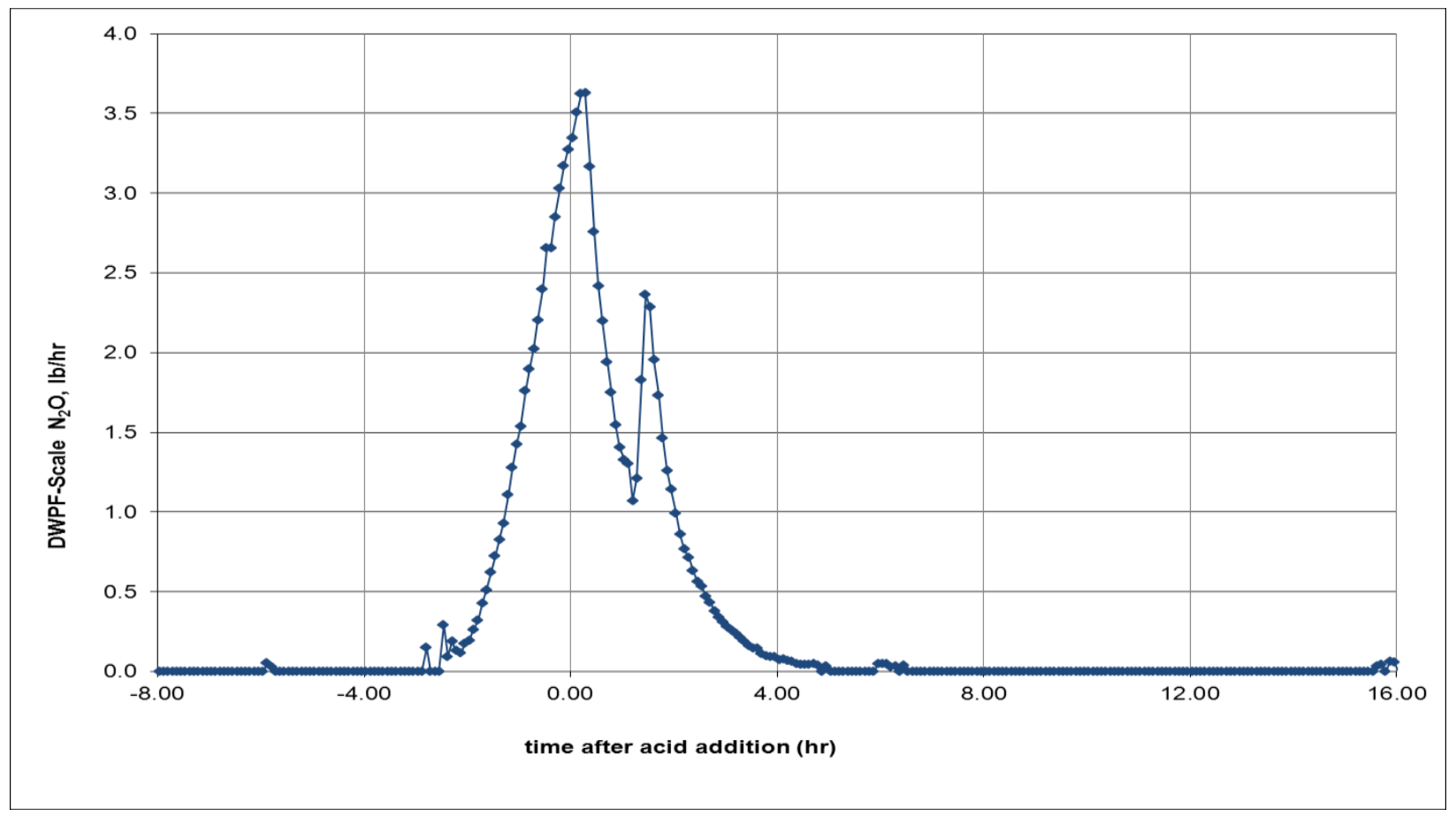

Figure 3-3. Nitrous Oxide Generation during SC-13 SRAT Cycle

\subsection{Iron and Fissile Solubility}

DWPF credits iron as a poison for the fissile components of the sludge. Iron and the fissile isotopes such as Pu-239 are typically both fairly insoluble throughout CPC processing. However, in testing with simulated sludge and the formic-glycolic flowsheet, a significant fraction of the iron became soluble in CPC processing, increasing from 3\% at an acid stoichiometry of 100\% (Simulant Run GF6) to 65\% at an acid stoichiometry of $200 \%$ (Simulant Run GF7) as summarized in Figure 3-4. Due to the iron solubility observed during the flowsheet demonstrations with sludge simulant, it was necessary to determine if the $\mathrm{Fe}$ and fissile isotopes in the actual waste demonstrated the same solubility behavior. 
SRNL-STI-2011-00622

Revision 0

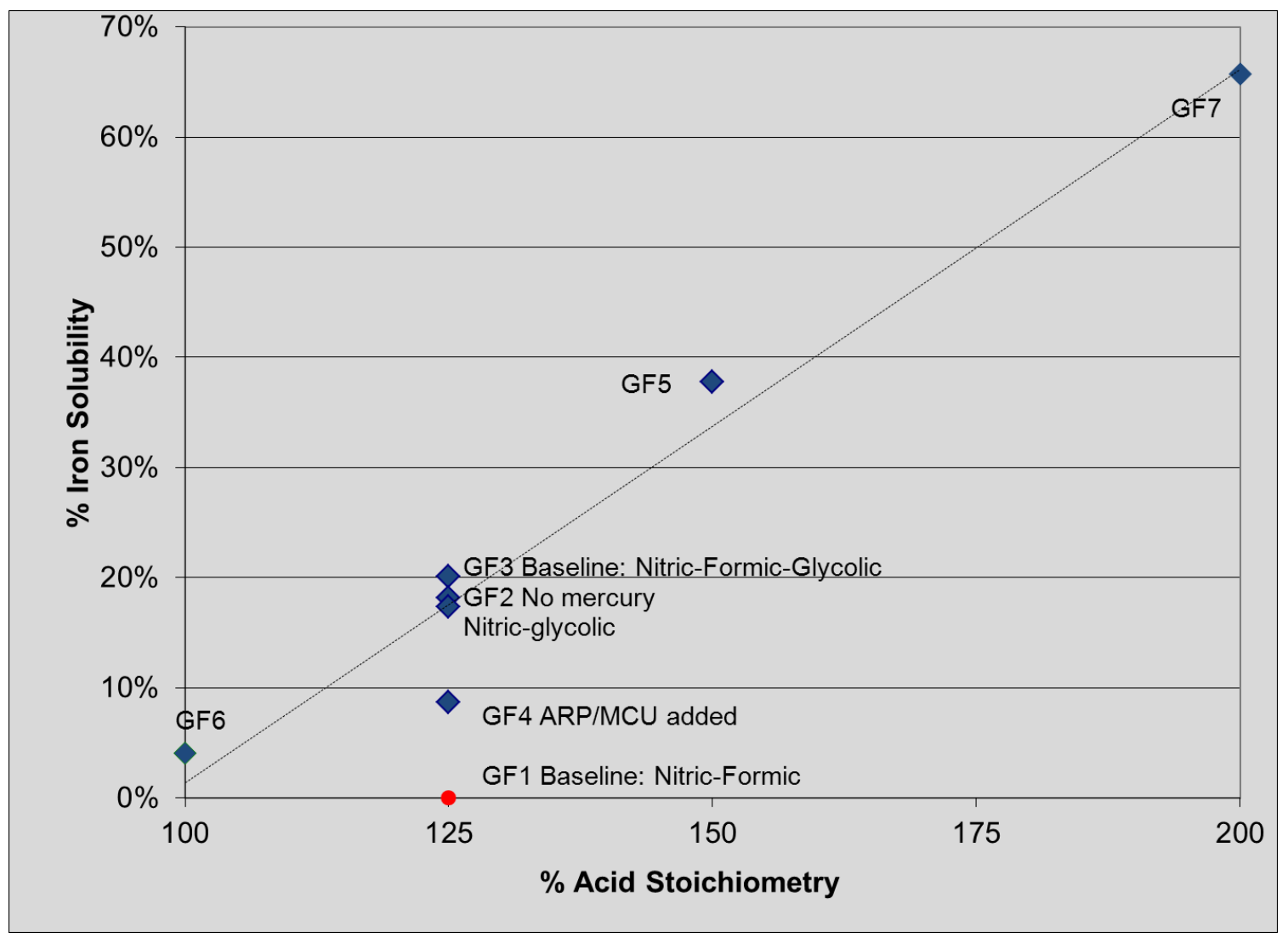

Figure 3-4. Iron Solubility as a Function of Acid Stoichiometry in Simulant Runs

Four SRAT product samples were prepared by the addition of both nitric and glycolic-formic acid. The SRAT product had a $\mathrm{pH}$ of 6 . After all SRAT product samples were collected, the glycolic/formic acid mixture was added to the remaining SRAT product until the $\mathrm{pH}$ remained steady (both acids act as buffers, typically at a $\mathrm{pH}$ of 3.75 for formic acid and 3.83 for glycolic acid). The addition of $50 \mathrm{wt} \%$ nitric was used to bring the $\mathrm{pH}$ down to the final $\mathrm{pH}$ targets of 3,2 and 1 . Note that the SRAT product $\mathrm{pH}$ stayed at $\mathrm{pH} 4.2$ until nitric acid was added. Therefore during normal processing, the $\mathrm{pH}$ will not drop below 4 so these solutions are very conservative from a pH standpoint.

The solubility of a number of elements in the SRAT products at $\mathrm{pH}$ 6, 3, 2 and 1 are summarized in Table 3 -7. Iron has a very low solubility in the SRAT receipt sample $(2.2 \%$ in the SRAT product at $\mathrm{pH} 1)$ in the Glycolic-Formic Flowsheet as is the case with the nitric-formic-glycolic flowsheet. The fissile masses had significantly higher solubilities than iron in all testing. For example, the mass 239 solubility peak was $27.6 \%$, higher than iron. The solubility of the masses from ICP-MS data are summarized in Table 3-8. 
Table 3-7. Solubility of Elements Measured by ICP-AES in SRAT Product

\begin{tabular}{|c|c|c|c|c|c|}
\hline \multirow[t]{2}{*}{ Element } & \multirow{2}{*}{$\begin{array}{l}\text { SRAT } \\
\text { Receipt }\end{array}$} & \multicolumn{4}{|c|}{$\%$ Solubility of SRAT Product } \\
\hline & & pH 6 & pH 3 & pH 2 & pH 1 \\
\hline Al & 10.1 & 3.36 & 7.89 & 10.2 & 10.3 \\
\hline $\mathbf{F e}$ & 0.0024 & 0.600 & 1.56 & 2.20 & 2.22 \\
\hline Gd & 2.38 & 32.3 & 66.6 & 67.5 & 67.8 \\
\hline $\mathbf{M g}$ & 0.0287 & $\overline{55.8}$ & 63.6 & 65.6 & 65.1 \\
\hline Mn & 0.0166 & 46.3 & 55.7 & 56.9 & 57.1 \\
\hline $\mathbf{N a}$ & 87.1 & 92.9 & 93.6 & 96.1 & 95.2 \\
\hline $\mathbf{N i}$ & 0.209 & 7.56 & 10.70 & 12.1 & 12.0 \\
\hline $\mathbf{S}$ & 69.5 & 78.6 & LDL* & 50.5 & 54.5 \\
\hline$\overline{\mathbf{U}}$ & 0.706 & 30.5 & 71.9 & 71.6 & 78.1 \\
\hline
\end{tabular}

Table 3-8. Solubility of Mass as Measured by ICP-MS in SRAT Product

\begin{tabular}{|l|c|r|r|r|r|}
\hline Element or & \multicolumn{4}{c}{ SRAT } & \multicolumn{4}{c|}{ \% Solubility of SRAT Product } \\
Isotope & Receipt & pH 6 & pH 3 & pH 2 & pH 1 \\
\hline La (139) & LDL & 14.6 & 30.5 & 35.0 & 33.9 \\
\hline $\begin{array}{l}\text { Nd (143-46, } \\
\mathbf{1 4 8 , 1 5 0 )}\end{array}$ & LDL & 16.9 & 34.5 & 36.1 & 32.8 \\
\hline $\begin{array}{l}\text { Gd (155-58, } \\
\mathbf{1 6 0 )}\end{array}$ & LDL & 30.7 & 65.8 & 63.7 & 51.4 \\
\hline U (235,238) & $5.73 E-3$ & 30.3 & 81.2 & 67.3 & 51.5 \\
\hline Pu (239) & LDL & 7.65 & 27.6 & 27.4 & 18.9 \\
\hline Np (237) & LDL & 40.8 & 62.5 & 61.2 & 69.1 \\
\hline
\end{tabular}

The mass ratio of iron to $\mathrm{Pu}-239$ is summarized in Table 3-9. A number of other ratios important to criticality are also summarized in Table 3-9. For example, the minimum Fe:Pu-239 ratio was 383, approximately 2.4 times the current DWPF limit. The minimum $\mathrm{Mn}: \mathrm{Pu}-239$ ratio was 90.3 , greater than the 29:1 limit. ${ }^{20}$ Also, the concentration of ${ }^{239} \mathrm{Pu}\left(\mathrm{NO}_{3}\right)_{4}$ in the supernate was far below the $7.3 \mathrm{~g} / \mathrm{L}$ limit specified by the ANS regulation for nuclear criticality safety in operations with fissionable material outside reactors ${ }^{21}$.

In the future, sludge batches enriched in uranium (i.e., greater than $0.93 \mathrm{wt} \%$ in U-235) may be processed at DWPF. Currently, sludge batches are blended less than or equal to $0.93 \mathrm{wt} \% \mathrm{U}-235$ to ensure the uranium stays subcritical during DWPF processing. If a sludge batch were prepared that exceeded the current $0.93 \mathrm{wt} \%$ Documented Safety Analysis (DSA) / Waste Acceptance Criteria (WAC) requirement, then crediting another neutron poison may be desired. Manganese could serve as a neutron poison for the U-235 due to their similar chemistries under caustic and acidic conditions. It should be noted in Table 39 that all SRAT Products ( $\mathrm{pH}$ of 6 to 1 ) exceeded the $\mathrm{Mn}: \mathrm{Pu}-239$ safe weight ratio of 29:1. ${ }^{20}$ 
SRNL-STI-2011-00622

Revision 0

Table 3-9. Iron, Manganese and Pu-239 Concentration and Ratio (Slurry Basis unless noted)

\begin{tabular}{|c|c|c|c|c|c|c|}
\hline \multirow{2}{*}{$\begin{array}{c}\text { Element or Isotope } \\
\text { or Ratio }\end{array}$} & \multirow[t]{2}{*}{ Limit } & \multirow{2}{*}{$\begin{array}{c}\text { SRAT } \\
\text { Receipt }\end{array}$} & \multicolumn{4}{|c|}{ SRAT Product } \\
\hline & & & pH 6 & pH 3 & pH 2 & pH 1 \\
\hline Slurry Iron, mg/kg & NA & 23,800 & 28,100 & 26,600 & 25,200 & 25,000 \\
\hline Filtrate Iron, $\mathrm{mg} / \mathrm{kg}$ & NA & 0.581 & 169 & 415 & 551 & 555 \\
\hline $\begin{array}{c}\text { Slurry Manganese, } \\
\mathrm{mg} / \mathrm{kg}\end{array}$ & NA & 5,505 & 6,643 & 6,360 & 6,140 & 5,893 \\
\hline $\begin{array}{c}\text { Slurry Pu-239, } \\
\text { mg/kg }\end{array}$ & NA & 55.1 & 60.9 & 59.3 & 62.6 & 65.3 \\
\hline $\begin{array}{c}\text { Filtrate Pu-239, } \\
\mathrm{mg} / \mathrm{kg}\end{array}$ & NA & 0.0265 & 15.1 & 18.5 & 16.4 & 6.79 \\
\hline $\begin{array}{c}\text { Fe:Pu-239 ratio in } \\
\text { slurry }\end{array}$ & $\geq 160$ & 432 & 462 & 449 & 402 & 383 \\
\hline $\begin{array}{c}\text { Fe:Pu-239 ratio in } \\
\text { filtrate }\end{array}$ & NA & 21.9 & 11.2 & 22.4 & 33.6 & 81.8 \\
\hline $\begin{array}{c}\text { Mn:Pu-239 ratio in } \\
\text { slurry }\end{array}$ & $\geq 29$ & 100 & 109 & 107 & 98.0 & 90.3 \\
\hline $\begin{array}{c}{ }^{239} \mathrm{Pu}\left(\mathrm{NO}_{3}\right) 4 \mathrm{~g} / \mathrm{L} \\
\text { filtrate basis }\end{array}$ & $\leq 7.3$ & $\begin{array}{l}<6.40 \mathrm{E}- \\
5 \\
\end{array}$ & 0.0122 & 0.0432 & 0.0493 & 0.0327 \\
\hline
\end{tabular}

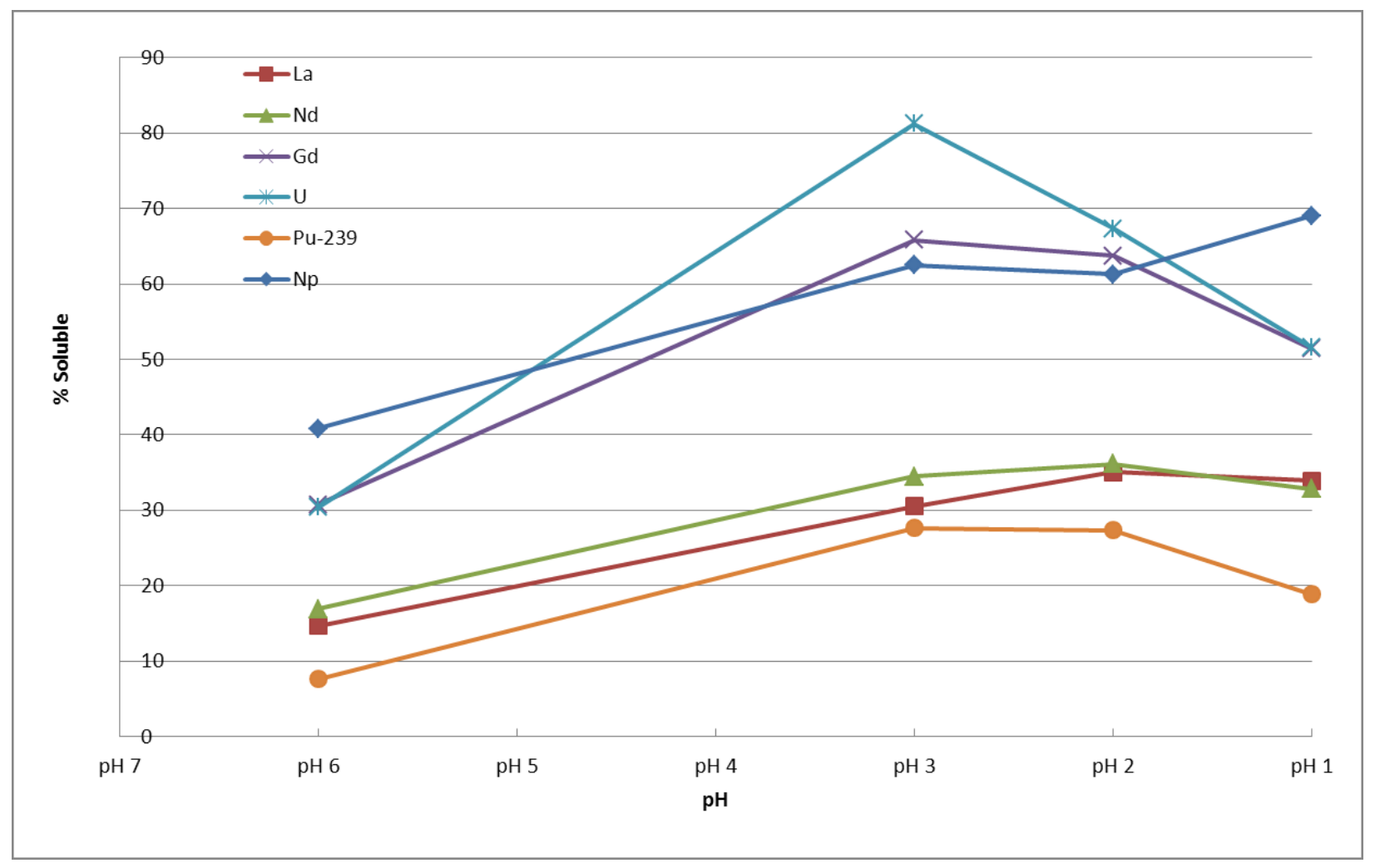

Figure 3-5. Element Solubility from ICP-MS as a Function of pH 


\subsection{Rheology}

The rheological properties, solids and density data are summarized in Table 3-10. Rheology was measured on two of the SRAT products. There was no yield stress so the slurry was Newtonian.

Table 3-10. Rheological Properties of As-Received and SRAT Product

\begin{tabular}{|l|c|c|c|c|c|}
\multicolumn{1}{|c}{ Sample } & \multicolumn{1}{c}{$\begin{array}{c}\text { Yield Stress } \\
(\mathrm{Pa})\end{array}$} & $\begin{array}{c}\text { Plastic } \\
\text { Viscosity }(\mathrm{CP})\end{array}$ & $\begin{array}{c}\text { Wt\% Total } \\
\text { Solids }\end{array}$ & $\begin{array}{c}\text { Wt\% } \\
\text { Insoluble } \\
\text { Solids }\end{array}$ & $\begin{array}{c}\text { Slurry } \\
\text { Density } \\
(\mathrm{g} / \mathrm{ml})\end{array}$ \\
\hline SC-13 SRAT Product & 0.20 & 6.70 & 24.3 & 13.07 & 1.205 \\
\hline SC-13 SRAT Product $\mathrm{pH} 2$ & 0 & 6.13 & 25.7 & 12.71 & 1.218 \\
\hline
\end{tabular}

\subsection{REDOX}

No SME cycle was completed during this testing. Insufficient SRAT product was available to measure REDOX. It is recommended that a SRAT/SME cycle demonstration should be completed using actual waste to demonstrate the entire flowsheet. Utilize the SME product to produce glass and measure resulting glass REDOX potential. 


\subsection{CONCLUSIONS}

The first run utilizing the Glycolic-Formic-Nitric Acid Flowsheet (referred to as the Glycolic-Formic Flowsheet throughout this report) with actual waste was demonstrated in Shielded Cells Run 13 (SC-13). The Glycolic-Formic Flowsheet utilizes 4 moles of glycolic acid per mole of formic acid mixture (the reducing acid) to replace the formic acid used in the DWPF Sludge Receipt \& Adjustment Tank (SRAT) processing. Nitric acid, an oxidizing acid, is still also used. Other than the change in acids, there are no differences in the flowsheets. The testing was completed with a Tank 51 Sludge Batch 5 (SB5) slurry sample that was available. Some conclusions include:

- No significant issues with processing were noted. SC-13 SRAT cycle processing of Tank 51 -SB5 sludge met DWPF qualification criteria (nitrite was destroyed, mercury was removed, and hydrogen generation was below DWPF limits) with 12 hours of reflux.

- SC-13 processing was comparable to the respective simulant work. The comparable simulant run (GF6 - 100\% Koopman acid stoichiometry and $1.45 \mathrm{~mol} / \mathrm{L}$ of acid added to a SB6 simulant) produced a peak hydrogen of $0.013 \mathrm{lb} / \mathrm{hr}$ DWPF-Scale, higher than observed in the SC-13 SRAT cycle.

The Glycolic-Formic Flowsheet has the following advantages over the current DWPF flowsheet:

- The hydrogen generation is greatly reduced as free formic acid concentration is much lower in the Glycolic-Formic Flowsheet. No catalytic hydrogen was detected throughout processing. The GC hydrogen detection limit is $>0.001$ volume $\%$.

- The generation volume of carbon dioxide and nitrous oxide was approximately one-third what is typical in a baseline flowsheet run. This will reduce emissions and has the potential to lower foaming in the SRAT.

- Each mole of glycolic acid has two moles of carbon. To produce a melter feed with a balanced REDOX (as measured by $\mathrm{Fe}^{2+} / \Sigma \mathrm{Fe}$ ), this allows the use of more nitric acid and less reducing acid.

- Since little formic acid is used, there is little acid consumed during processing. This keeps the slurry at approximately the same $\mathrm{pH}$ throughout processing and avoids the high $\mathrm{pH}$ melter feeds that can be very thick and tacky.

- The Glycolic-Formic Flowsheet is able to dissolve a large fraction of the insoluble metals in the sludge. This is a combination of the chelating ability of glycolic acid and the use of more nitric acid. This makes the resulting slurry more fluid and allows more concentration (i.e., higher total solids) of the SRAT product without exceeding DWPF rheological limits.

- With lower hydrogen generation levels, the flowsheet offers a much larger acid window for processing than the current flowsheet.

- The glassware, $\mathrm{pH}$ probe, agitator and thermocouple post-testing were very clean compared to baseline flowsheet runs. The Glycolic-Formic Flowsheet's ability to dissolve metals is likely leading to fewer deposits and less scale build-up during processing.

In addition to being the first demonstration of the Glycolic-Formic Flowsheet with radioactive sludge, a prime focus was the determination of solubility of iron and fissile isotopes during processing. The use of iron as a neutron poison relies on its insolubility to prevent a criticality if mixing is lost. No Slurry Mix Evaporator (SME) cycle was performed because the preparation of the $\mathrm{pH} \mathrm{3,} \mathrm{pH} 2$, and $\mathrm{pH} 1$ SRAT products consumed virtually the entire SRAT product. During SRAT processing, the iron was very insoluble, with a peak solubility of $2.2 \%$ at a $\mathrm{pH}$ of 1 . It should be noted that a $\mathrm{pH}$ of less than 4 is not expected during normal processing. The data also indicated that a fraction of the fissile components in the sludge slurry became soluble. 
SRNL-STI-2011-00622

Revision 0

- The soluble Pu-239 in solution had a concentration of $18.5 \mathrm{mg} / \mathrm{kg}\left(0.0427 \mathrm{~g}{ }^{239} \mathrm{Pu}\left(\mathrm{NO}_{3}\right)_{4} / \mathrm{L}, 0.58 \%\right.$ of the $7.3 \mathrm{~g} / \mathrm{L}$ limit (ANS Standard for nuclear criticality safety).

- The Fe/Pu-239 ratio in the slurry was 383:1 at $\mathrm{pH} 1$, greater than the 160:1 Fe:Pu-239 safe weight ratio.

- The $\mathrm{Mn} / \mathrm{Pu}-239$ ratio in the slurry was 90.3:1 at $\mathrm{pH}$ 1, greater than the 29:1 $\mathrm{Mn}: \mathrm{Pu}-239$ safe weight ratio. 


\subsection{RECOMMENDATIONS}

Although the run was a successful demonstration utilizing the Glycolic-Formic Acid Flowsheet for DWPF SRAT processing of actual waste, no SME cycle was completed. As a result, it is recommended that:

- SRNL complete a SRAT/SME cycle using actual waste to demonstrate the entire flowsheet. Utilize the SME product to produce glass and measure resulting glass Reduction/Oxidation Potential (REDOX) potential.

- Continue developing and testing of the Glycolic-Formic Flowsheet to eliminate formic acid. This testing should be completed before the testing of the full Chemical Process Cycle (CPC) with radioactive slurry so the flowsheet to be used is demonstrated, which would reduce the number of radioactive demonstrations required. The use of a single acid would simplify acid procurement and processing in DWPF by reducing the hazards associated with formic acid. 


\subsection{ACKNOWLEDGEMENTS}

This run was planned quickly in order to expedite the testing needed to answer a potential Achilles' heel for this flowsheet, namely the solubility of iron during processing. A number of people did extensive work in preparing for the testing and in analyzing the samples. This run generated four times the samples compared to a typical SRAT cycle so the work by the shielded cells technicians and AD are truly appreciated. Some of those deserving special acknowledgement include:

Rita Sullivan and Dee Wheeler were the shielded cells technicians that led these experiments. Their expertise and experience was invaluable in making these experiments successful. In addition, Carl Black and Linda Bush did an excellent job in supporting this experiment.

David Healy prepared most of the bottles that were used for samples during this run and his help is much appreciated.

Monica Jenkins, Jane Howard and Rita Sullivan prepared the samples in the cells and transferred them to AD. In addition, they completed digestions as needed for these samples, along with density and solids measurements. This work took them several weeks to complete after the run was finished.

Curtis Johnson (now retired), Mark Jones, Boyd Wiedenman, and Tom White, together with their technicians were responsible for analyzing the anion, ICP-AES and ICP-MS samples. Their help was much appreciated, especially their effort to get it completed in FY11. This was the first time that AD has analyzed samples for glycolate using the IC.

John Pareizs took the night shift for this run and was responsible for the majority of the processing, as the day shift spent their time fixing problems and did little actual processing. His oversight of this run is appreciated.

Curt Sexton assisted the shielded cells technicians by providing a tool to allow the installation of an Oring on the $\mathrm{pH}$ probe in cell. If I hadn't seen this, I wouldn't have believed it could be done. Curt's experience and "let's figure out how do this" attitude at the end of the day was much appreciated. 


\subsection{REFERENCES}

1 Wagnon, T.J., Defense Waste Processing Facility Alternate Reductant, Systems Engineering Study, Technical Report G-AES-S-00003, Revision 0, Savannah River Site: Aiken, SC 29808 (2011).

2 Fellinger, T. L.,.; Occhipinti, J. E., Follow-up Action for Senior Review Group (SRG) - Alternative Reductant Flowsheet Selection, Interoffice Memorandum SRR-WSE-2011-00184, Rev. 0, Savannah River Site: Aiken, SC 29808 (2011).

3 Fellinger, T. L., Nitric/Formic/Glycolic Flowsheet Tasks - Determination of Fe/Pu Solubility and Impact to Solvent Extraction, Technical Task Request HLW-DWPF-TTR-2011-0025, Rev. 1, Savannah River Site: Aiken, SC 29808 (2011).

4 Lambert, D. P.; Pareizs, J. M.; Task Technical and Quality Assurance Plan for Demonstration of the Glycolic-Formic Flowsheet in the Shielded Cells, Technical Report WSRC-RP-2011-01281, Rev. 0, Savannah River Site: Aiken, SC 29808 (2011).

5 Lambert, D. P.; Pareizs, J. M.; Click, D. R. Analytical Study Plan for Demonstration of the GlycolicFormic Flowsheet in the Shielded Cells, Technical Report WSRC-RP-2011-01282, Rev. 0, Savannah River Site: Aiken, SC 29808 (2011).

6 Pickenheim, B.R., Stone, M.E., Peeler, D.K.,' Selection and Preliminary Evaluation of Alternative Reductants for SRAT Processing, SRNL-STI-2009-00120, Savannah River National Laboratory, Aiken, SC, June 29808 (2009).

7 Pickenheim, B.R., Bibler, N.E., Lambert, D.P., Hay, M.S., Glycolic-Formic Acid Flowsheet Development, SRNL-STI-2010-00523, Rev 0, Savannah River National Laboratory, Aiken, SC, 29808 (2010).

8 Lambert, D.P., Pickenheim, B.R., Stone, M.E., Newell, J.D., Best, D.R., Glycolic - Formic Acid Flowsheet Final Report for Downselection Decision, Technical Report SRNL-STI-2010-00523, Rev 1, Savannah River Site: Aiken, SC 29808 (2011).

9 Pickenheim, B.R., M.E. Stone, J.D.M.E., Newell, Glycolic-Formic Acid Flowsheet Development, Glycolic Acid Physical Properties, Impurities, and Radiation Effects Assessment, SRNL-STI-20100052300314, Rev 01, Savannah River National Laboratory, Aiken, SC, November 29808 (2010).

10 Choi, A.S., Melter Off-Gas Flammability Assessment for DWPF Alternate Reductant Flowsheet Options, Technical Report SRNL-STI-2011-00321, Revision 0, Savannah River Site: Aiken, SC 29808 (2011).

11 Lambert, D.P., Koopman, D.C., Glycolic-Formic Acid Flowsheet Sludge Matrix Study, Technical Report SRNL-STI-2011-00275, Revision 0, Savannah River National Laboratory, Aiken, SC, 29808 (2011).

12 Analytical Development Procedures Manual; Manual L16; Savannah River National Laboratory: Aiken, SC 29808. 
13 Analytical Development Procedures Manual; Manual L16; Savannah River National Laboratory: Aiken, SC 29808.

14 Process Science and Engineering Section Procedure Manual; Manual L29; Savannah River National Lab: Aiken, SC 29808.

15 Stone, M. E. Lab-Scale CPC Equipment Set-up; Interoffice Memorandum SRNL-PSE-2006-00074; Rev, 2, Savannah River National Laboratory: Aiken, SC 29808. (2010).

16 SC13 Shielded Cells Demo of Glycolic-Formic Flowsheet; Notebook WSRC-NB-2011-00118; Savannah River National Laboratory: Aiken, SC, 29808 (2011.).

17 Lambert, D. P. Acid Calculation Spreadsheet for DWPF Simulations, Revision 1; Inter-Office Memorandum SRNL-PSE-2006-00173; Savannah River National Laboratory: Aiken, SC, 29808 (2006.).

18. Jantzen, C.M.; Zamecnik, J. R.; Koopman, D. C.; Herman, C. C.; Pickett, J. B. Electron Equivalents Model for Controlling Reduction-Oxidation ( REDOX) Equilibrium during High Level Waste (HLW) Vitrification, Technical Report WSRC-TR-2003-00126, Savannah River Site, Aiken, SC 29808 (2003).

19 Darby, R., Chemical Engineering Fluid Mechanics, 2nd edition. Marcel Dekker: 2001.

20 Murray, M. D., Nuclear Criticality Safety Evaluation: H-Canyon Waste Stream Poisoning with Fe and Mn (U), N-NCS-H-00152, Revision 0, February 2003.

21 "American National Standard for Nuclear Criticality Safety in Operations with Fissionable Material Outside Reactors”, ANSI-ANS-8.1-1998, September 1998. 


\section{APPENDIX A. MASS BALANCES}

Table A - 1. Acid Calculation

\begin{tabular}{|c|c|c|c|}
\hline $\begin{array}{l}\text { SRNL SRAT Acid, Trim Chemical, } \\
\text { Dewater and Redox Calc Revised: }\end{array}$ & \multicolumn{2}{|c|}{$3 / 12 / 2009$} & \\
\hline Run Description: & \multicolumn{3}{|c|}{ SC-13 110\% 80:20 glycolic:formic ratio } \\
\hline Sludge Feed Batch \# & \multicolumn{3}{|c|}{ SB5 Qual SRNL washed Tk51 } \\
\hline SRAT Vessel Volume, L & \multicolumn{2}{|c|}{4} & \\
\hline $\begin{array}{l}\text { REDOX Equation }\left(7 \text { for } \mathrm{Mn}^{+7} \text {, }\right. \\
\left.\text { otherwise assumes } \mathrm{Mn}^{+4}\right)\end{array}$ & \multicolumn{2}{|c|}{7} & Enter 7 for newest redox equation \\
\hline Acid Equation & \multicolumn{2}{|c|}{2} & $\begin{array}{l}\text { Enter } 1 \text { for Hsu, } 2 \text { for Koopman, } 3 \\
\text { for cation }\end{array}$ \\
\hline Will ARP be added? & \multicolumn{2}{|c|}{ No } & Yes \\
\hline Will MCU be added? & \multicolumn{2}{|c|}{ No } & No \\
\hline Will there be a SME cycle? & \multicolumn{2}{|c|}{ No } & \\
\hline $\begin{array}{l}\text { Fresh Sludge Slurry TIC (treated as } \\
\text { carbonate) }\end{array}$ & 1,011 & 1,401 & $\mathrm{mg} / \mathrm{kg}$ slurry \\
\hline $\begin{array}{l}\text { Fresh Supernate TIC (treated as } \\
\text { carbonate) }\end{array}$ & 1,202 & 1,228 & $\mathrm{mg} / \mathrm{L}$ supernate \\
\hline $\begin{array}{l}\text { Fresh Sludge Hydroxide (Base } \\
\text { Equivalents) } \mathrm{pH}=7\end{array}$ & 0.5548 & 0.5680 & Equiv Moles Base/L slurry \\
\hline $\begin{array}{l}\text { Fresh Sludge Manganese (\% of } \\
\text { Calcined Solids) }\end{array}$ & \multicolumn{2}{|l|}{4.844} & wt $\%$ calcined basis \\
\hline $\begin{array}{l}\text { Fresh Sludge Mercury (\% of Total } \\
\text { Solids in untrimmed sludge) }\end{array}$ & 1.9400 & NM & $\mathrm{wt} \%$ dry basis \\
\hline $\begin{array}{l}\text { Fresh Sludge Magnesium (\% of } \\
\text { Calcined Solids) }\end{array}$ & 0.727 & & wt $\%$ calcined basis \\
\hline $\begin{array}{l}\text { Fresh Sludge Sodium (\% of Calcined } \\
\text { Solids) }\end{array}$ & 19.200 & & wt $\%$ calcined basis \\
\hline $\begin{array}{l}\text { Fresh Sludge Potassium (\% of } \\
\text { Calcined Solids) }\end{array}$ & 0.079 & & wt $\%$ calcined basis \\
\hline $\begin{array}{l}\text { Fresh Sludge Calcium (\% of Calcined } \\
\text { Solids) }\end{array}$ & 1.530 & & wt $\%$ calcined basis \\
\hline $\begin{array}{l}\text { Fresh Sludge Nickel (\% of Calcined } \\
\text { Solids) }\end{array}$ & 2.710 & & wt $\%$ calcined basis \\
\hline Fresh Sludge Supernate manganese & & 0.053 & $\mathrm{mg} / \mathrm{L}$ supernate \\
\hline \multicolumn{3}{|c|}{$\begin{array}{ll}\text { Run \# } & \text { SC-13 }\end{array}$} & Units \\
\hline \multicolumn{3}{|c|}{\begin{tabular}{l|l} 
Table 2 -- SRAT Processing Assumptions, Run \# & SC-13
\end{tabular}} & \\
\hline \multicolumn{3}{|c|}{ Conversion of Nitrite to Nitrate in SRAT Cycle } & $\mathrm{gmol} \mathrm{NO}_{3}{ }^{-} / 100 \mathrm{gmol} \mathrm{NO}_{2}^{-}$ \\
\hline
\end{tabular}




\begin{tabular}{|c|c|c|}
\hline Run \# & SC-13 & Units \\
\hline Destruction of Nitrite in SRAT and SME cycle & 100.00 & $\%$ of starting nitrite destroyed \\
\hline Destruction of Formic acid charged in SRAT & 90.00 & $\%$ formate converted to $\mathrm{CO}_{2}$ etc. \\
\hline Destruction of Glycolic acid charged in SRAT & 0.00 & $\%$ glycolate converted to $\mathrm{CO}_{2}$ etc. \\
\hline Conversion of Glycolic acid to Oxalate & 3.00 & $\%$ glycolate converted to $\mathrm{C} 2 \mathrm{O} 4$ \\
\hline Destruction of Oxalate charged & 0.00 & $\%$ of total oxalate destroyed \\
\hline Percent Acid in Excess Stoichiometric Ratio & 110.00 & $\%$ \\
\hline SRAT Product Target Solids & 25.00 & $\%$ \\
\hline Nitric Acid Molarity & 10.200 & Molar \\
\hline Formic Acid Molarity & 23.537 & Molar \\
\hline Glycolic Acid Molarity & 11.826 & Molar \\
\hline DWPF Nitric Acid addition Rate & 2.0 & gallons per minute \\
\hline DWPF Formic Acid addition Rate & 4.080 & gallons per minute \\
\hline REDOX Target & 0.100 & $\mathrm{Fe}^{+2} / \sum \mathrm{Fe}$ \\
\hline Total nitrite & 0.185 & gmol \\
\hline Total Mn minus soluble Mn & 0.135 & gmol \\
\hline Total carbonate & 0.096 & gmol \\
\hline Total hydroxide & 0.555 & gmol \\
\hline Total mercury & 0.038 & gmol \\
\hline Total oxalate & 0.000 & gmol \\
\hline Total grams of calcined oxides & 152.760 & g \\
\hline Trim Chemicals Calculations & 0.0000 & \\
\hline $\begin{array}{l}\text { Fresh Sludge Calcine Factor }\left(1100^{\circ} \mathrm{C}\right) \text {, g oxide/g dry } \\
\text { solids (calculated) }\end{array}$ & 0.7836 & $\mathrm{~g} / \mathrm{g}$ \\
\hline ARP calcine factor & 0.0000 & $\mathrm{~g} / \mathrm{g}$ \\
\hline Total solids before trim addition & $\begin{array}{l}194.936 \\
8\end{array}$ & $\mathrm{~g}$ \\
\hline Total solids before trim less $\mathrm{HgO}, \mathrm{NaOxalate}$, coal) & 190.85 & $\mathrm{~g}$ \\
\hline Predicted total solids at target levels & $\begin{array}{l}194.936 \\
8\end{array}$ & $\mathrm{~g}$ \\
\hline Predicted total mass at target levels & $\begin{array}{l}1,270.00 \\
00\end{array}$ & g \\
\hline Target Ag metal content in trimmed sludge & $\begin{array}{l}0.00000 \\
0\end{array}$ & total $\mathrm{wt} \%$ dry basis \\
\hline $\mathrm{AgNO}_{3}$ to add $(\mathrm{CF}=0.682)$ & 0.00000 & $\mathrm{~g}$ \\
\hline Ag2O calcined solids & 0.00000 & $\mathrm{~g}$ \\
\hline Water added with Ag & 0.00000 & $\mathrm{~g}$ \\
\hline Target wt\% Hg dry basis & 1.940 & total $\mathrm{wt} \%$ dry basis \\
\hline Total HgO in fresh Sludge & 4.083 & g \\
\hline Total HgO in trimmed Sludge & 4.08341 & $\mathrm{~g}$ \\
\hline HgO to add & 0.00000 & $\mathrm{~g}$ \\
\hline HgO calcined solids & 0.00000 & $\mathrm{~g}$ \\
\hline Water added with $\mathrm{Hg}$ & 0.00000 & $\mathrm{~g}$ \\
\hline Calculated total wt\% Hg dry basis & 1.9400 & $\mathrm{wt} \%$ dry basis \\
\hline Target $P d$ metal content in trimmed sludge & 0.0000 & total wt $\%$ dry basis \\
\hline
\end{tabular}




\begin{tabular}{|c|c|c|}
\hline Run \# & SC-13 & Units \\
\hline Wt \% Pd in reagent solution & 15.2700 & $\mathrm{wt} \%$ in solution \\
\hline $\begin{array}{l}\mathrm{Pd}\left(\mathrm{NO}_{3}\right)_{2} * \mathrm{H}_{2} \mathrm{O} \text { solution to add }(\mathrm{CF}=1.150 \text { g metal } \\
\text { oxide/g metal })\end{array}$ & 0.00000 & g of solution \\
\hline Pd(NO3)2 to add & 0.00000 & $\mathrm{~g}$ \\
\hline PdO calcined solids & 0.00000 & $\mathrm{~g}$ \\
\hline Water added with Pd & 0.000 & $\mathrm{~g}$ \\
\hline Target $\mathrm{Rh}$ metal content in trimmed sludge & 0.0000 & total $\mathrm{wt} \%$ dry basis \\
\hline Wt\% $\mathrm{Rh}$ in reagent solution & 4.93 & $\mathrm{wt} \%$ in solution \\
\hline $\mathrm{Rh}\left(\mathrm{NO}_{3}\right)_{3} * 2 \mathrm{H}_{2} \mathrm{O}(\mathrm{CF}=1.311 \mathrm{~g}$ metal oxide/g metal $)$ & 0.0000 & g of solution \\
\hline Rh(NO3)3 to add & 0.00000 & $\mathrm{~g}$ \\
\hline Rh2O3 calcined solids & 0.00000 & $\mathrm{~g}$ \\
\hline Water added with $\mathbf{R h}$ & 0.000 & $\mathrm{~g}$ \\
\hline Target $R u$ metal content in trimmed sludge & 0.0000 & total $\mathrm{wt} \%$ dry basis \\
\hline $\mathrm{Wt} \% \mathrm{Ru}$ in $\mathrm{RuCl}_{3}$ reagent solids & 41.74 & $\mathrm{wt} \%$ in solids \\
\hline $\mathrm{RuCl}_{3}$ to add $(\mathrm{CF}=1.0)$ & 0.0000 & g solid \\
\hline Target $\mathrm{Cr}$ metal content in trimmed sludge & 0.0000 & total $\mathrm{wt} \%$ dry basis \\
\hline Cr2O3 to add & 0.0000 & g \\
\hline Target Ba metal content in trimmed sludge & 0.0000 & total $\mathrm{wt} \%$ dry basis \\
\hline BaO to add & 0.0000 & g \\
\hline Target $\mathrm{Cd}$ metal content in trimmed sludge & 0.0000 & total $\mathrm{wt} \%$ dry basis \\
\hline CdO to add & 0.0000 & g \\
\hline Target Gd metal content in trimmed sludge & 0.0000 & total $\mathrm{wt} \%$ dry basis \\
\hline wt\% Gd in reagent & 34.8392 & $\mathrm{wt} \%$ in solution \\
\hline Gd(NO3) $3 * 6 H_{20}$ to add & 0.0000 & g of reagent \\
\hline Gd(NO3)2 to add & 0.0000 & $\mathrm{~g}$ \\
\hline Gd2O3 calcined solids & 0.0000 & $\mathrm{~g}$ \\
\hline water added with Gd & 0.0000 & $\mathrm{~g}$ \\
\hline $\begin{array}{l}\text { Target } w t \% \text { Coal/carbon source in trimmed sludge, } \\
\text { dry basis }\end{array}$ & 0.00 & total $\mathrm{wt} \%$ dry basis \\
\hline Total Coal in fresh Sludge & 0.000 & $\mathrm{~g}$ \\
\hline Total Coal in trimmed Sludge & 0.000 & $\mathrm{~g}$ \\
\hline Mass of Coal to add $(C F=.08)$ & 0.00 & $\mathrm{~g}$ \\
\hline Calculated wt\% coal after trim additions & 0.00 & $\mathrm{wt} \%$ \\
\hline Total solids after trim addition & 194.94 & $\mathrm{~g}$ \\
\hline Match of actual to predicted total solids mass & $\begin{array}{l}100.00 \\
\%\end{array}$ & \\
\hline Total Calcined solids after trim & 152.76 & $\mathrm{~g}$ \\
\hline Water added to dilute and/or rinse trim chemicals & 130.0 & $\mathrm{~g}$ \\
\hline Mass of trimmed sludge & $1,270.00$ & $\mathrm{~g}$ \\
\hline Calculated wt\% total solids in trimmed sludge & 15.3 & $\mathrm{wt} \%$ \\
\hline Sample mass of trimmed sludge & 0.00 & $\mathrm{~g}$ \\
\hline Mass of trimmed feeds reacted & $1,270.00$ & $\mathrm{~g}$ \\
\hline Mass of equivalent sludge w/o ARP & $1,140.00$ & $\begin{array}{l}\text { g, used to calculate scaling factors, } \\
\text { etc. }\end{array}$ \\
\hline
\end{tabular}




\begin{tabular}{|c|c|c|}
\hline Run \# & SC-13 & Units \\
\hline Sample removal ratio at start of ARP boil & 1.000 & \\
\hline Sample removal ratio at start of SRAT & 1.000 & \\
\hline Calcined solids at start of SRAT & 152.8 & $\mathrm{~g}$ \\
\hline Hsu Total Stoichiometric Acid required & 1.0658 & gmol \\
\hline Koopman Minimum Stoichiometric Acid required & 1.2125 & gmol \\
\hline Koopman Minimum Stoichiometric Acid required & 1.2125 & gmol \\
\hline Cation Nominal Stoichiometric Acid required & 1.6432 & gmol \\
\hline Cation Minimum Stoichiometric Acid required & 1.4412 & gmol \\
\hline Percent Acid in Excess Stoichiometric Ratio & 110.000 & $\%$ \\
\hline Actual acid to add to SRAT & 1.3338 & gmol \\
\hline $\begin{array}{l}\text { Acid required in moles per liter of starting sludge } \\
\text { (less receipt samples) }\end{array}$ & 1.3337 & $\mathrm{gmol} / \mathrm{L}$ \\
\hline $\begin{array}{l}\text { REDOX CALCULATION (SME PRODUCT REDOX } \\
\text { PREDICTION) }\end{array}$ & & \\
\hline REDOX Target & 0.100 & $\mathrm{Fe}+2 / \mathrm{Fe}$ \\
\hline Predicted REDOX & 0.100 & \\
\hline Ratio of glycolic/formic acid to total acid & 0.6003 & $\begin{array}{l}\text { moles formic }+ \text { glycolic acid blend } \\
/ \text { mole total acid }\end{array}$ \\
\hline Delta between predicted REDOX and target REDOX & $\begin{array}{l}- \\
0.00003 \\
1\end{array}$ & \\
\hline Acid blend ratio & $\begin{array}{l}0.79996 \\
0383\end{array}$ & moles glycolic / mole blend \\
\hline $\begin{array}{l}\text { Activation of SME cycle corrections? }(1=\mathrm{SME} \\
\text { corrections performed): }\end{array}$ & 0 & \\
\hline Nitric acid density, $20^{\circ} \mathrm{C}$ & 1.30502 & $\mathrm{~g} / \mathrm{mL}$ \\
\hline Formic acid density, $20^{\circ} \mathrm{C}$ & 1.2043 & $\mathrm{~g} / \mathrm{mL}$ \\
\hline Glycolic/Formic blend density, $20^{\circ} \mathrm{C}$ & 1.2644 & $\mathrm{~g} / \mathrm{mL}$ \\
\hline Nitric acid, wt \% & 49.25 & wt $\%$ \\
\hline Formic acid, wt \% & 89.95 & wt \% \\
\hline Glycolic acid, wt \% & 71.00 & wt \% \\
\hline Glycolic acid in blend, wt\% & 68.66 & $\mathrm{wt} \%$ \\
\hline Formic acid in blend, wt\% & 10.39 & $\mathrm{wt} \%$ \\
\hline Formic acid amount & 0.160 & gmol \\
\hline Nitric acid amount & 0.533 & gmol \\
\hline Glycolic acid amount & 0.641 & gmol \\
\hline Total Manganese in fresh feed & 0.135 & gmol \\
\hline Manganese removed with SRAT product sample & 0.033 & gmol \\
\hline Projected Melter Feed Manganese, total moles & 0.101 & gmol \\
\hline Formate moles with fresh sludge & 0.000 & gmol \\
\hline
\end{tabular}




\begin{tabular}{|c|c|c|}
\hline Run \# & SC-13 & Units \\
\hline Formate moles added with formic acid & 0.160 & gmol \\
\hline $\begin{array}{l}\text { Formate moles destroyed in SRAT (\% of acid } \\
\text { charged) }\end{array}$ & 0.144 & gmol \\
\hline Formate moles removed with SRAT product sample & 0.004 & gmol \\
\hline Formate moles reacted in SME (\% of acid charged) & 0.000 & gmol \\
\hline Formate Moles after SME & 0.012 & gmol \\
\hline $\begin{array}{l}\text { Frit slurry formate (when SME cycle frit additions } \\
\text { are made with formic acid) }\end{array}$ & 0.000 & gmol \\
\hline Projected Melter Feed Formate, total moles & 0.012 & gmol \\
\hline Nitrate moles from fresh sludge, ARP, and MCU & 0.267 & gmol \\
\hline Nitrate moles from nitric acid & 0.533 & gmol \\
\hline $\begin{array}{l}\text { Nitrate from conversion of nitrite to nitrate in SRAT } \\
\text { and SME }\end{array}$ & 0.000 & gmol \\
\hline Nitrate from minor trim chemicals & 0.00000 & gmol \\
\hline Nitrate removed with SRAT product sample & 0.19787 & gmol \\
\hline Nitrate destroyed in the SME & 0.00000 & gmol \\
\hline $\begin{array}{l}\text { Projected Melter Feed Nitrate, total moles (Sum of } \\
\text { inputs - destroyed) }\end{array}$ & 0.602 & gmol \\
\hline Glycolate added with acid & 0.641 & gmol \\
\hline Glycolate moles destroyed in SRAT & 0.019 & gmol \\
\hline Glycolate moles removed with SRAT product sample & 0.154 & gmol \\
\hline Glycolate moles reacted in SME & 0.000 & gmol \\
\hline Projected Melter Feed Glycolate, total moles & 0.468 & gmol \\
\hline Oxalate in fresh feed & 0.000 & gmol \\
\hline Oxalate from trim & 0.000 & gmol \\
\hline Oxalate destroyed during reaction & 0.000 & gmol \\
\hline Oxalate created from glycolate & 0.019 & gmol \\
\hline Oxalate removed with SRAT product sample & 0.000 & gmol \\
\hline Projected Melter Feed Oxalate, total moles & 0.019 & gmol \\
\hline Carbon from Coal in fresh feed & 0.000 & gmol \\
\hline Carbon from trim coal & 0.000 & gmol \\
\hline Carbon removed in SRAT product Sample & 0.000 & gmol \\
\hline Projected Melter Feed Carbon from coal, total moles & 0.000 & gmol \\
\hline & $\begin{array}{l}- \\
335544 . \\
320\end{array}$ & \\
\hline Projected Melter Feed Nitrite, total moles & 0.0000 & gmol \\
\hline Assumed SME density & 1.400 & $\mathrm{~g} / \mathrm{ml}$ \\
\hline Projected final SME mass & $\mathbf{0 . 8 9 7}$ & $\mathrm{kg}$ \\
\hline Manganese concentration in final melter feed & 0.113 & gmol/kg melter feed slurry \\
\hline Formate concentration in final melter feed & 0.013 & gmol/kg melter feed slurry \\
\hline
\end{tabular}




\begin{tabular}{|c|c|c|}
\hline Run \# & SC-13 & Units \\
\hline Glycolate concentration in final melter feed & 0.521 & gmol/kg melter feed slurry \\
\hline Oxalate concentration in final melter feed & 0.021 & gmol/kg melter feed slurry \\
\hline Carbon from coal concentration in final melter feed & 0.000 & gmol/kg melter feed slurry \\
\hline Nitrate concentration in final melter feed & 0.671 & gmol/kg melter feed slurry \\
\hline Nitrite concentration in final melter feed & 0.000 & gmol/kg melter feed slurry \\
\hline Projected final SME volume & 0.641 & liters \\
\hline \multicolumn{3}{|l|}{ BENCH SCALE CALCULATIONS } \\
\hline \multicolumn{3}{|l|}{ Bench Scale Operational Setting } \\
\hline $\begin{array}{l}\text { Scaled formic/glycolic acid feed rate based on } \\
\text { nominal } 23.551 \mathrm{M}\end{array}$ & 0.6890 & $\mathrm{ml} / \mathrm{min}$ \\
\hline $\begin{array}{l}\text { Scaled nitric acid feed rate based on nominal } 10.395 \\
\text { M }\end{array}$ & 0.3440 & $\mathrm{ml} / \mathrm{min}$ \\
\hline Prototypical formic/glycolic acid feed time & 88.5 & $\min$ \\
\hline Prototypical nitric acid feed time & 151.9 & $\min$ \\
\hline Formic/glycolic acid volume required & 60.968 & $\mathrm{ml}$ \\
\hline Nitric acid volume required & 52.265 & $\mathrm{ml}$ \\
\hline Wt $\%$ active agent in antifoam solution & 10 & $\%$ \\
\hline Target concentration for overall SRAT cycle & 800 & $\mathrm{ppm}$ \\
\hline Total SRAT antifoam charge for $1: 10$ dilution & 9.12 & $\mathrm{~g}$ \\
\hline 100 ppm SRAT antifoam charge at 1:10 & 1.14 & $\mathrm{~g}$ \\
\hline \multicolumn{3}{|l|}{$\begin{array}{l}\text { Dewatering Calc for Target Wt. \% Total Solids in SRAT } \\
\text { Product }\end{array}$} \\
\hline $\begin{array}{l}\text { Final SRAT Product Total Solids (UNDER TOOLS } \\
\text { USE SOLVER) }\end{array}$ & 25.00 & $\%$ \\
\hline Water in Trimmed (and sampled) Sludge & $1,075.06$ & $\mathrm{~g}$ \\
\hline Water added with antifoam & 17.33 & $\mathrm{~g}$ \\
\hline Water added with formic/glycolic acid blend & 17.34 & $\mathrm{~g}$ \\
\hline Water added with nitric acid & 34.61 & $\mathrm{~g}$ \\
\hline Water added in acid flushing & 20.00 & $\mathrm{~g}$ \\
\hline Water made during base equiv neutralization & 9.99 & $\mathrm{~g}$ \\
\hline Water made in TIC destruction & 1.73 & $\mathrm{~g}$ \\
\hline Water made in SRAT nitrite destruction & 1.11 & $\mathrm{~g}$ \\
\hline Water made in Mercury Reduction & 0.34 & \\
\hline Revised water mass in slurry & $1,177.52$ & $\mathrm{~g}$ \\
\hline Solids in Trimmed (and sampled) Sludge & 194.94 & $\mathrm{~g}$ \\
\hline Mass 1:20 antifoam added & 0.91 & $\mathrm{~g}$ \\
\hline Mass of pure formic acid (HCOOH) added & 7.37 & $\mathrm{~g}$ \\
\hline Mass of pure nitric acid (HNO3) added & 33.59 & $\mathrm{~g}$ \\
\hline Mass of pure glycolic acid $\left(\mathrm{HOCH}_{2} \mathrm{COOH}\right)$ & 48.71 & $\mathrm{~g}$ \\
\hline Solids lost during base equiv neutralization & 9.99 & $\mathrm{~g}$ \\
\hline Solids lost in TIC destruction & 5.95 & $\mathrm{~g}$ \\
\hline Solids lost in SRAT nitrite destruction & 4.81 & $\mathrm{~g}$ \\
\hline
\end{tabular}




\begin{tabular}{|c|c|c|}
\hline Run \# & SC-13 & Units \\
\hline Solids lost in SRAT nitrite destruction & 8.50 & $\mathrm{~g}$ \\
\hline $\begin{array}{l}\text { Solids lost in SRAT formate destruction (formic } \\
\text { acid) }\end{array}$ & 6.63 & $\mathrm{~g}$ \\
\hline $\begin{array}{l}\text { Solids lost in SRAT glycolate destruction (glycolic } \\
\text { acid) }\end{array}$ & 1.46 & $\mathrm{~g}$ \\
\hline Solids lost in Mercury Stripping & 4.08 & \\
\hline Revised solids mass in slurry & 252.59 & $\mathrm{~g}$ \\
\hline $\begin{array}{l}\text { Target final water mass in slurry to hit total solids } \\
\text { target }\end{array}$ & 757.77 & $\mathrm{~g}$ \\
\hline Total water to remove (ARP and in SRAT) & 419.75 & g \\
\hline Total water to remove in ARP step & 0.00 & $\begin{array}{l}\text { g to return to } \mathrm{wt} \% \mathrm{TS} \text { of starting } \\
\text { sludge }\end{array}$ \\
\hline $\begin{array}{l}\text { Calculated total water to remove to return to starting } \\
\text { volume }\end{array}$ & 293.39 & $\mathrm{~g}$ \\
\hline net (used in Macro iteration) & -126.36 & $\mathrm{~g}$ \\
\hline Time to dewater ARP & 0.00 & minutes \\
\hline Mass of carbonate lost as $\mathrm{CO}_{2}$ & 4.22 & $\mathrm{~g}$ \\
\hline Mass of nitrite lost as NO & 3.70 & $\mathrm{~g}$ \\
\hline Formate converted to $\mathrm{CO}_{2}$ & 6.63 & $\mathrm{~g}$ \\
\hline Formate converted to $\mathrm{CO} 2$ in SRAT & 6.63 & $\mathrm{~g}$ \\
\hline Glycolate converted to CO2 in SRAT & 1.69 & \\
\hline $\begin{array}{l}\text { Final sludge mass in SRAT after acid addition and } \\
\text { dewater (neglecting samples) }\end{array}$ & 1010.36 & $\mathrm{~g}$ \\
\hline $\begin{array}{l}\text { Mass of SRAT cycle samples (excluding SRAT } \\
\text { Receipt) }\end{array}$ & 250.00 & $\mathrm{~g}$ \\
\hline Mass of treated sludge going into SME cycle & 760.36 & $\mathrm{~g}$ \\
\hline SME sample ratio & 0.7526 & \\
\hline Calcined Solids going to SME & 114.96 & $\mathrm{~g}$ \\
\hline \multicolumn{3}{|l|}{ DWPF SCALE TO BENCH SCALE } \\
\hline \multicolumn{3}{|l|}{ DWPF Scale SRAT cycle } \\
\hline density estimate $=$ & 1.126 & \\
\hline Volume based scale factor 6000 gal starting SRAT & 22426.1 & \\
\hline Minimum SRAT conflux time & 720.0 & $\min$ \\
\hline \multicolumn{3}{|l|}{ Bench Scale SRAT cycle } \\
\hline $99.5 \%$ of scaled air purge & 289.0 & $\mathrm{sccm}$ \\
\hline Helium purge rate at $0.5 \mathrm{vol} \%$ & 1.4 & $\mathrm{sccm}$ \\
\hline Scaled boil-up rate & 1.69 & $\mathrm{~g} / \mathrm{min}$ \\
\hline $\begin{array}{l}\text { Required dewatering time at above rate (ARP and } \\
\text { after acid) }\end{array}$ & 249.0 & $\min$ \\
\hline \multicolumn{3}{|l|}{ DWPF Scale SME cycle } \\
\hline Bench Scale SME cycle & & \\
\hline
\end{tabular}




\begin{tabular}{|c|c|c|}
\hline Run \# & $\mathrm{SC}-13$ & Units \\
\hline $\begin{array}{l}\text { SME scale factor (ADJUSTED FOR SRAT } \\
\text { SAMPLES) }\end{array}$ & 29799.6 & \\
\hline 99.5\% scaled SME air purge & 70.0 & $\mathrm{sccm}$ \\
\hline Helium purge rate at $0.5 \mathrm{vol} \%$ & 0.35 & $\mathrm{sccm}$ \\
\hline Solids remaining at start of SME & 190.1 & $\mathrm{~g}$ \\
\hline SRAT product Calcine Factor (calculated) & 0.605 & g oxide/g dry SRAT Product \\
\hline Sludge calcined solids - based on SRAT product & 114.96 & $\mathrm{~g}$ \\
\hline Sludge oxide contribution in SME & 35.00 & $\%$ \\
\hline Frit oxide contribution & 65.00 & $\%$ \\
\hline Frit slurry wt \% solids & 50.00 & $\mathrm{wt} \%$ \\
\hline Frit slurry formic acid ratio & 0.00 & g $90 \mathrm{wt} \% \mathrm{FA} / 100 \mathrm{~g}$ Frit \\
\hline Added water simulating decontamination of canisters & 0.0 & $\mathrm{~g}$ \\
\hline SME cycle antifoam addition at $1: 10$ & 0.76 & $\mathrm{~g}$ \\
\hline Frit solids (total) & 213.5 & $\mathrm{~g}$ \\
\hline $\begin{array}{l}90 \text { wt \% formic acid (corrections necessary for other } \\
\text { concentrations) }\end{array}$ & 0.00 & $\mathrm{~g}$ \\
\hline Water in frit slurry & 213.5 & $\mathrm{~g}$ \\
\hline Scaled transfer water & 0.00 & $\mathrm{~g}$ \\
\hline Total frit slurry water & 213.5 & $\mathrm{~g}$ \\
\hline Total mass of frit slurry & 427.0 & $\mathrm{~g}$ \\
\hline Number of equal SME frit slurry additions & 2 & \\
\hline Each SME frit addition & 106.8 & $\mathrm{~g}$ \\
\hline Each SME 90-wt\% formic acid addition & 0.00 & $\mathrm{~g}$ \\
\hline Each SME water addition & 106.8 & $\mathrm{~g}$ \\
\hline Scaled SME boil-up rate & 1.27 & $\mathrm{~g} / \mathrm{min}$ \\
\hline Approximate time to remove water: & 84.2 & $\min$ \\
\hline Final solids content in SME & 403.7 & $\mathrm{~g}$ \\
\hline Target SME solids total wt\% & 45.0 & $\%$ \\
\hline Mass of water to boil off for final SME concentration & 78.3 & $\mathrm{~g}$ \\
\hline Scaled boil-up rate & 1.27 & $\mathrm{~g} / \mathrm{min}$ \\
\hline $\begin{array}{l}\text { Approximate time to reach solids target } \\
\text { concentration. }\end{array}$ & 61.8 & $\min$ \\
\hline
\end{tabular}

Table A - 2. Mass Balance

\begin{tabular}{|l|l|l|l|l|}
\hline & \multicolumn{4}{|l|}{ Planned VERSUS Actual Additions } \\
\hline SRAT Mass Balance SC-13 & Planned, g & Actual, g & Delta, $\mathbf{g}$ & \% Delta \\
\hline Sludge Simulant (grams) & $1,140.00$ & $1,127.36$ & -12.64 & $-1.11 \%$ \\
\hline Water to dilute/rinse trim chemicals (grams) & 130.00 & 130.00 & 0.00 & $0.00 \%$ \\
\hline
\end{tabular}




\begin{tabular}{|l|l|l|l|l|}
\hline Total Slurry (grams) & $1,270.00$ & $1,257.36$ & -12.64 & $-1.00 \%$ \\
\hline Slurry Mass after sample (grams) & $1,270.00$ & $1,257.36$ & -12.64 & $-1.00 \%$ \\
\hline SRAT Antifoam (and water) (grams) & 18.24 & 18.24 & 0.00 & $0.00 \%$ \\
\hline Nitric Acid solution (grams) & 68.21 & 68.21 & 0.00 & $0.00 \%$ \\
\hline Glycolic/Formic Acid solution (grams) & 77.08 & 77.08 & 0.00 & $0.00 \%$ \\
\hline $\begin{array}{l}\text { Water added to flush Nitric and Formic Acid } \\
\text { Lines }\end{array}$ & 20.00 & 20.00 & 0.00 & $0.00 \%$ \\
\hline Total Dewater (grams) & 419.75 & 415.65 & 25.90 & $6.17 \%$ \\
\hline MCU Simulant & 0.00 & 0.00 & 0.00 & $\mathrm{NA}$ \\
\hline MCU Dewater & & 0.00 & 0.00 & $\mathrm{NA}$ \\
\hline MWWT Dewater mass (grams) & & 30.00 & & \\
\hline SRAT FAVC Dewater mass (grams) & & 0.00 & & \\
\hline SRAT Sample (grams) & 250.00 & 251.05 & 1.05 & $0.4 \%$ \\
\hline SRAT Product Mass after sampling (grams) & 760.36 & 759.31 & -1.05 & $-0.14 \%$ \\
\hline
\end{tabular}

Table A - 3. Formate and Nitrate Balance

\begin{tabular}{|l|l|l|l|l|}
\hline Anion Conversion Balance (SRAT Cycle) & \multicolumn{1}{l}{ Planned, $\mathbf{l}$ Actual, g } & \multicolumn{1}{l|}{ Delta } \\
\hline SRAT Product Analysis: & & & & \\
\hline SRAT Product Total Solids, wt \% & 25.00 & 24.30 & -0.7 & $-2.80 \%$ \\
\hline SRAT Calcined Solids, wt \% & 15.12 & 14.81 & -0.3 & $-2.05 \%$ \\
\hline SRAT Mn, wt. \% calcined element & 4.84 & 4.485 & -0.4 & $-7.41 \%$ \\
\hline SRAT Formate, mg/kg & 758 & 759 & 0.5 & $0.07 \%$ \\
\hline SRAT Glycolate, mg/kg & 49,476 & 42,561 & $-6,915$ & $-13.98 \%$ \\
\hline SRAT Oxalate, mg/kg & 2,411 & 434 & $-1,977$ & $-82.00 \%$ \\
\hline SRAT Nitrite, mg/kg & 0 & 426 & 426.0 & NA \\
\hline SRAT Nitrate, mg/kg & 50,136 & 52,893 & $2,757.3$ & $5.50 \%$ \\
\hline $\begin{array}{l}\text { SRAT Formate Added as acid (best basis, } \\
\text { grams) }\end{array}$ & 7.834 & 7.834 & 0 & $0.00 \%$ \\
\hline $\begin{array}{l}\text { SRAT Glycolate Added as acid (best basis, } \\
\text { grams) }\end{array}$ & 52.222 & 52.222 & 0 & $0.00 \%$ \\
\hline Nitrate Added as acid (best basis, grams) & 33.054 & 33.054 & 0 & $0.00 \%$ \\
\hline Nitrite in Feed (grams) & 8.50 & 8.41 & 0 & $-1.11 \%$ \\
\hline Nitrate in Feed \& trim chemicals (grams) & 16.53 & 16.35 & 0 & $-1.11 \%$ \\
\hline Nitrite in SRAT product (grams) & 0.00 & 0.43 & 0 & NA \\
\hline Nitrate in SRAT product (grams) & 50.655 & 53.44 & 3 & $5.50 \%$ \\
\hline Formate in SRAT product (grams) & 0.78 & 0.77 & 0 & $-2.11 \%$ \\
\hline Glycolate in SRAT product (grams) & 50.66 & 43.00 & -8 & $-15.11 \%$ \\
\hline SRAT Formate Destruction (grams) & 7.050 & 7.067 & 0.0 & $0.23 \%$ \\
\hline SRAT Formate Destruction (\%) & $\mathbf{9 0 . 0}$ & $\mathbf{9 0 . 2}$ & 0.2 & $0.23 \%$ \\
\hline SRAT Glycolate Destruction (grams) & 1.6 & 9.2 & 7.7 & $488.51 \%$ \\
\hline SRAT Glycolate Destruction (\%) & $\mathbf{3 . 0}$ & $\mathbf{1 7 . 7}$ & 14.7 & $488.51 \%$ \\
\hline SRAT Nitrite Destruction (grams) & 8.5 & 8.0 & -0.5 & $-6.17 \%$ \\
\hline SRAT Nitrite Destruction (\%) & $\mathbf{1 0 0 . 0}$ & $\mathbf{9 4 . 9}$ & -5.1 & $-5.12 \%$ \\
\hline
\end{tabular}


SRNL-STI-2011-00622

Revision 0

\begin{tabular}{|l|l|l|l|l|}
\hline Anion Conversion Balance (SRAT Cycle) & \multicolumn{1}{l}{ Planned, $\mathrm{l}$ Actual, g } & \multicolumn{1}{l}{ Delta } & \multicolumn{1}{l}{ Delta } \\
\hline Nitrite to Nitrate Conversion (grams) & 1.07 & 4.04 & 3.0 & $277.28 \%$ \\
\hline Nitrate from nitrite in SRAT product, mol & 0.017 & 0.065 & 0.05 & $277.28 \%$ \\
\hline Moles of nitrite reacted & 0.185 & 0.185 & 0.000 & $0.00 \%$ \\
\hline \% nitrite conversion to nitrate & $\mathbf{0 . 0}$ & $\mathbf{3 5 . 2}$ & 35.2 & $\mathrm{NA}$ \\
\hline $\begin{array}{l}\text { Predicted SME product mass from forwarded } \\
\text { SRAT mass }\end{array}$ & 896.9 & 874.1 & & \\
\hline $\begin{array}{l}\text { Predicted SME Product Formate, gmol/kg SME } \\
\text { slurry }\end{array}$ & 0.013 & 0.015 & & \\
\hline $\begin{array}{l}\text { Predicted SME Product Oxalate, gmol/kg SME } \\
\text { slurry }\end{array}$ & 0.021 & 0.022 & & \\
\hline $\begin{array}{l}\text { Predicted SME Product Glycolate, gmol/kg } \\
\text { SME slurry }\end{array}$ & 0.521 & 0.493 & & \\
\hline $\begin{array}{l}\text { Predicted SME Product Coal, gmol/kg SME } \\
\text { slurry }\end{array}$ & 0.000 & 0.000 & & \\
\hline $\begin{array}{l}\text { Predicted SME Product Nitrate, gmol/kg SME } \\
\text { slurry }\end{array}$ & 0.671 & 0.686 & & \\
\hline $\begin{array}{l}\text { Predicted SME Product Nitrite, gmol/kg SME } \\
\text { slurry }\end{array}$ & 0.000 & 0.008 & & \\
\hline $\begin{array}{l}\text { Predicted SME Product Mn, gmol/kg SME } \\
\text { slurry }\end{array}$ & 0.113 & 0.105 & & \\
\hline Predicted Fe+2/Fe total in glass (no SME cycle) & $\mathbf{0 . 1 0 0}$ & $\mathbf{0 . 0 5 2}$ & & \\
\hline
\end{tabular}


SRNL-STI-2011-00622

Revision 0

\section{APPENDIX B. OFFGAS COMPOSITION DATA}

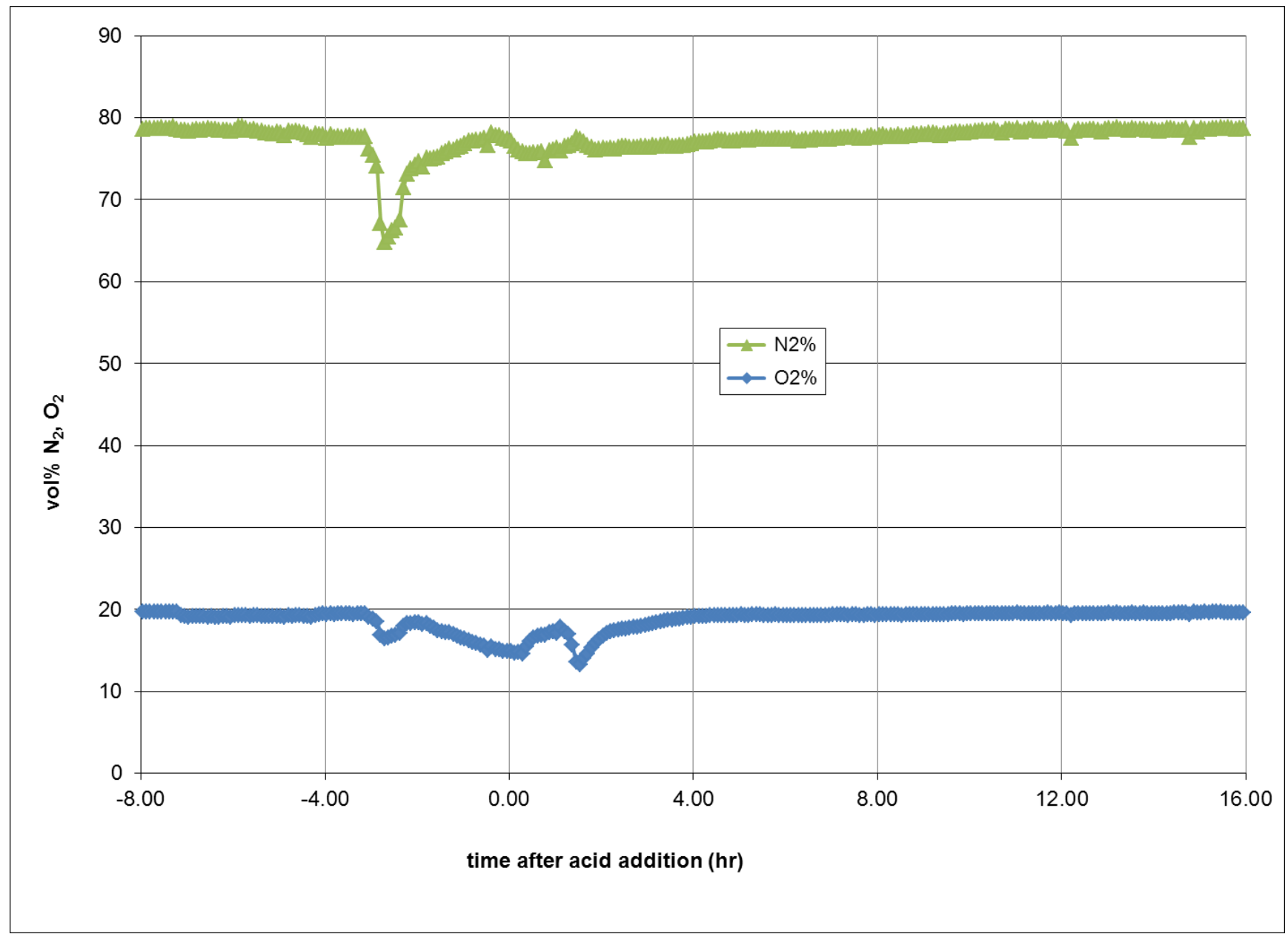

Figure B - 1. SC-13 SRAT Cycle $\mathrm{O}_{2}, \mathrm{~N}_{2}$ Offgas Data 
SRNL-STI-2011-00622

Revision 0

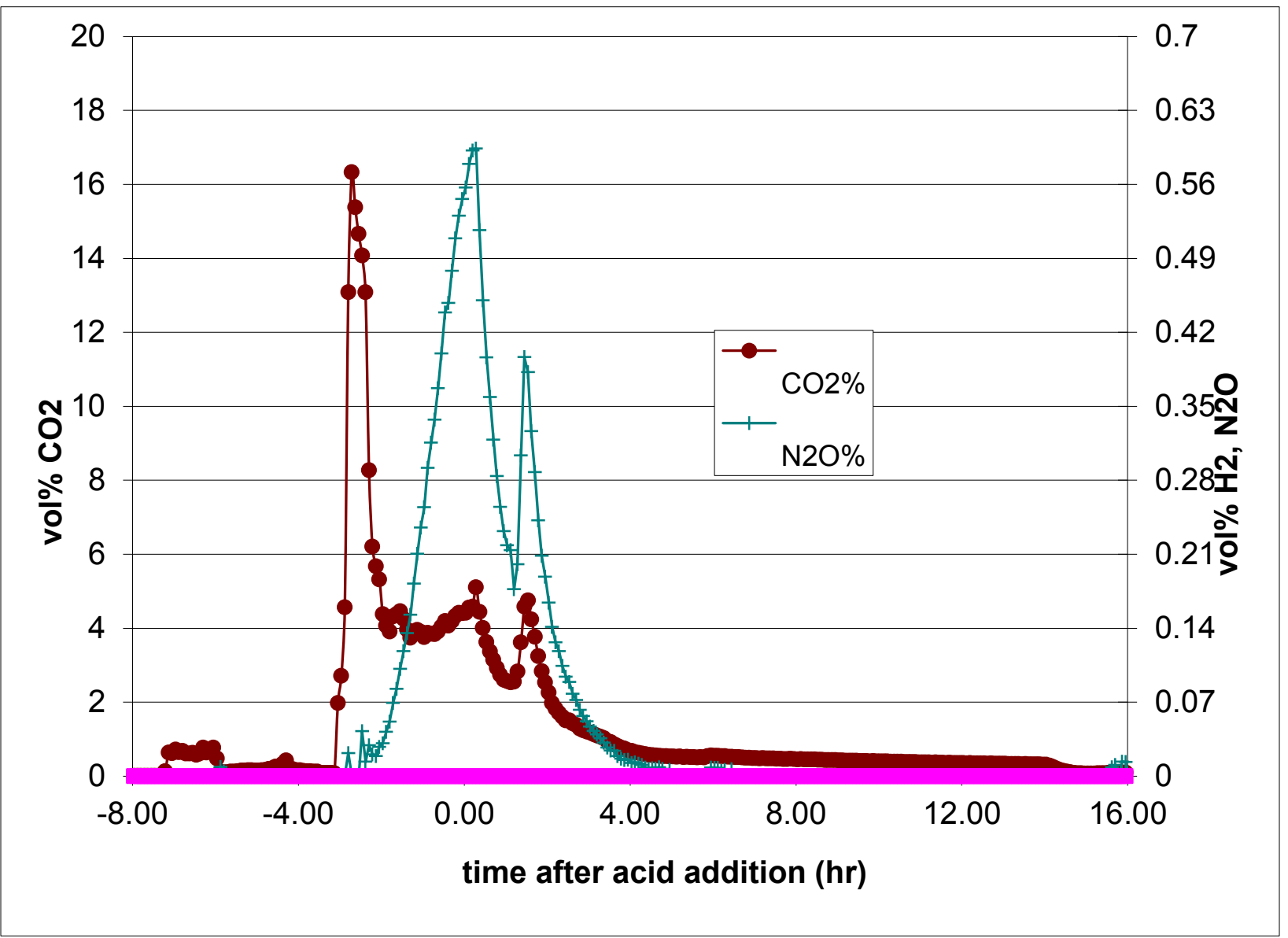


SRNL-STI-2011-00622

Revision 0

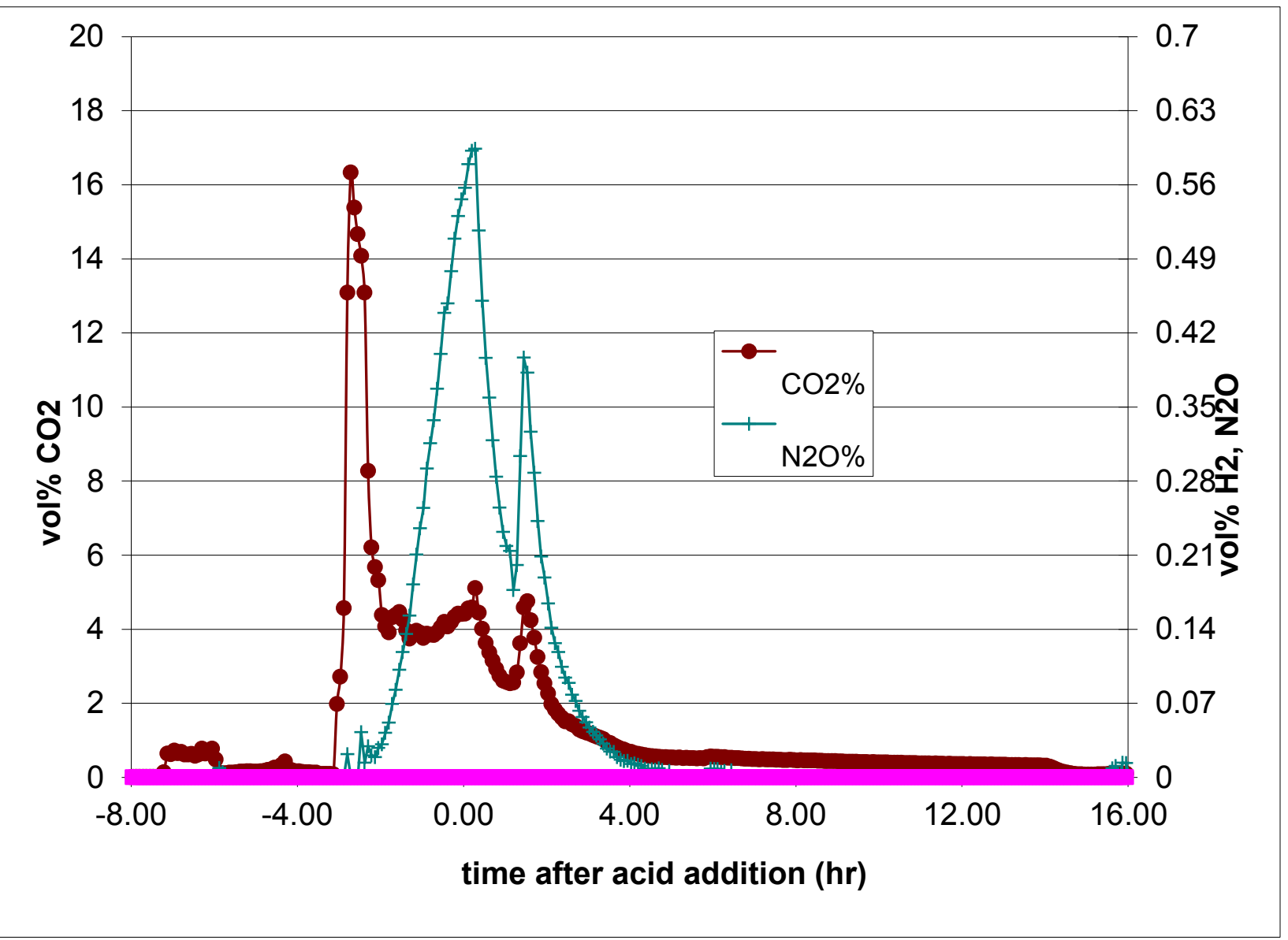


SRNL-STI-2011-00622

Revision 0

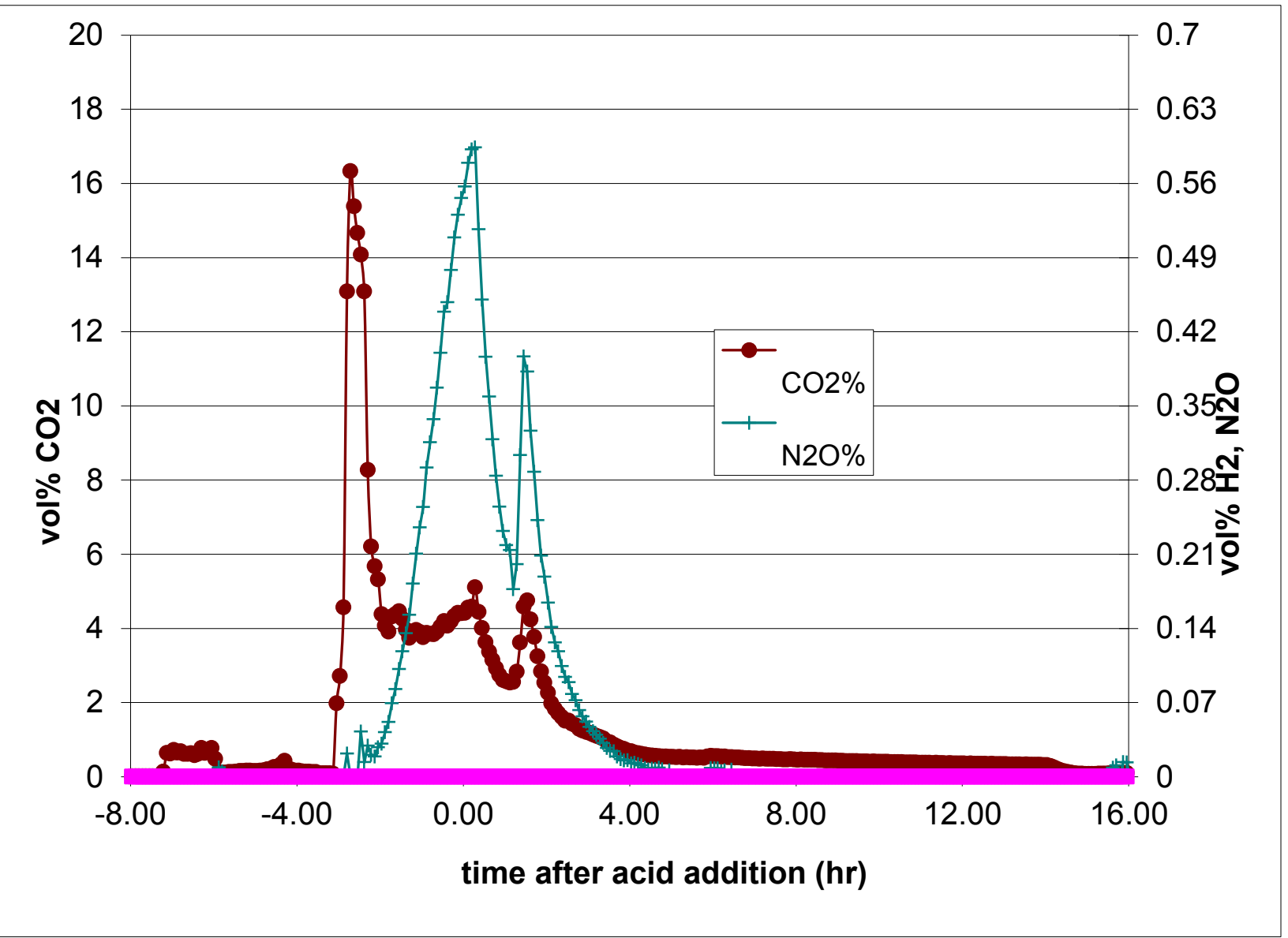

Figure B - 2. SC-13 SRAT Cycle $\mathrm{N}_{2} \mathrm{O}, \mathrm{CO}_{2}, \mathrm{H}_{2}$ Offgas Data 


\section{APPENDIX C. RHEOLOGICAL RESULTS CHARTS AND FLOW CURVES}


SRNL-STI-2011-00622

Revision 0

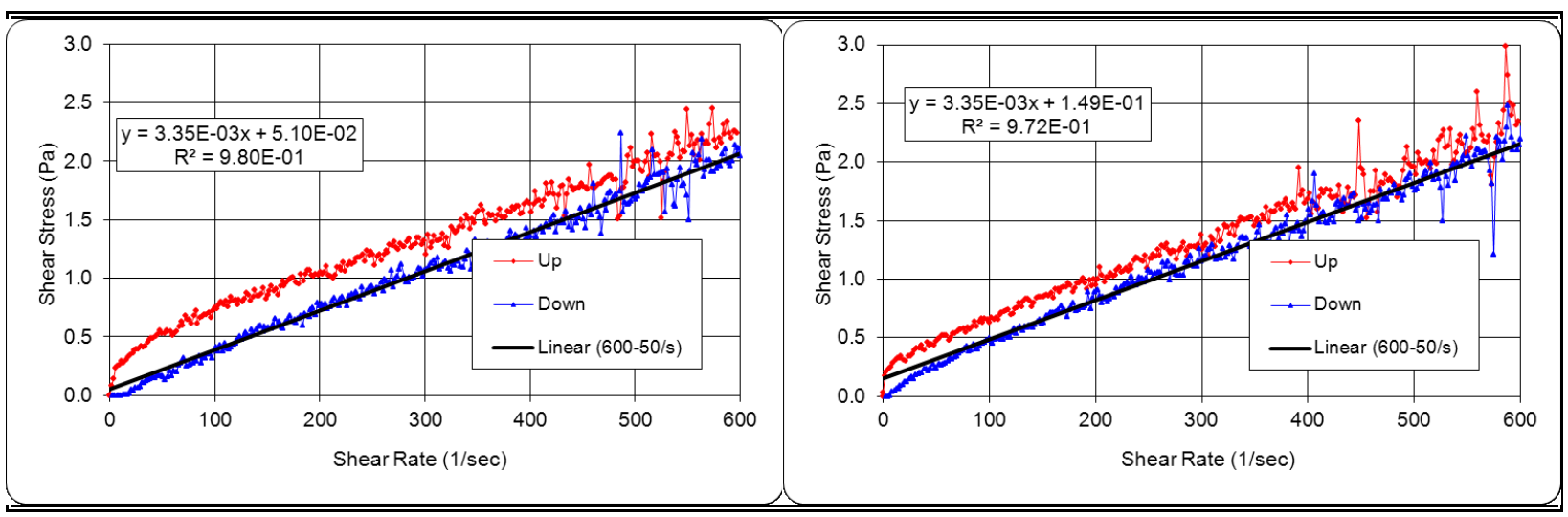

Figure C - 1 SRAT Product, Flow Curve

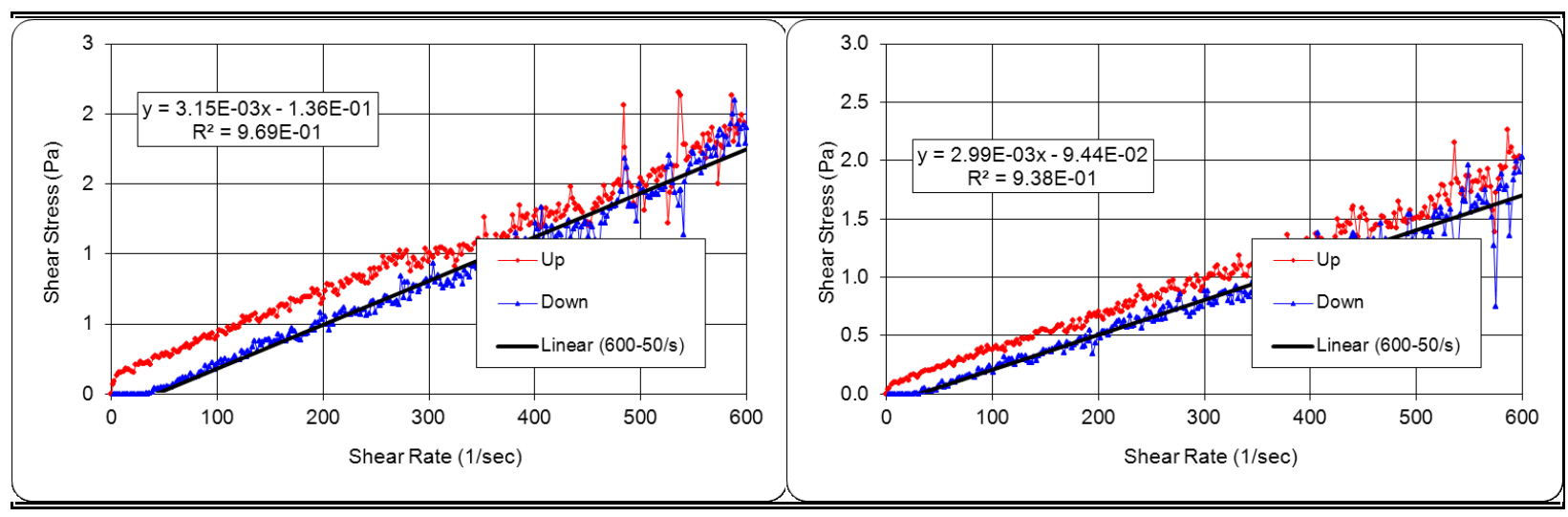

Figure C - 2 SRAT Product pH 2, Flow Curve 


\section{APPENDIX D. ICP-AES and ICP-MS Data Compilation}

Table D - 4. SRAT Receipt ICP-AES

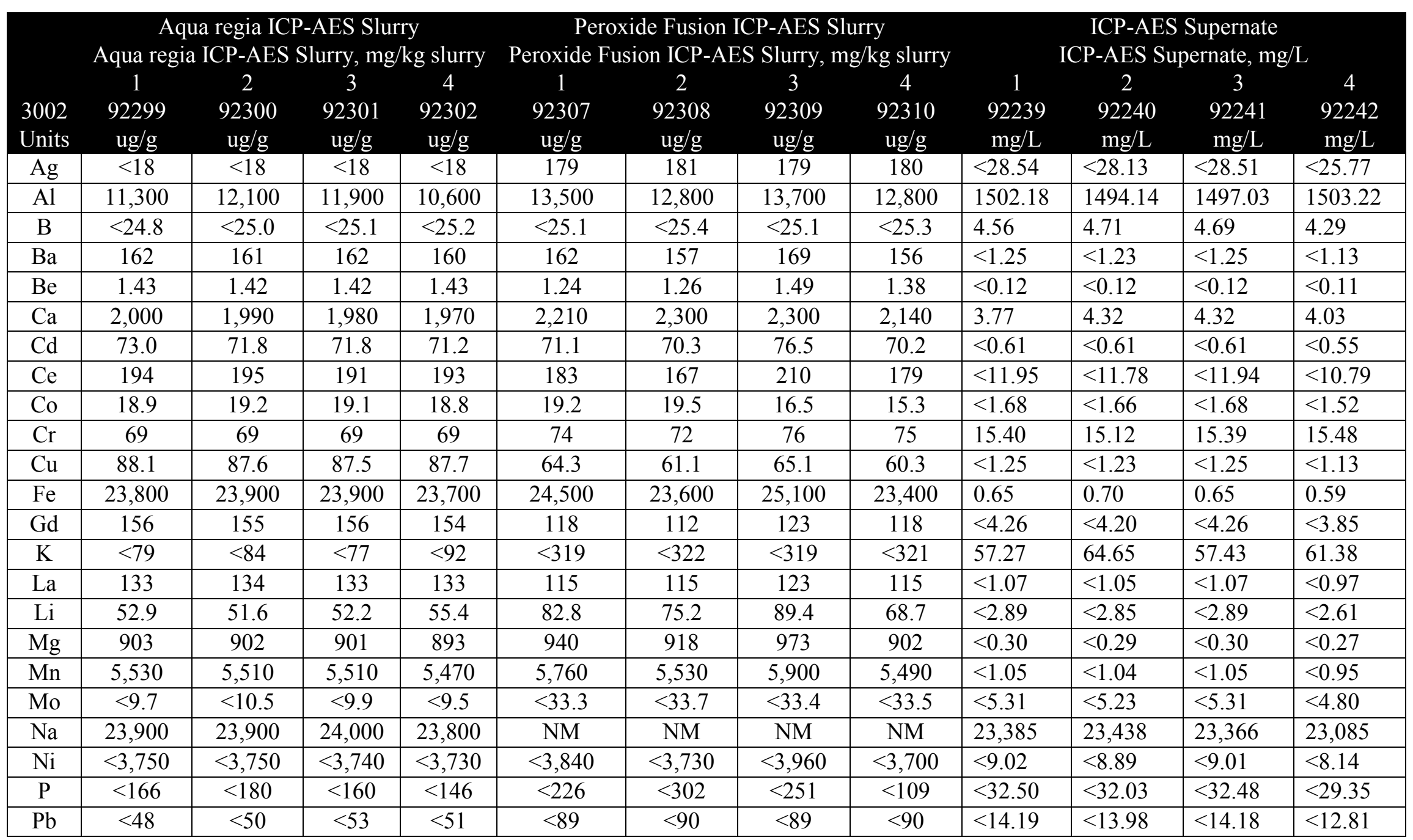


SRNL-STI-2011-00622

Revision 0

\begin{tabular}{|c|c|c|c|c|c|c|c|c|c|c|c|c|}
\hline & \multicolumn{4}{|c|}{ Aqua regia ICP-AES Slurry } & \multicolumn{4}{|c|}{ Peroxide Fusion ICP-AES Slurry } & \multicolumn{4}{|c|}{ ICP-AES Supernate } \\
\hline & Aqua res & CP-AE & urry, m & g slurry & Peroxide & on ICP-A & Slurry, & kg slurry & & CP-AES & ernate, $n$ & \\
\hline & 1 & 2 & 3 & 4 & 1 & 2 & 3 & 4 & 1 & 2 & 3 & 4 \\
\hline 3002 & 92299 & 92300 & 92301 & 92302 & 92307 & 92308 & 92309 & 92310 & 92239 & 92240 & 92241 & 92242 \\
\hline Units & $\mathrm{ug} / \mathrm{g}$ & $\mathrm{ug} / \mathrm{g}$ & $\mathrm{ug} / \mathrm{g}$ & $\mathrm{ug} / \mathrm{g}$ & $\mathrm{ug} / \mathrm{g}$ & $\mathrm{ug} / \mathrm{g}$ & $\mathrm{ug} / \mathrm{g}$ & $\mathrm{ug} / \mathrm{g}$ & $\mathrm{mg} / \mathrm{L}$ & $\mathrm{mg} / \mathrm{L}$ & $\mathrm{mg} / \mathrm{L}$ & $\mathrm{mg} / \mathrm{L}$ \\
\hline $\mathrm{S}$ & $<281$ & $<270$ & $<183$ & $<256$ & $<931$ & $<1,650$ & $<1,290$ & $<938$ & 208.09 & 146.48 & 196.04 & 220.11 \\
\hline $\mathrm{Sb}$ & 157 & 158 & 159 & 159 & 132 & 134 & 133 & 145 & $<21.20$ & $<20.90$ & $<21.19$ & $<19.15$ \\
\hline Sn & NM & NM & NM & NM & 1460 & 1440 & 1480 & 1320 & 12.37 & 10.45 & 10.18 & 10.93 \\
\hline $\mathrm{Sn}$ & $<62$ & $<62$ & $<63$ & $<63$ & $<70$ & $<71$ & $<70$ & $<70$ & $<11.12$ & $<10.96$ & $<11.11$ & $<10.04$ \\
\hline $\mathrm{Sr}$ & 81.3 & 81.1 & 81.5 & 80.4 & 79.5 & 77.3 & 83.7 & 77.4 & $<0.10$ & $<0.10$ & $<0.10$ & $<0.09$ \\
\hline Th & 271 & 270 & 272 & 268 & 218 & 207 & 224 & 205 & $<5.31$ & $<5.23$ & $<5.31$ & $<4.80$ \\
\hline $\mathrm{Ti}$ & 27.2 & 27.3 & 27.2 & 28.3 & 34.9 & 32.9 & 34.1 & 32.0 & $<0.75$ & $<0.74$ & $<0.75$ & $<0.68$ \\
\hline $\mathrm{U}$ & 8,010 & 7,970 & 7,960 & 7,910 & 7,970 & 7,700 & 8,250 & 7,530 & $<64.80$ & $<63.87$ & $<64.75$ & $<58.52$ \\
\hline $\mathrm{V}$ & $<5.78$ & $<5.81$ & $<5.85$ & $<5.86$ & $<5.83$ & $<5.90$ & $<5.85$ & $<5.88$ & $<0.93$ & $<0.92$ & $<0.93$ & $<0.84$ \\
\hline $\mathrm{Zn}$ & 77.5 & 77.5 & 77.9 & 76.9 & 82.4 & 79.0 & 87.4 & 80.8 & $<1.82$ & $<1.80$ & $<1.82$ & $<1.65$ \\
\hline
\end{tabular}

Table D - 5. SRAT Product ICP-AES

\begin{tabular}{|c|c|c|c|c|c|c|c|c|c|c|c|c|}
\hline \multirow{4}{*}{$\begin{array}{l}3002 \\
\text { Units }\end{array}$} & \multicolumn{4}{|c|}{ Aqua regia ICP-AES Slurry, mg/kg slurry } & \multicolumn{4}{|c|}{ Peroxide Fusion ICP-AES Slurry, mg/kg slurry } & \multicolumn{4}{|c|}{ ICP-AES Supernate, $\mathrm{mg} / \mathrm{L}$} \\
\hline & 1 & 2 & 3 & 4 & 1 & 2 & 3 & 4 & 1 & 2 & 3 & 4 \\
\hline & 92314 & 92315 & 92316 & 92317 & 92322 & 92323 & 92324 & 92325 & 92441 & 92442 & 92443 & 92444 \\
\hline & $\mathrm{ug} / \mathrm{g}$ & $\mathrm{ug} / \mathrm{g}$ & $\mathrm{ug} / \mathrm{g}$ & $\mathrm{ug} / \mathrm{g}$ & $\mathrm{ug} / \mathrm{g}$ & $\mathrm{ug} / \mathrm{g}$ & $\mathrm{ug} / \mathrm{g}$ & $\mathrm{ug} / \mathrm{g}$ & $\mathrm{mg} / \mathrm{L}$ & $\mathrm{mg} / \mathrm{L}$ & $\mathrm{mg} / \mathrm{L}$ & $\mathrm{mg} / \mathrm{L}$ \\
\hline $\mathrm{Ag}$ & $<28$ & $<28$ & $<28$ & $<28$ & 287 & 287 & 287 & 279 & $<28.54$ & $<28.13$ & $<28.51$ & $<25.77$ \\
\hline $\mathrm{Al}$ & 13,300 & 14,300 & 13,200 & 14,100 & 15,400 & 15,400 & 15,600 & 15,200 & 590.57 & 628.91 & 603.96 & 520.76 \\
\hline $\mathrm{B}$ & $<39.3$ & $<39.1$ & $<39.2$ & $<39.8$ & $<40.2$ & $<40.3$ & $<40.2$ & $<39.1$ & 5.55 & 6.31 & 5.82 & 4.58 \\
\hline $\mathrm{Ba}$ & 177 & 189 & 167 & 181 & 193 & 198 & 195 & 191 & 5.35 & 5.59 & 5.39 & 4.56 \\
\hline $\mathrm{Be}$ & 1.60 & 1.67 & 1.47 & 1.60 & 1.59 & 1.60 & 1.59 & 1.55 & $<0.12$ & $<0.12$ & $<0.12$ & $<0.11$ \\
\hline $\mathrm{Ca}$ & 2,330 & 2,500 & 2,250 & 2,400 & 2,750 & 2,670 & 2,780 & 2,650 & $1,278.24$ & $1,371.09$ & $1,318.81$ & $1,139.94$ \\
\hline $\mathrm{Cd}$ & 88.9 & 95.9 & 85.3 & 92.6 & 84.7 & 88.3 & 90.7 & 86.2 & 20.21 & 21.68 & 20.99 & 18.07 \\
\hline $\mathrm{Ce}$ & 215 & 231 & 206 & 226 & 249 & 265 & 262 & 219 & $<11.95$ & $<11.78$ & $<11.94$ & $<10.79$ \\
\hline Co & 23.6 & 25.6 & 22.2 & 24.3 & 24.8 & 23.9 & 25.3 & 25.7 & 3.15 & 3.63 & 3.35 & 2.83 \\
\hline $\mathrm{Cr}$ & 161 & 173 & 153 & 168 & 217 & 250 & 277 & 260 & 24.38 & 26.37 & 25.15 & 21.83 \\
\hline
\end{tabular}


SRNL-STI-2011-00622

Revision 0

\begin{tabular}{|c|c|c|c|c|c|c|c|c|c|c|c|c|}
\hline & \multicolumn{4}{|c|}{ Aqua regia ICP-AES Slurry, mg/kg slurry } & \multicolumn{4}{|c|}{ Peroxide Fusion ICP-AES Slurry, mg/kg slurry } & \multicolumn{4}{|c|}{ ICP-AES Supernate, mg/L } \\
\hline & 1 & 2 & 3 & 4 & 1 & 2 & 3 & 4 & 1 & 2 & 3 & 4 \\
\hline 3002 & 92314 & 92315 & 92316 & 92317 & 92322 & 92323 & 92324 & 92325 & 92441 & 92442 & 92443 & 92444 \\
\hline Units & $\mathrm{ug} / \mathrm{g}$ & $\mathrm{ug} / \mathrm{g}$ & $\mathrm{ug} / \mathrm{g}$ & $\mathrm{ug} / \mathrm{g}$ & $\mathrm{ug} / \mathrm{g}$ & $\mathrm{ug} / \mathrm{g}$ & $\mathrm{ug} / \mathrm{g}$ & $\mathrm{ug} / \mathrm{g}$ & $\mathrm{mg} / \mathrm{L}$ & $\mathrm{mg} / \mathrm{L}$ & $\mathrm{mg} / \mathrm{L}$ & $\mathrm{mg} / \mathrm{L}$ \\
\hline $\mathrm{Cu}$ & 97.1 & 106.0 & 92.8 & 101.0 & 69.3 & 66.8 & 68.5 & 69.0 & $<1.25$ & $<1.23$ & $<1.25$ & $<1.13$ \\
\hline $\mathrm{Fe}$ & 27,700 & 29,600 & 26,700 & 28,500 & 28,200 & 28,600 & 29,200 & 28,100 & 191.84 & 205.08 & 197.43 & 170.90 \\
\hline $\mathrm{Gd}$ & 165 & 177 & 157 & 169 & 127 & 113 & 86 & 97 & 61.43 & 65.63 & 63.37 & 54.04 \\
\hline $\mathrm{K}$ & $<59$ & $<81$ & $<67$ & $<73$ & $<511$ & $<512$ & $<511$ & $<497$ & 83.23 & 88.67 & 87.33 & 82.68 \\
\hline $\mathrm{La}$ & 128 & 133 & 125 & 130 & 137 & 132 & 139 & 129 & 19.76 & 20.90 & 20.00 & 17.09 \\
\hline $\mathrm{Li}$ & 59.4 & 64.3 & 56.2 & 60.9 & 82.1 & 83.5 & 83.6 & 76.2 & 5.65 & 7.05 & 5.27 & 4.97 \\
\hline $\mathrm{Mg}$ & 1,130 & 1,220 & 1,080 & 1,170 & 1,200 & 1,190 & 1,220 & 1,180 & 729.29 & 781.25 & 750.50 & 647.82 \\
\hline $\mathrm{Mn}$ & 6,530 & 7,040 & 6,260 & 6,740 & 6,750 & 6,830 & 6,900 & 6,680 & $3,507.73$ & $3,750.00$ & $3,603.96$ & $3,095.92$ \\
\hline Mo & $<15.8$ & $<16.9$ & $<14.4$ & $<14.6$ & $<53.4$ & $<53.4$ & $<53.3$ & $<51.9$ & $<12.23$ & $<12.05$ & $<12.22$ & $<11.04$ \\
\hline $\mathrm{Na}$ & 27,600 & 29,300 & 26,400 & 27,900 & NM & NM & NM & NM & 29,330 & 31,445 & 30,297 & 26,127 \\
\hline $\mathrm{Ni}$ & $<4,230$ & $<4,570$ & $<4,100$ & $<4,370$ & $<4,400$ & $<4,410$ & $<4,530$ & $<4,360$ & 370.59 & 398.44 & 382.18 & 329.28 \\
\hline $\mathrm{P}$ & $<203$ & $<180$ & $<275$ & $<232$ & $<173$ & $<213$ & $<260$ & $<168$ & $<32.50$ & $<32.03$ & $<32.48$ & $<29.35$ \\
\hline $\mathrm{Pb}$ & $<65$ & $<71$ & $<63$ & $<68$ & $<1,050$ & $<1,050$ & $<1,050$ & $<1,020$ & $<14.19$ & $<13.98$ & $<14.18$ & $<12.81$ \\
\hline $\mathrm{S}$ & $<259$ & $<250$ & $<145$ & $<167$ & $<1,490$ & $<1,500$ & $<1,490$ & $<1,450$ & 229.89 & 146.48 & 217.82 & 141.55 \\
\hline $\mathrm{Sb}$ & 249 & 247 & 248 & 252 & 212 & 213 & 212 & 207 & $<25.37$ & $<25.00$ & $<25.35$ & $<22.91$ \\
\hline $\mathrm{Sn}$ & NM & NM & NM & NM & 1660 & 1600 & 1600 & 1520 & 59.85 & 66.80 & 62.38 & 50.64 \\
\hline $\mathrm{Sn}$ & $<98$ & $<98$ & $<98$ & $<99$ & $<112$ & $<112$ & $<112$ & $<109$ & $<11.12$ & $<10.96$ & $<11.11$ & $<10.04$ \\
\hline $\mathrm{Sr}$ & 89.8 & 95.1 & 84.4 & 91.4 & 94.9 & 97.7 & 96.6 & 94.1 & 50.54 & 54.10 & 52.08 & 44.92 \\
\hline $\mathrm{Th}$ & 202 & 214 & 193 & 209 & 240 & 216 & 235 & 217 & $<10.60$ & $<10.45$ & $<10.59$ & $<9.57$ \\
\hline $\mathrm{Ti}$ & 31.4 & 32.5 & 29.1 & 32.2 & 41.6 & 49.7 & 46.0 & 45.2 & 2.28 & 2.34 & 2.36 & 1.97 \\
\hline $\mathrm{U}$ & 8,770 & 9,760 & 8,660 & 9,180 & 8,990 & 8,640 & 9,050 & 8,660 & $3,151.01$ & $3,378.91$ & $3,227.72$ & $2,809.59$ \\
\hline $\mathrm{V}$ & $<9.15$ & $<9.11$ & $<9.12$ & $<9.26$ & $<9.36$ & $<9.37$ & $<9.35$ & $<9.11$ & $<0.93$ & $<0.92$ & $<0.93$ & $<0.84$ \\
\hline $\mathrm{Zn}$ & 97.5 & 107.0 & 93.9 & 103.0 & 99.8 & 103.0 & 99.1 & 93.8 & 2.66 & 2.75 & 2.65 & 2.25 \\
\hline
\end{tabular}


SRNL-STI-2011-00622

Revision 0

Table D - 6. SRAT Product pH 3 ICP-AES

\begin{tabular}{|c|c|c|c|c|c|c|c|c|c|c|c|c|}
\hline & \multicolumn{4}{|c|}{ Aqua regia ICP-AES Slurry, mg/kg } & \multicolumn{4}{|c|}{ Peroxide Fusion ICP-AES Slurry, mg/kg } & \multicolumn{4}{|c|}{ ICP-AES Supernate, $\mathrm{mg} / \mathrm{L}$} \\
\hline & 1 & 2 & 3 & 4 & 1 & 2 & 3 & 4 & 1 & 2 & 3 & 4 \\
\hline 3002 & 92330 & 92331 & 92332 & 92333 & 92345 & 92346 & 92347 & 92348 & 92265 & 92266 & 92267 & 92268 \\
\hline Units & $\mathrm{ug} / \mathrm{g}$ & $\mathrm{ug} / \mathrm{g}$ & $\mathrm{ug} / \mathrm{g}$ & $\mathrm{ug} / \mathrm{g}$ & $\mathrm{ug} / \mathrm{g}$ & $\mathrm{ug} / \mathrm{g}$ & $\mathrm{ug} / \mathrm{g}$ & $\mathrm{ug} / \mathrm{g}$ & $\mathrm{mg} / \mathrm{L}$ & $\mathrm{mg} / \mathrm{L}$ & $\mathrm{mg} / \mathrm{L}$ & $\mathrm{mg} / \mathrm{L}$ \\
\hline $\mathrm{Ag}$ & $<29$ & $<28$ & $<29$ & $<27$ & 285 & 282 & 281 & 287 & $<27.06$ & $<27.16$ & $<27.46$ & $<28.07$ \\
\hline $\mathrm{Al}$ & 6,060 & 5,680 & 5,410 & 6,060 & 15,500 & 14,300 & 14,700 & 16,300 & 1,436 & 1,283 & 1,346 & 1,423 \\
\hline B & $<40.2$ & $<39.7$ & $<40.0$ & $<38.2$ & $<39.9$ & $<39.6$ & $<39.4$ & $<40.3$ & 6.20 & 5.04 & 5.28 & 5.83 \\
\hline $\mathrm{Ba}$ & 176 & 176 & 174 & 175 & 193 & 177 & 183 & 204 & 5.41 & 4.55 & 4.86 & 5.13 \\
\hline $\mathrm{Be}$ & 1.45 & 1.46 & 1.46 & 1.49 & 1.58 & 1.57 & 1.56 & 1.60 & $<0.11$ & $<0.11$ & $<0.11$ & $<0.12$ \\
\hline $\mathrm{Ca}$ & 2,270 & 2,290 & 2,270 & 2,280 & 2,720 & 2,440 & 2,460 & 2,930 & 2,161 & 1,924 & 2,021 & 2,125 \\
\hline $\mathrm{Cd}$ & 83.2 & 82.9 & 82.7 & 83.3 & 89.3 & 81.8 & 84.5 & 95.4 & 36.45 & 32.44 & 33.75 & 35.87 \\
\hline $\mathrm{Ce}$ & 213 & 219 & 212 & 216 & 184 & 184 & 163 & 222 & 13.28 & 13.33 & 13.48 & 13.78 \\
\hline $\mathrm{Co}$ & 21.3 & 22.3 & 21.8 & 22.3 & 25.8 & 24.8 & 25.9 & 27.7 & 6.37 & 5.55 & 5.68 & 5.93 \\
\hline $\mathrm{Cr}$ & 159 & 156 & 154 & 155 & 172 & 159 & 164 & 183 & 36.45 & 32.44 & 33.94 & 35.87 \\
\hline $\mathrm{Cu}$ & 97.9 & 97.9 & 96.8 & 98.2 & 70.7 & 70.8 & 68.5 & 76.6 & $<11.84$ & $<11.88$ & $<12.01$ & $<12.28$ \\
\hline $\mathrm{Fe}$ & 26,600 & 26,700 & 26,600 & 26,500 & 28,600 & 26,400 & 27,400 & 30,200 & 499.81 & 443.23 & 465.29 & 491.23 \\
\hline $\mathrm{Gd}$ & 166 & 165 & 165 & 167 & 125 & 115 & 108 & 133 & 132.66 & 118.63 & 123.00 & 130.41 \\
\hline $\mathrm{K}$ & $<90$ & $<103$ & $<95$ & $<92$ & $<507$ & $<503$ & $<501$ & $<512$ & 104.66 & 104.49 & 106.60 & 107.02 \\
\hline $\mathrm{La}$ & 127 & 121 & 123 & 123 & 128 & 118 & 122 & 145 & 53.55 & 47.72 & 49.58 & 52.63 \\
\hline $\mathrm{Li}$ & 60.9 & 60.3 & 59.7 & 59.8 & 76.7 & 64.9 & 74.1 & 86.4 & 11.46 & 8.85 & 10.18 & 11.03 \\
\hline $\mathrm{Mg}$ & 1,090 & 1,110 & 1,100 & 1,110 & 1,180 & 1,080 & 1,120 & 1,260 & 839.91 & 748.77 & 785.66 & 832.36 \\
\hline $\mathrm{Mn}$ & 6,310 & 6,380 & 6,350 & 6,400 & 6,840 & 6,300 & 6,520 & 7,180 & 4,247 & 3,791 & 3,966 & 4,191 \\
\hline Mo & $<16.1$ & $<14.0$ & $<15.3$ & $<15.7$ & $<53.0$ & $<52.5$ & $<52.3$ & $<53.5$ & 7.25 & 5.83 & 7.25 & 6.67 \\
\hline $\mathrm{Na}$ & 27,500 & 27,400 & 27,400 & 27,400 & $\mathrm{NM}$ & NM & NM & NM & 30,064 & 31,120 & 28,223 & 28,070 \\
\hline $\mathrm{Ni}$ & $<4,100$ & $<4,140$ & $<4,080$ & $<4,120$ & $<4,590$ & $<4,200$ & $<4,350$ & $<4,840$ & 528.00 & 469.63 & 493.90 & 520.47 \\
\hline $\mathrm{P}$ & $<275$ & $<274$ & $<207$ & $<250$ & $<283$ & $<170$ & $<169$ & $<255$ & 30.82 & 30.93 & 31.27 & 31.97 \\
\hline $\mathrm{Pb}$ & $<55$ & $<60$ & $<58$ & $<60$ & $<1,040$ & $<1,040$ & $<1,030$ & $<1,050$ & $<13.45$ & $<13.50$ & $<13.65$ & $<13.96$ \\
\hline $\mathrm{S}$ & $<217$ & $<147$ & $<154$ & $<191$ & $<1,480$ & $<1,470$ & $<1,460$ & $<1,500$ & 255.54 & 141.46 & 244.09 & 214.42 \\
\hline $\mathrm{Sb}$ & 254 & 251 & 253 & 242 & 211 & 209 & 208 & 213 & $<24.05$ & $<24.14$ & $<24.41$ & $<24.95$ \\
\hline $\mathrm{Sn}$ & & & & & 1650 & 1520 & 1560 & 1740 & 306.28 & 267.82 & 272.69 & 290.45 \\
\hline Sn & $<100$ & $<99$ & $<100$ & $<95$ & $<111$ & $<110$ & $<109$ & $<112$ & $<10.54$ & $<10.58$ & $<10.70$ & $<10.94$ \\
\hline
\end{tabular}


SRNL-STI-2011-00622

Revision 0

\begin{tabular}{|c|c|c|c|c|c|c|c|c|c|c|c|c|}
\hline & \multicolumn{4}{|c|}{ Aqua regia ICP-AES Slurry, mg/kg } & \multicolumn{4}{|c|}{ Peroxide Fusion ICP-AES Slurry, mg/kg } & \multicolumn{4}{|c|}{ ICP-AES Supernate, $\mathrm{mg} / \mathrm{L}$} \\
\hline & 1 & 2 & 3 & 4 & 1 & 2 & 3 & 4 & 1 & 2 & 3 & 4 \\
\hline $\begin{array}{l}3002 \\
\text { Units }\end{array}$ & $\begin{array}{c}92330 \\
\mathrm{ug} / \mathrm{g}\end{array}$ & $\begin{array}{c}92331 \\
\mathrm{ug} / \mathrm{g}\end{array}$ & $\begin{array}{c}92332 \\
\text { ug/g }\end{array}$ & $\begin{array}{c}92333 \\
\mathrm{ug} / \mathrm{g}\end{array}$ & $\begin{array}{c}92345 \\
\mathrm{ug} / \mathrm{g}\end{array}$ & $\begin{array}{c}92346 \\
\mathrm{ug} / \mathrm{g}\end{array}$ & $\begin{array}{c}92347 \\
\mathrm{ug} / \mathrm{g}\end{array}$ & $\begin{array}{c}92348 \\
\mathrm{ug} / \mathrm{g}\end{array}$ & $\begin{array}{c}92265 \\
\mathrm{mg} / \mathrm{L}\end{array}$ & $\begin{array}{c}92266 \\
\mathrm{mg} / \mathrm{L}\end{array}$ & $\begin{array}{c}92267 \\
\mathrm{mg} / \mathrm{L}\end{array}$ & $\begin{array}{c}92268 \\
\mathrm{mg} / \mathrm{L}\end{array}$ \\
\hline $\mathrm{Sr}$ & 88.2 & 88.5 & 90.8 & 88.1 & 87.5 & 80.4 & 82.4 & 98.0 & 66.89 & 59.79 & 62.55 & 66.08 \\
\hline Th & 206 & 206 & 201 & 204 & 231 & 206 & 209 & 253 & $<102.97$ & $<103.36$ & $<104.50$ & $<106.82$ \\
\hline $\mathrm{Ti}$ & 29.2 & 28.3 & 33.1 & 28.3 & 38.7 & 35.9 & 37.1 & 40.5 & $<0.71$ & $<0.72$ & $<0.72$ & $<0.74$ \\
\hline $\mathrm{U}$ & 8,940 & 9,340 & 9,190 & 9,160 & 8,360 & 8,000 & 7,950 & 9,160 & 7,704 & 7,865 & 7,265 & 7,290 \\
\hline $\mathrm{V}$ & $<9.36$ & $<9.24$ & $<9.30$ & $<8.89$ & $<9.29$ & $<9.22$ & $<9.17$ & $<9.38$ & $<0.88$ & $<0.89$ & $<0.90$ & $<0.92$ \\
\hline $\mathrm{Zn}$ & 90.5 & 91.7 & 91.3 & 92.1 & 98.2 & 86.9 & 94.0 & 107.0 & 5.20 & 4.45 & 5.09 & 5.07 \\
\hline
\end{tabular}

Table D - 7. SRAT Product pH 2 ICP-AES

\begin{tabular}{|c|c|c|c|c|c|c|c|c|c|c|c|c|}
\hline & \multicolumn{4}{|c|}{ Aqua regia ICP-AES Slurry, $\mathrm{mg} / \mathrm{kg}$} & \multicolumn{8}{|c|}{ Peroxide Fusion ICP-AES Slurry, mg/kg ICP-AES Supernate, mg/L } \\
\hline & 1 & 2 & 3 & 4 & 1 & 2 & 3 & 4 & 1 & 2 & 3 & 4 \\
\hline 3002 & 92359 & 92360 & 92361 & 92362 & 92352 & 92353 & 92354 & 92355 & 92485 & 92486 & 92487 & 92488 \\
\hline Units & $\mathrm{ug} / \mathrm{g}$ & $\mathrm{ug} / \mathrm{g}$ & $\mathrm{ug} / \mathrm{g}$ & $\mathrm{ug} / \mathrm{g}$ & $\mathrm{ug} / \mathrm{g}$ & $\mathrm{ug} / \mathrm{g}$ & $\mathrm{ug} / \mathrm{g}$ & $\mathrm{ug} / \mathrm{g}$ & $\mathrm{mg} / \mathrm{L}$ & $\mathrm{mg} / \mathrm{L}$ & $\mathrm{mg} / \mathrm{L}$ & $\mathrm{mg} / \mathrm{L}$ \\
\hline $\mathrm{Ag}$ & $<28$ & $<28$ & $<28$ & $<28$ & 282 & 285 & 277 & 278 & $<2.79$ & $<2.80$ & $<2.86$ & $<2.84$ \\
\hline $\mathrm{Al}$ & 13,000 & 14,000 & 13,800 & 14,100 & 13000 & 14000 & 13800 & 14100 & 1,634 & 1,620 & 1,671 & 1,515 \\
\hline $\mathrm{B}$ & $<39.3$ & $<39.9$ & $<39.6$ & $<39.3$ & 39.5 & 40 & 38.9 & 39 & 4.74 & 4.50 & 4.75 & 4.19 \\
\hline $\mathrm{Ba}$ & 170 & 172 & 155 & 167 & 161 & 170 & 166 & 173 & 6.13 & 6.09 & 6.30 & 5.71 \\
\hline $\mathrm{Be}$ & 1.56 & 1.58 & 1.57 & 1.56 & 1.57 & 1.78 & 1.54 & 1.74 & $<0.12$ & $<0.12$ & $<0.12$ & $<0.12$ \\
\hline $\mathrm{Ca}$ & 2,190 & 2,250 & 2,000 & 2,150 & 2360 & 2420 & 2380 & 2320 & 2,186 & 2,181 & 2,247 & 2,035 \\
\hline $\mathrm{Cd}$ & 79.8 & 81.7 & 74.6 & 78.6 & 71.8 & 76.6 & 79.3 & 78.3 & 35.8 & 35.8 & 37.0 & 33.4 \\
\hline $\mathrm{Ce}$ & 215 & 189 & 198 & 211 & 224 & 215 & 223 & 213 & $<20.5$ & $<20.6$ & $<21.1$ & $<20.9$ \\
\hline $\mathrm{Co}$ & 23.8 & 20.6 & 21.6 & 22.8 & 20.5 & 20.6 & 20 & 23.5 & 7.56 & 7.83 & 7.68 & 7.25 \\
\hline $\mathrm{Cr}$ & 156 & 159 & 147 & 154 & 148 & 151 & 152 & 154 & 36.4 & 36.2 & 37.0 & 34.0 \\
\hline $\mathrm{Cu}$ & 65.4 & 67.7 & 60.8 & 65.2 & 61.6 & 62.8 & 62.4 & 65 & $<1.22$ & $<1.23$ & $<1.25$ & $<1.24$ \\
\hline $\mathrm{Fe}$ & 25,800 & 26,200 & 23,600 & 25,200 & 24000 & 25500 & 25000 & 25700 & 638 & 637 & 654 & 595 \\
\hline $\mathrm{Gd}$ & 175 & 152 & 161 & 168 & 120 & 130 & 122 & 114 & 128 & 127 & 130 & 119 \\
\hline $\mathrm{K}$ & $<119$ & $<105$ & $<107$ & $<113$ & 502 & 508 & 494 & 495 & 87.2 & 104.4 & 96.9 & 92.3 \\
\hline $\mathrm{La}$ & 132 & 116 & 122 & 129 & 112 & 122 & 118 & 120 & 47.2 & 47.9 & 49.1 & 44.6 \\
\hline
\end{tabular}


SRNL-STI-2011-00622

Revision 0

\begin{tabular}{|c|c|c|c|c|c|c|c|c|c|c|c|c|}
\hline & \multicolumn{4}{|c|}{ Aqua regia ICP-AES Slurry, mg/kg } & \multicolumn{4}{|c|}{ Peroxide Fusion ICP-AES Slurry, mg/kg } & \multicolumn{4}{|c|}{ ICP-AES Supernate, mg/L } \\
\hline & 1 & 2 & 3 & 4 & 1 & 2 & 3 & 4 & 1 & 2 & 3 & 4 \\
\hline 3002 & 92359 & 92360 & 92361 & 92362 & 92352 & 92353 & 92354 & 92355 & 92485 & 92486 & 92487 & 92488 \\
\hline Units & $\mathrm{ug} / \mathrm{g}$ & $\mathrm{ug} / \mathrm{g}$ & $\mathrm{ug} / \mathrm{g}$ & $\mathrm{ug} / \mathrm{g}$ & $\mathrm{ug} / \mathrm{g}$ & $\mathrm{ug} / \mathrm{g}$ & $\mathrm{ug} / \mathrm{g}$ & $\mathrm{ug} / \mathrm{g}$ & $\mathrm{mg} / \mathrm{L}$ & $\mathrm{mg} / \mathrm{L}$ & $\mathrm{mg} / \mathrm{L}$ & $\mathrm{mg} / \mathrm{L}$ \\
\hline $\mathrm{Li}$ & 59.6 & 52.1 & 55.7 & 58.3 & 63.8 & 68.5 & 67 & 80.4 & 9.63 & 9.56 & 10.24 & 8.22 \\
\hline $\mathrm{Mg}$ & 1,080 & 1,110 & 989 & 1,060 & 984 & 1050 & 1030 & 1040 & 805 & 802 & 827 & 753 \\
\hline $\mathrm{Mn}$ & 6,260 & 6,440 & 5,720 & 6,140 & 5720 & 6090 & 6000 & 6130 & 4,043 & 4,030 & 4,157 & 3,773 \\
\hline Mo & $<24.0$ & $<24.4$ & $<24.2$ & $<24.0$ & 52.4 & 53.1 & 51.6 & 51.7 & $<11.9$ & $<12.0$ & $<12.3$ & $<12.2$ \\
\hline $\mathrm{Na}$ & 26,700 & 27,500 & 24,400 & 26,100 & NM & NM & NM & NM & 29,207 & 29,011 & 29,833 & 27,262 \\
\hline $\mathrm{Ni}$ & $<4,070$ & $<4,160$ & $<3,710$ & $<3,980$ & 3910 & 4160 & 4100 & 4210 & 557 & 557 & 573 & 522 \\
\hline $\mathrm{P}$ & $<138$ & $<238$ & $<165$ & $<203$ & 169 & 171 & 167 & 167 & $<16.8$ & $<16.9$ & $<17.2$ & $<17.1$ \\
\hline $\mathrm{Pb}$ & $<51$ & $<47$ & $<48$ & $<52$ & 140 & 142 & 138 & 138 & $<13.8$ & $<13.9$ & $<14.2$ & $<14.1$ \\
\hline $\mathrm{S}$ & $<280$ & $<263$ & $<278$ & $<236$ & 1470 & 1490 & 1470 & 1450 & 145 & 146 & 172 & 148 \\
\hline $\mathrm{Sb}$ & 104 & 105 & 105 & 104 & 209 & 211 & 205 & 208 & $<24.8$ & $<24.9$ & $<25.5$ & $<25.3$ \\
\hline $\mathrm{Sn}$ & $<467$ & $<423$ & $<438$ & $<454$ & 1370 & 1470 & 1380 & 1440 & 111 & 108 & 109 & 89 \\
\hline $\mathrm{Sn}$ & 109.0 & 111.0 & 110.0 & 109.0 & 110 & 111 & 108 & 108 & $<10.9$ & $<10.9$ & $<11.2$ & $<11.1$ \\
\hline $\mathrm{Sr}$ & 91 & 81 & 85 & 89 & 78.8 & 81.9 & 90.5 & 91.8 & 71.0 & 70.5 & 72.6 & 65.8 \\
\hline Th & 198.0 & 176.0 & 203.0 & 212.0 & 214 & 219 & 205 & 223 & $<41.4$ & $<41.7$ & $<42.6$ & $<42.3$ \\
\hline $\mathrm{Ti}$ & 32 & 32 & 28 & 31 & 33.7 & 33.7 & 44.9 & 45.3 & $<7.35$ & $<7.40$ & $<7.56$ & $<7.51$ \\
\hline $\mathrm{U}$ & $<9,040.00$ & $<9,300.00$ & $<8,000.00$ & $<8,510.00$ & 7530 & 8280 & 7920 & 7870 & 7,253 & 7,204 & 7,399 & 6,717 \\
\hline $\mathrm{V}$ & 9.2 & 9.3 & 9.2 & 9.1 & 9.2 & 9.31 & 9.05 & 9.06 & $<1.82$ & $<1.83$ & $<1.87$ & $<1.86$ \\
\hline $\mathrm{Zn}$ & 95.2 & 84.0 & 88.9 & 93.6 & 86.5 & 88.5 & 90.3 & 94.4 & 7.10 & 6.78 & 6.78 & 6.34 \\
\hline
\end{tabular}


SRNL-STI-2011-00622

Revision 0

Table D - 8. SRAT Product pH 1 ICP-AES

\begin{tabular}{|c|c|c|c|c|c|c|c|c|c|c|c|c|}
\hline \multicolumn{5}{|c|}{ Aqua regia ICP-AES Slurry, mg/kg } & \multicolumn{4}{|c|}{ Peroxide Fusion ICP-AES Slurry, mg/kg } & \multicolumn{4}{|c|}{ ICP-AES Supernate, $\mathrm{mg} / \mathrm{L}$} \\
\hline & 1 & 2 & 3 & 4 & 1 & 2 & 3 & 4 & 1 & 2 & 3 & 4 \\
\hline 3002 & 92366 & 92367 & 92368 & 92369 & 92373 & 92374 & 92375 & 92376 & 92556 & 92557 & 92558 & 92559 \\
\hline Units & $\mathrm{ug} / \mathrm{g}$ & $\mathrm{ug} / \mathrm{g}$ & $\mathrm{ug} / \mathrm{g}$ & $\mathrm{ug} / \mathrm{g}$ & $\mathrm{ug} / \mathrm{g}$ & $\mathrm{ug} / \mathrm{g}$ & $\mathrm{ug} / \mathrm{g}$ & $\mathrm{ug} / \mathrm{g}$ & $\mathrm{mg} / \mathrm{L}$ & $\mathrm{mg} / \mathrm{L}$ & $\mathrm{mg} / \mathrm{L}$ & $\mathrm{mg} / \mathrm{L}$ \\
\hline $\mathrm{Ag}$ & $<28$ & $<29$ & $<28$ & $<28$ & 283 & 288 & 282 & 280 & $<2.86$ & $<2.84$ & $<2.82$ & $<2.85$ \\
\hline $\mathrm{Al}$ & 9,410 & 7,940 & 7,520 & 12,000 & 13,700 & 14,500 & 13,700 & 14,400 & 1,593 & 1,756 & 1,690 & 1,560 \\
\hline B & $<39.6$ & $<40.4$ & $<39.6$ & $<39.6$ & $<39.7$ & $<40.4$ & $<39.5$ & $<39.3$ & 5.54 & 5.14 & 4.86 & 5.05 \\
\hline $\mathrm{Ba}$ & 170 & 167 & 168 & 169 & 170 & 177 & 164 & 175 & $<10.4$ & $<11.4$ & $<11.0$ & $<10.2$ \\
\hline $\mathrm{Be}$ & 1.51 & 1.50 & 1.49 & 1.51 & 1.57 & 1.60 & 1.56 & 1.56 & 0.12 & 0.12 & 0.12 & 0.12 \\
\hline $\mathrm{Ca}$ & 2,120 & 2,090 & 2,120 & 2,130 & 2,380 & 2,520 & 2,430 & 2,380 & 1,984 & 2,193 & 2,098 & 1,943 \\
\hline $\mathrm{Cd}$ & 79.2 & 76.9 & 78.0 & 78.2 & 77.8 & 82.7 & 79.0 & 79.5 & 34.7 & 38.3 & 37.1 & 33.9 \\
\hline $\mathrm{Ce}$ & 205 & 200 & 205 & 208 & 172 & 184 & 182 & 189 & $<21.0$ & $<20.9$ & $<20.8$ & $<21.0$ \\
\hline $\mathrm{Co}$ & 21.1 & 20.4 & 21.0 & 20.8 & 26.3 & 29.0 & 28.5 & 24.5 & 7.26 & 8.26 & 7.41 & 6.89 \\
\hline $\mathrm{Cr}$ & 152 & 149 & 152 & 150 & 162 & 171 & 164 & 169 & 34.52 & 38.13 & 36.47 & 33.86 \\
\hline $\mathrm{Cu}$ & 94.1 & 92.1 & 93.5 & 92.8 & 66.2 & 66.7 & 66.9 & 68.5 & $<1.25$ & $<1.24$ & $<1.24$ & $<1.25$ \\
\hline $\mathrm{Fe}$ & 25,300 & 24,700 & 25,000 & 25,100 & 25,500 & 26,800 & 25,300 & 26,600 & 607 & 670 & 647 & 594 \\
\hline $\mathrm{Gd}$ & 163 & 158 & 164 & 165 & 113 & 127 & 124 & 119 & 121 & 134 & 128 & 118 \\
\hline $\mathrm{K}$ & $<107$ & $<102$ & $<108$ & $<107$ & $<504$ & $<513$ & $<502$ & $<500$ & 91.9 & 94.0 & 87.6 & 90.3 \\
\hline $\mathrm{La}$ & 140 & 136 & 140 & 140 & 117 & 127 & 121 & 124 & 51.6 & 57.1 & 54.1 & 50.5 \\
\hline $\mathrm{Li}$ & 54.5 & 53.0 & 54.3 & 54.6 & 68.0 & 106.0 & 87.6 & 91.1 & 11.1 & 12.4 & 12.3 & 11.0 \\
\hline $\mathrm{Mg}$ & 1,040 & 1,020 & 1,040 & 1,040 & 1,020 & 1,080 & 1,030 & 1,060 & 738 & 814 & 782 & 723 \\
\hline $\mathrm{Mn}$ & 5,930 & 5,770 & 5,930 & 5,940 & 5,950 & 6,290 & 5,950 & 6,240 & 3,690 & 4,070 & 3,902 & 3,604 \\
\hline Mo & $<16.5$ & $<12.2$ & $<16.6$ & $<16.1$ & $<52.7$ & $<53.5$ & $<52.4$ & $<52.2$ & $<12.2$ & $<12.2$ & $<12.1$ & $<12.2$ \\
\hline $\mathrm{Na}$ & 25,300 & 24,600 & 25,100 & 25,200 & NM & NM & $\mathrm{NM}^{\prime}$ & NM & 26,190 & 28,842 & 27,647 & 25,545 \\
\hline $\mathrm{Ni}$ & $<4,070$ & $<3,970$ & $<4,010$ & $<4,060$ & $<4,120$ & $<4,390$ & $<4,120$ & $<4,330$ & 528 & 587 & 559 & 517 \\
\hline $\mathrm{P}$ & $<186$ & $<120$ & $<184$ & $<180$ & $<170$ & $<173$ & $<169$ & $<169$ & 74.4 & 71.5 & 63.1 & 60.8 \\
\hline $\mathrm{Pb}$ & $<<52$ & $<50$ & $<49$ & $<52$ & $<141$ & $<143$ & $<140$ & $<139$ & $<14.2$ & $<14.1$ & $<14.0$ & $<14.2$ \\
\hline $\mathrm{S}$ & $<195$ & $<309$ & $<246$ & $<277$ & $<1,470$ & $<1,500$ & $<1,470$ & $<1,460$ & 176 & 148 & 158 & 152 \\
\hline $\mathrm{Sb}$ & 251 & 255 & 250 & 250 & 209 & 213 & 208 & 208 & $<25.4$ & $<25.3$ & $<25.1$ & $<25.3$ \\
\hline $\mathrm{Sn}$ & NM & NM & NM & NM & 1470 & 1530 & 1400 & 1530 & 69.6 & 81.8 & 71.8 & 61.6 \\
\hline Sn & $<99$ & $<101$ & $<99$ & $<99$ & $<110$ & $<112$ & $<110$ & $<109$ & $<11.1$ & $<11.1$ & $<11.0$ & $<11.1$ \\
\hline
\end{tabular}


SRNL-STI-2011-00622

Revision 0

\begin{tabular}{|c|c|c|c|c|c|c|c|c|c|c|c|c|}
\hline & \multicolumn{4}{|c|}{ Aqua regia ICP-AES Slurry, $\mathrm{mg} / \mathrm{kg}$} & \multicolumn{4}{|c|}{ Peroxide Fusion ICP-AES Slurry, mg/kg } & \multicolumn{4}{|c|}{ ICP-AES Supernate, mg/L } \\
\hline & 1 & 2 & 3 & 4 & 1 & 2 & 3 & 4 & 1 & 2 & 3 & 4 \\
\hline 3002 & 92366 & 92367 & 92368 & 92369 & 92373 & 92374 & 92375 & 92376 & 92556 & 92557 & 92558 & 92559 \\
\hline Units & $\mathrm{ug} / \mathrm{g}$ & $\mathrm{ug} / \mathrm{g}$ & $\mathrm{ug} / \mathrm{g}$ & $\mathrm{ug} / \mathrm{g}$ & $\mathrm{ug} / \mathrm{g}$ & $\mathrm{ug} / \mathrm{g}$ & $\mathrm{ug} / \mathrm{g}$ & $\mathrm{ug} / \mathrm{g}$ & $\mathrm{mg} / \mathrm{L}$ & $\mathrm{mg} / \mathrm{L}$ & $\mathrm{mg} / \mathrm{L}$ & $\mathrm{mg} / \mathrm{L}$ \\
\hline $\mathrm{Sr}$ & 86.2 & 83.4 & 85.2 & 85.8 & 78.4 & 84.5 & 86.7 & 80.4 & 64.7 & 71.5 & 68.6 & 63.6 \\
\hline Th & 287 & 281 & 288 & 288 & 206 & 217 & 203 & 200 & $<42.5$ & $<42.3$ & $<42.0$ & $<42.4$ \\
\hline $\mathrm{Ti}$ & 28.1 & 27.5 & 27.5 & 27.8 & 36.5 & 38.4 & 42.0 & 36.8 & $<7.54$ & $<7.51$ & $<7.45$ & $<7.52$ \\
\hline $\mathrm{U}$ & 8,380 & 8,210 & 8,470 & 8,340 & 7,820 & 8,220 & 7,880 & 8,180 & 7,143 & 7,882 & 7,569 & 7,010 \\
\hline $\mathrm{V}$ & $<9.22$ & $<9.40$ & $<9.21$ & $<9.21$ & $<9.23$ & $<9.39$ & $<9.19$ & $<9.15$ & $<1.87$ & $<1.86$ & $<1.84$ & $<1.86$ \\
\hline $\mathrm{Zn}$ & 83.6 & 81.9 & 82.5 & 83.2 & 96.9 & 102.0 & 91.9 & 104.0 & 6.69 & 7.53 & 7.06 & 6.30 \\
\hline
\end{tabular}


SRNL-STI-2011-00622

Revision 0

Table D - 9. SRAT Receipt ICP-MS

\begin{tabular}{|c|c|c|c|c|c|c|c|c|}
\hline \multirow[b]{2}{*}{$\begin{array}{c}3002 \\
\mathrm{~m} / \mathrm{z}\end{array}$} & \multicolumn{4}{|c|}{ Aqua regia ICP-MS, mg/kg slurry basis } & \multicolumn{4}{|c|}{ Supernate Basis, mg/L } \\
\hline & $\begin{array}{c}1 \\
92299 \\
\mu \mathrm{g} / \mathrm{g}\end{array}$ & $\begin{array}{c}1 \\
92300 \\
\mu \mathrm{g} / \mathrm{g}\end{array}$ & $\begin{array}{c}3 \\
92301 \\
\mu \mathrm{g} / \mathrm{g}\end{array}$ & $\begin{array}{c}4 \\
92302 \\
\mu \mathrm{g} / \mathrm{g}\end{array}$ & $\begin{array}{c}1 \\
92247 \\
\mathrm{mg} / \mathrm{L}\end{array}$ & $\begin{array}{c}2 \\
92248 \\
\mathrm{mg} / \mathrm{L}\end{array}$ & $\begin{array}{c}3 \\
92249 \\
\mathrm{mg} / \mathrm{L}\end{array}$ & $\begin{array}{c}4 \\
92250 \\
\mathrm{mg} / 1\end{array}$ \\
\hline 85 & $9.23 \mathrm{E}+00$ & $9.27 \mathrm{E}+00$ & $9.33 \mathrm{E}+00$ & $9.35 \mathrm{E}+00$ & $8.88 \mathrm{E}-02$ & $9.82 \mathrm{E}-02$ & 8.89E-02 & $8.73 \mathrm{E}-02$ \\
\hline 92 & $4.84 \mathrm{E}+01$ & $1.93 \mathrm{E}+01$ & $3.79 \mathrm{E}+01$ & $3.73 \mathrm{E}+01$ & $5.23 \mathrm{E}-02$ & $5.71 \mathrm{E}-02$ & $5.38 \mathrm{E}-02$ & 6.99E-02 \\
\hline 94 & $4.89 \mathrm{E}+01$ & $1.52 \mathrm{E}+01$ & $4.16 \mathrm{E}+01$ & $4.78 \mathrm{E}+01$ & $<4.19 \mathrm{E}-02$ & $5.90 \mathrm{E}-02$ & $4.67 \mathrm{E}-02$ & 4.39E-02 \\
\hline 95 & $2.35 \mathrm{E}+00$ & $2.32 \mathrm{E}+00$ & $3.11 \mathrm{E}+00$ & $2.34 \mathrm{E}+00$ & $3.49 \mathrm{E}-01$ & $3.74 \mathrm{E}-01$ & $3.62 \mathrm{E}-01$ & $4.24 \mathrm{E}-01$ \\
\hline 96 & $5.98 \mathrm{E}+01$ & $2.09 \mathrm{E}+01$ & $4.32 \mathrm{E}+01$ & $7.95 \mathrm{E}+01$ & 7.23E-02 & 7.08E-02 & $6.90 \mathrm{E}-02$ & $8.85 \mathrm{E}-02$ \\
\hline 97 & $1.54 \mathrm{E}+00$ & $1.55 \mathrm{E}+00$ & $1.62 \mathrm{E}+00$ & $1.56 \mathrm{E}+00$ & $2.83 \mathrm{E}-01$ & $2.96 \mathrm{E}-01$ & $3.20 \mathrm{E}-01$ & $3.50 \mathrm{E}-01$ \\
\hline 98 & $2.31 \mathrm{E}+00$ & $2.32 \mathrm{E}+00$ & $2.33 \mathrm{E}+00$ & $2.34 \mathrm{E}+00$ & $3.71 \mathrm{E}-01$ & $3.68 \mathrm{E}-01$ & $3.50 \mathrm{E}-01$ & $4.02 \mathrm{E}-01$ \\
\hline 99 & $3.84 \mathrm{E}+00$ & $3.86 \mathrm{E}+00$ & $3.89 \mathrm{E}+00$ & $3.89 \mathrm{E}+00$ & $2.75 \mathrm{E}-01$ & $2.50 \mathrm{E}-01$ & 2.66E-01 & $3.05 \mathrm{E}-01$ \\
\hline 100 & $6.92 \mathrm{E}+00$ & $6.95 \mathrm{E}+00$ & $7.00 \mathrm{E}+00$ & $7.01 \mathrm{E}+00$ & $3.25 \mathrm{E}-01$ & $3.10 \mathrm{E}-01$ & 3.13E-01 & 3.59E-01 \\
\hline 101 & $6.90 \mathrm{E}+01$ & $6.49 \mathrm{E}+01$ & $6.70 \mathrm{E}+01$ & $6.21 \mathrm{E}+01$ & $3.19 \mathrm{E}-02$ & $3.16 \mathrm{E}-02$ & $3.30 \mathrm{E}-02$ & $3.91 \mathrm{E}-02$ \\
\hline 103 & $3.56 \mathrm{E}+01$ & $3.48 \mathrm{E}+01$ & $3.44 \mathrm{E}+01$ & $3.12 \mathrm{E}+01$ & $3.84 \mathrm{E}-02$ & $2.87 \mathrm{E}-02$ & $2.56 \mathrm{E}-02$ & $2.45 \mathrm{E}-02$ \\
\hline 104 & $3.37 \mathrm{E}+01$ & $3.52 \mathrm{E}+01$ & $3.70 \mathrm{E}+01$ & $3.50 \mathrm{E}+01$ & $7.10 \mathrm{E}-02$ & $5.83 \mathrm{E}-02$ & $4.76 \mathrm{E}-02$ & $6.92 \mathrm{E}-02$ \\
\hline 105 & $2.39 \mathrm{E}+00$ & $2.98 \mathrm{E}+00$ & $1.98 \mathrm{E}+00$ & $3.18 \mathrm{E}+00$ & $4.04 \mathrm{E}-01$ & $3.85 \mathrm{E}-01$ & $3.97 \mathrm{E}-01$ & $4.37 \mathrm{E}-01$ \\
\hline 106 & $4.88 \mathrm{E}+00$ & $5.87 \mathrm{E}+00$ & $4.29 \mathrm{E}+00$ & $6.09 \mathrm{E}+00$ & $5.32 \mathrm{E}-01$ & $4.80 \mathrm{E}-01$ & $5.14 \mathrm{E}-01$ & $5.48 \mathrm{E}-01$ \\
\hline 107 & $1.16 \mathrm{E}+01$ & $1.56 \mathrm{E}+01$ & $1.10 \mathrm{E}+01$ & $9.69 \mathrm{E}+00$ & $1.62 \mathrm{E}-01$ & $1.53 \mathrm{E}-01$ & $1.39 \mathrm{E}-01$ & $1.78 \mathrm{E}-01$ \\
\hline 108 & $1.54 \mathrm{E}+00$ & $1.55 \mathrm{E}+00$ & $1.56 \mathrm{E}+00$ & $1.56 \mathrm{E}+00$ & $1.04 \mathrm{E}-01$ & $1.05 \mathrm{E}-01$ & $1.00 \mathrm{E}-01$ & $1.15 \mathrm{E}-01$ \\
\hline 133 & $2.61 \mathrm{E}+01$ & $2.63 \mathrm{E}+01$ & $2.64 \mathrm{E}+01$ & $2.65 \mathrm{E}+01$ & $3.75 \mathrm{E}-01$ & $3.61 \mathrm{E}-01$ & $3.41 \mathrm{E}-01$ & $3.72 \mathrm{E}-01$ \\
\hline 137 & $2.17 \mathrm{E}+01$ & $2.03 \mathrm{E}+01$ & $2.18 \mathrm{E}+01$ & $1.96 \mathrm{E}+01$ & $1.06 \mathrm{E}-01$ & $1.04 \mathrm{E}-01$ & $9.84 \mathrm{E}-02$ & $1.08 \mathrm{E}-01$ \\
\hline 138 & $1.30 \mathrm{E}+02$ & $1.22 \mathrm{E}+02$ & $1.27 \mathrm{E}+02$ & $1.25 \mathrm{E}+02$ & $3.72 \mathrm{E}-02$ & $4.85 \mathrm{E}-02$ & $3.32 \mathrm{E}-02$ & $9.69 \mathrm{E}-02$ \\
\hline 182 & $1.54 \mathrm{E}+00$ & $1.55 \mathrm{E}+00$ & $1.56 \mathrm{E}+00$ & $1.56 \mathrm{E}+00$ & $4.59 \mathrm{E}-02$ & $6.23 \mathrm{E}-02$ & $6.68 \mathrm{E}-02$ & $4.79 \mathrm{E}-02$ \\
\hline 183 & $3.08 \mathrm{E}+00$ & $3.09 \mathrm{E}+00$ & $3.11 \mathrm{E}+00$ & $3.12 \mathrm{E}+00$ & $2.27 \mathrm{E}-02$ & $3.47 \mathrm{E}-02$ & $3.86 \mathrm{E}-02$ & $4.24 \mathrm{E}-02$ \\
\hline 184 & $2.31 \mathrm{E}+00$ & $2.32 \mathrm{E}+00$ & $2.33 \mathrm{E}+00$ & $2.34 \mathrm{E}+00$ & $6.90 \mathrm{E}-02$ & $5.23 \mathrm{E}-02$ & $7.56 \mathrm{E}-02$ & $5.34 \mathrm{E}-02$ \\
\hline 196 & $2.74 \mathrm{E}+00$ & $2.32 \mathrm{E}+00$ & $2.82 \mathrm{E}+00$ & $3.18 \mathrm{E}+00$ & $6.24 \mathrm{E}-02$ & $8.67 \mathrm{E}-02$ & $6.05 \mathrm{E}-02$ & $6.52 \mathrm{E}-02$ \\
\hline 198 & $1.53 \mathrm{E}+02$ & $1.47 \mathrm{E}+02$ & $1.57 \mathrm{E}+02$ & $1.57 \mathrm{E}+02$ & $2.60 \mathrm{E}+00$ & $2.73 \mathrm{E}+00$ & $2.72 \mathrm{E}+00$ & $3.10 \mathrm{E}+00$ \\
\hline 204 & $7.77 \mathrm{E}+01$ & $7.75 \mathrm{E}+01$ & $8.18 \mathrm{E}+01$ & $7.95 \mathrm{E}+01$ & $1.38 \mathrm{E}+00$ & $1.44 \mathrm{E}+00$ & $1.42 \mathrm{E}+00$ & $1.54 \mathrm{E}+00$ \\
\hline 237 & $1.22 \mathrm{E}+01$ & $1.11 \mathrm{E}+01$ & $1.10 \mathrm{E}+01$ & $1.14 \mathrm{E}+01$ & $1.05 \mathrm{E}-01$ & 7.55E-02 & $1.03 \mathrm{E}-01$ & $1.10 \mathrm{E}-01$ \\
\hline 238 & $8.81 \mathrm{E}+03$ & $8.35 \mathrm{E}+03$ & $8.57 \mathrm{E}+03$ & $7.98 \mathrm{E}+03$ & $6.28 \mathrm{E}-01$ & $5.30 \mathrm{E}-01$ & $5.93 \mathrm{E}-01$ & $6.21 \mathrm{E}-01$ \\
\hline 239 & $5.51 \mathrm{E}+01$ & $5.41 \mathrm{E}+01$ & $6.16 \mathrm{E}+01$ & $5.64 \mathrm{E}+01$ & $3.14 \mathrm{E}-02$ & $3.14 \mathrm{E}-02$ & $3.14 \mathrm{E}-02$ & $3.14 \mathrm{E}-02$ \\
\hline
\end{tabular}


SRNL-STI-2011-00622

Revision 0

Table D - 10. SRAT Product ICP-MS

\begin{tabular}{|c|c|c|c|c|c|c|c|c|}
\hline \multirow[b]{2}{*}{$\begin{array}{c}3002 \\
\mathrm{~m} / \mathrm{z}\end{array}$} & \multicolumn{5}{|c|}{ Aqua regia ICP-MS Slurry, mg/kg } & \multicolumn{3}{|c|}{ Supernate, mg/L } \\
\hline & $\begin{array}{c}1 \\
92314 \\
\mu \mathrm{g} / \mathrm{g}\end{array}$ & $\begin{array}{c}2 \\
92315 \\
\mu \mathrm{g} / \mathrm{g}\end{array}$ & $\begin{array}{c}3 \\
92316 \\
\mu \mathrm{g} / \mathrm{g}\end{array}$ & $\begin{array}{c}4 \\
92317 \\
\mu \mathrm{g} / \mathrm{g}\end{array}$ & $\begin{array}{c}1 \\
92446 \\
\mathrm{mg} / \mathrm{L}\end{array}$ & $\begin{array}{c}2 \\
92447 \\
\mathrm{mg} / \mathrm{L}\end{array}$ & $\begin{array}{c}3 \\
92448 \\
\mathrm{mg} / \mathrm{L}\end{array}$ & $\begin{array}{c}4 \\
92449 \\
\mathrm{mg} / \mathrm{L}\end{array}$ \\
\hline 59 & $1.98 \mathrm{E}+01$ & $1.99 \mathrm{E}+01$ & $1.82 \mathrm{E}+01$ & $2.88 \mathrm{E}+01$ & $2.68 \mathrm{E}+00$ & $2.32 \mathrm{E}+00$ & $2.66 \mathrm{E}+00$ & $2.44 \mathrm{E}+00$ \\
\hline 88 & $4.83 \mathrm{E}+01$ & $4.82 \mathrm{E}+01$ & $5.04 \mathrm{E}+01$ & $5.44 \mathrm{E}+01$ & $3.73 \mathrm{E}+01$ & $3.53 \mathrm{E}+01$ & $3.66 \mathrm{E}+01$ & $3.60 \mathrm{E}+01$ \\
\hline 89 & $5.37 \mathrm{E}+01$ & $5.36 \mathrm{E}+01$ & $5.18 \mathrm{E}+01$ & $5.74 \mathrm{E}+01$ & $1.63 \mathrm{E}+01$ & $1.75 \mathrm{E}+01$ & $1.57 \mathrm{E}+01$ & $1.52 \mathrm{E}+01$ \\
\hline 90 & $4.87 \mathrm{E}+01$ & $3.66 \mathrm{E}+01$ & $5.65 \mathrm{E}+01$ & $5.31 \mathrm{E}+01$ & $3.34 \mathrm{E}+01$ & $3.53 \mathrm{E}+01$ & $3.40 \mathrm{E}+01$ & $3.46 \mathrm{E}+01$ \\
\hline 91 & $2.71 \mathrm{E}+01$ & $1.71 \mathrm{E}+01$ & $4.42 \mathrm{E}+01$ & $3.56 \mathrm{E}+01$ & $6.89 \mathrm{E}+00$ & $6.87 \mathrm{E}+00$ & $6.01 \mathrm{E}+00$ & $7.47 \mathrm{E}+00$ \\
\hline 92 & $3.25 \mathrm{E}+01$ & $2.46 \mathrm{E}+01$ & $5.35 \mathrm{E}+01$ & $4.32 \mathrm{E}+01$ & $6.60 \mathrm{E}+00$ & $7.17 \mathrm{E}+00$ & $7.37 \mathrm{E}+00$ & $6.92 \mathrm{E}+00$ \\
\hline 93 & $3.57 \mathrm{E}+01$ & $2.70 \mathrm{E}+01$ & $6.42 \mathrm{E}+01$ & $4.68 \mathrm{E}+01$ & $8.05 \mathrm{E}+00$ & $8.11 \mathrm{E}+00$ & $6.29 \mathrm{E}+00$ & $7.69 \mathrm{E}+00$ \\
\hline 94 & $3.13 \mathrm{E}+01$ & $2.25 \mathrm{E}+01$ & $5.23 \mathrm{E}+01$ & $5.29 \mathrm{E}+01$ & $7.60 \mathrm{E}+00$ & $7.52 \mathrm{E}+00$ & $6.98 \mathrm{E}+00$ & $8.24 \mathrm{E}+00$ \\
\hline 96 & $3.46 \mathrm{E}+01$ & $3.00 \mathrm{E}+01$ & $6.38 \mathrm{E}+01$ & $6.41 \mathrm{E}+01$ & $7.52 \mathrm{E}+00$ & $8.06 \mathrm{E}+00$ & $8.84 \mathrm{E}+00$ & $8.02 \mathrm{E}+00$ \\
\hline 101 & $7.28 \mathrm{E}+01$ & $7.31 \mathrm{E}+01$ & $6.95 \mathrm{E}+01$ & $7.07 \mathrm{E}+01$ & $2.26 \mathrm{E}+01$ & $2.37 \mathrm{E}+01$ & $2.27 \mathrm{E}+01$ & $2.40 \mathrm{E}+01$ \\
\hline 102 & $6.99 \mathrm{E}+01$ & $6.93 \mathrm{E}+01$ & $6.73 \mathrm{E}+01$ & $7.20 \mathrm{E}+01$ & $2.27 \mathrm{E}+01$ & $2.25 \mathrm{E}+01$ & $2.14 \mathrm{E}+01$ & $2.15 \mathrm{E}+01$ \\
\hline 103 & $3.37 \mathrm{E}+01$ & $3.69 \mathrm{E}+01$ & $2.94 \mathrm{E}+01$ & $3.70 \mathrm{E}+01$ & $5.45 \mathrm{E}+00$ & $5.69 \mathrm{E}+00$ & $5.32 \mathrm{E}+00$ & $4.99 \mathrm{E}+00$ \\
\hline 104 & $3.50 \mathrm{E}+01$ & $3.99 \mathrm{E}+01$ & $3.62 \mathrm{E}+01$ & $4.12 \mathrm{E}+01$ & $1.21 \mathrm{E}+01$ & $1.19 \mathrm{E}+01$ & $1.22 \mathrm{E}+01$ & $1.27 \mathrm{E}+01$ \\
\hline 110 & $8.13 \mathrm{E}+00$ & $1.01 \mathrm{E}+01$ & $1.38 \mathrm{E}+01$ & $9.55 \mathrm{E}+00$ & $2.93 \mathrm{E}+00$ & $2.55 \mathrm{E}+00$ & $3.16 \mathrm{E}+00$ & $2.68 \mathrm{E}+00$ \\
\hline 111 & $1.06 \mathrm{E}+01$ & $1.05 \mathrm{E}+01$ & $1.15 \mathrm{E}+01$ & $1.39 \mathrm{E}+01$ & $3.41 \mathrm{E}+00$ & $4.24 \mathrm{E}+00$ & $3.99 \mathrm{E}+00$ & $2.84 \mathrm{E}+00$ \\
\hline 112 & $1.70 \mathrm{E}+01$ & $1.76 \mathrm{E}+01$ & $1.70 \mathrm{E}+01$ & $1.72 \mathrm{E}+01$ & $4.22 \mathrm{E}+00$ & $5.75 \mathrm{E}+00$ & $5.21 \mathrm{E}+00$ & $5.60 \mathrm{E}+00$ \\
\hline 114 & $2.14 \mathrm{E}+01$ & $2.26 \mathrm{E}+01$ & $2.15 \mathrm{E}+01$ & $2.27 \mathrm{E}+01$ & $6.39 \mathrm{E}+00$ & $8.30 \mathrm{E}+00$ & $6.68 \mathrm{E}+00$ & $6.13 \mathrm{E}+00$ \\
\hline 116 & $8.33 \mathrm{E}+00$ & $8.40 \mathrm{E}+00$ & $7.91 \mathrm{E}+00$ & $6.42 \mathrm{E}+00$ & $<2.69 \mathrm{E}+00$ & $<2.73 \mathrm{E}+00$ & $<2.74 \mathrm{E}+00$ & $<2.74 \mathrm{E}+00$ \\
\hline 119 & $8.98 \mathrm{E}+01$ & $8.78 \mathrm{E}+01$ & $8.78 \mathrm{E}+01$ & $9.54 \mathrm{E}+01$ & $<3.40 \mathrm{E}+01$ & $<3.64 \mathrm{E}+01$ & $<3.68 \mathrm{E}+01$ & $<3.61 \mathrm{E}+01$ \\
\hline 125 & $3.41 \mathrm{E}+01$ & $3.39 \mathrm{E}+01$ & $3.39 \mathrm{E}+01$ & $3.45 \mathrm{E}+01$ & $<8.62 \mathrm{E}+00$ & $<8.74 \mathrm{E}+00$ & $<8.77 \mathrm{E}+00$ & $<8.76 \mathrm{E}+00$ \\
\hline 133 & $1.22 \mathrm{E}+01$ & $1.21 \mathrm{E}+01$ & $1.21 \mathrm{E}+01$ & $1.23 \mathrm{E}+01$ & $<2.02 \mathrm{E}+00$ & $<2.99 \mathrm{E}+00$ & $<2.18 \mathrm{E}+00$ & $<1.64 \mathrm{E}+00$ \\
\hline 138 & $1.36 \mathrm{E}+02$ & $1.33 \mathrm{E}+02$ & $1.36 \mathrm{E}+02$ & $1.37 \mathrm{E}+02$ & $7.54 \mathrm{E}+00$ & $1.20 \mathrm{E}+01$ & $5.43 \mathrm{E}+00$ & $1.19 \mathrm{E}+01$ \\
\hline 139 & $1.36 \mathrm{E}+02$ & $1.31 \mathrm{E}+02$ & $1.30 \mathrm{E}+02$ & $1.39 \mathrm{E}+02$ & $2.56 \mathrm{E}+01$ & $2.58 \mathrm{E}+01$ & $2.56 \mathrm{E}+01$ & $2.35 \mathrm{E}+01$ \\
\hline 140 & $1.28 \mathrm{E}+02$ & $1.37 \mathrm{E}+02$ & $1.31 \mathrm{E}+02$ & $1.32 \mathrm{E}+02$ & $6.86 \mathrm{E}+00$ & $4.81 \mathrm{E}+00$ & $4.76 \mathrm{E}+00$ & $4.16 \mathrm{E}+00$ \\
\hline 141 & $1.25 \mathrm{E}+02$ & $1.14 \mathrm{E}+02$ & $1.22 \mathrm{E}+02$ & $1.20 \mathrm{E}+02$ & $2.36 \mathrm{E}+01$ & $2.28 \mathrm{E}+01$ & $2.33 \mathrm{E}+01$ & $2.22 \mathrm{E}+01$ \\
\hline 142 & $1.28 \mathrm{E}+02$ & $1.22 \mathrm{E}+02$ & $1.27 \mathrm{E}+02$ & $1.31 \mathrm{E}+02$ & $3.61 \mathrm{E}+00$ & $3.72 \mathrm{E}+00$ & $3.62 \mathrm{E}+00$ & $3.08 \mathrm{E}+00$ \\
\hline 143 & $1.12 \mathrm{E}+02$ & $1.12 \mathrm{E}+02$ & $1.14 \mathrm{E}+02$ & $1.16 \mathrm{E}+02$ & $2.70 \mathrm{E}+01$ & $2.51 \mathrm{E}+01$ & $2.53 \mathrm{E}+01$ & $2.73 \mathrm{E}+01$ \\
\hline 144 & $1.25 \mathrm{E}+02$ & $1.30 \mathrm{E}+02$ & $1.24 \mathrm{E}+02$ & $1.36 \mathrm{E}+02$ & $2.46 \mathrm{E}+01$ & $2.51 \mathrm{E}+01$ & $2.62 \mathrm{E}+01$ & $2.50 \mathrm{E}+01$ \\
\hline 145 & $8.19 \mathrm{E}+01$ & $8.31 \mathrm{E}+01$ & $8.16 \mathrm{E}+01$ & $8.72 \mathrm{E}+01$ & $1.80 \mathrm{E}+01$ & $1.85 \mathrm{E}+01$ & $1.88 \mathrm{E}+01$ & $1.91 \mathrm{E}+01$ \\
\hline
\end{tabular}


SRNL-STI-2011-00622

Revision 0

\begin{tabular}{|c|c|c|c|c|c|c|c|c|}
\hline \multirow{4}{*}{$\begin{array}{c}3002 \\
\mathrm{~m} / \mathrm{z}\end{array}$} & \multicolumn{4}{|c|}{ Aqua regia ICP-MS Slurry, mg/kg } & \multicolumn{4}{|c|}{ Supernate, mg/L } \\
\hline & 1 & 2 & 3 & 4 & 1 & 2 & 3 & 4 \\
\hline & 92314 & 92315 & 92316 & 92317 & 92446 & 92447 & 92448 & 92449 \\
\hline & $\mu \mathrm{g} / \mathrm{g}$ & $\mu \mathrm{g} / \mathrm{g}$ & $\mu \mathrm{g} / \mathrm{g}$ & $\mu \mathrm{g} / \mathrm{g}$ & $\mathrm{mg} / \mathrm{L}$ & $\mathrm{mg} / \mathrm{L}$ & $\mathrm{mg} / \mathrm{L}$ & $\mathrm{mg} / \mathrm{L}$ \\
\hline 146 & $6.73 \mathrm{E}+01$ & $6.69 \mathrm{E}+01$ & $6.50 \mathrm{E}+01$ & $7.04 \mathrm{E}+01$ & $1.58 \mathrm{E}+01$ & $1.47 \mathrm{E}+01$ & $1.47 \mathrm{E}+01$ & $1.49 \mathrm{E}+01$ \\
\hline 147 & $4.02 \mathrm{E}+01$ & $4.38 \mathrm{E}+01$ & $4.31 \mathrm{E}+01$ & $4.23 \mathrm{E}+01$ & $9.08 \mathrm{E}+00$ & $1.01 \mathrm{E}+01$ & $8.46 \mathrm{E}+00$ & $1.06 \mathrm{E}+01$ \\
\hline 148 & $4.14 \mathrm{E}+01$ & $4.26 \mathrm{E}+01$ & $4.02 \mathrm{E}+01$ & $4.95 \mathrm{E}+01$ & $9.50 \mathrm{E}+00$ & $1.04 \mathrm{E}+01$ & $8.42 \mathrm{E}+00$ & $9.90 \mathrm{E}+00$ \\
\hline 150 & $3.56 \mathrm{E}+01$ & $3.82 \mathrm{E}+01$ & $3.98 \mathrm{E}+01$ & $4.44 \mathrm{E}+01$ & $8.85 \mathrm{E}+00$ & $8.57 \mathrm{E}+00$ & $8.54 \mathrm{E}+00$ & $8.62 \mathrm{E}+00$ \\
\hline 152 & $1.22 \mathrm{E}+01$ & $1.42 \mathrm{E}+01$ & $1.35 \mathrm{E}+01$ & $1.08 \mathrm{E}+01$ & $3.23 \mathrm{E}+00$ & $3.12 \mathrm{E}+00$ & $2.93 \mathrm{E}+00$ & $2.47 \mathrm{E}+00$ \\
\hline 153 & $7.30 \mathrm{E}+00$ & $7.27 \mathrm{E}+00$ & $7.27 \mathrm{E}+00$ & $7.39 \mathrm{E}+00$ & $1.36 \mathrm{E}+00$ & $1.75 \mathrm{E}+00$ & $1.26 \mathrm{E}+00$ & $1.13 \mathrm{E}+00$ \\
\hline 154 & $6.01 \mathrm{E}+00$ & $5.41 \mathrm{E}+00$ & $6.51 \mathrm{E}+00$ & $7.25 \mathrm{E}+00$ & $2.17 \mathrm{E}+00$ & $2.28 \mathrm{E}+00$ & $1.98 \mathrm{E}+00$ & $2.35 \mathrm{E}+00$ \\
\hline 155 & $2.24 \mathrm{E}+01$ & $2.21 \mathrm{E}+01$ & $2.36 \mathrm{E}+01$ & $2.31 \mathrm{E}+01$ & $1.04 \mathrm{E}+01$ & $7.83 \mathrm{E}+00$ & $8.05 \mathrm{E}+00$ & $8.03 \mathrm{E}+00$ \\
\hline 156 & $3.23 \mathrm{E}+01$ & $3.00 \mathrm{E}+01$ & $3.20 \mathrm{E}+01$ & $3.17 \mathrm{E}+01$ & $1.33 \mathrm{E}+01$ & $1.31 \mathrm{E}+01$ & $1.18 \mathrm{E}+01$ & $1.24 \mathrm{E}+01$ \\
\hline 157 & $2.24 \mathrm{E}+01$ & $2.10 \mathrm{E}+01$ & $2.26 \mathrm{E}+01$ & $2.92 \mathrm{E}+01$ & $9.22 \mathrm{E}+00$ & $9.52 \mathrm{E}+00$ & $8.92 \mathrm{E}+00$ & $9.61 \mathrm{E}+00$ \\
\hline 158 & $3.28 \mathrm{E}+01$ & $3.55 \mathrm{E}+01$ & $3.73 \mathrm{E}+01$ & $3.59 \mathrm{E}+01$ & $1.54 \mathrm{E}+01$ & $1.63 \mathrm{E}+01$ & $1.52 \mathrm{E}+01$ & $1.46 \mathrm{E}+01$ \\
\hline 160 & $3.41 \mathrm{E}+01$ & $3.46 \mathrm{E}+01$ & $3.08 \mathrm{E}+01$ & $3.79 \mathrm{E}+01$ & $1.27 \mathrm{E}+01$ & $1.21 \mathrm{E}+01$ & $1.18 \mathrm{E}+01$ & $1.26 \mathrm{E}+01$ \\
\hline 235 & $6.38 \mathrm{E}+01$ & $6.44 \mathrm{E}+01$ & $6.27 \mathrm{E}+01$ & $6.52 \mathrm{E}+01$ & $2.54 \mathrm{E}+01$ & $2.19 \mathrm{E}+01$ & $2.18 \mathrm{E}+01$ & $2.18 \mathrm{E}+01$ \\
\hline 236 & $<4.94 \mathrm{E}+00$ & $<6.13 \mathrm{E}+00$ & $<6.75 \mathrm{E}+00$ & $<5.48 \mathrm{E}+00$ & $<4.31 \mathrm{E}+00$ & $<4.37 \mathrm{E}+00$ & $<4.39 \mathrm{E}+00$ & $<4.38 \mathrm{E}+00$ \\
\hline 237 & $1.36 \mathrm{E}+01$ & $2.16 \mathrm{E}+01$ & $1.77 \mathrm{E}+01$ & $1.37 \mathrm{E}+01$ & $9.22 \mathrm{E}+00$ & $7.64 \mathrm{E}+00$ & $8.00 \mathrm{E}+00$ & $9.97 \mathrm{E}+00$ \\
\hline 238 & $8.87 \mathrm{E}+03$ & $8.63 \mathrm{E}+03$ & $8.68 \mathrm{E}+03$ & $9.24 \mathrm{E}+03$ & $3.47 \mathrm{E}+03$ & $3.39 \mathrm{E}+03$ & $3.41 \mathrm{E}+03$ & $3.52 \mathrm{E}+03$ \\
\hline 239 & $6.38 \mathrm{E}+01$ & $6.41 \mathrm{E}+01$ & $5.74 \mathrm{E}+01$ & $5.82 \mathrm{E}+01$ & $5.60 \mathrm{E}+00$ & $5.65 \mathrm{E}+00$ & $5.70 \mathrm{E}+00$ & $6.93 \mathrm{E}+00$ \\
\hline
\end{tabular}


SRNL-STI-2011-00622

Revision 0

Table D - 11. SRAT Product pH 3 ICP-MS

\begin{tabular}{|c|c|c|c|c|c|c|c|c|}
\hline \multirow{4}{*}{$\begin{array}{c}3002 \\
\mathrm{~m} / \mathrm{z}\end{array}$} & \multicolumn{4}{|c|}{ Aqua regia ICP-MS, mg/kg Slurry Basis } & \multicolumn{4}{|c|}{ Supernate Basis, mg/L } \\
\hline & 1 & 2 & 3 & 4 & 1 & 2 & 3 & \\
\hline & 92366 & 92367 & 92368 & 92369 & 92468 & 92469 & 92470 & 92471 \\
\hline & $\mu \mathrm{g} / \mathrm{g}$ & $\mu \mathrm{g} / \mathrm{g}$ & $\mu \mathrm{g} / \mathrm{g}$ & $\mu \mathrm{g} / \mathrm{g}$ & $\mathrm{mg} / \mathrm{L}$ & $\mathrm{mg} / \mathrm{L}$ & $\mathrm{mg} / \mathrm{L}$ & $\mathrm{mg} / \mathrm{L}$ \\
\hline 59 & $<1.74 \mathrm{E}+01$ & $<1.72 \mathrm{E}+01$ & $<2.07 \mathrm{E}+01$ & $<1.90 \mathrm{E}+01$ & $<6.38 \mathrm{E}+00$ & $<6.41 \mathrm{E}+00$ & $<6.48 \mathrm{E}+00$ & $<6.62 \mathrm{E}+00$ \\
\hline 88 & $4.62 \mathrm{E}+01$ & $5.04 \mathrm{E}+01$ & $5.04 \mathrm{E}+01$ & $5.36 \mathrm{E}+01$ & $4.22 \mathrm{E}+01$ & $4.08 \mathrm{E}+01$ & $4.60 \mathrm{E}+01$ & $4.63 \mathrm{E}+01$ \\
\hline 89 & $5.13 \mathrm{E}+01$ & $5.17 \mathrm{E}+01$ & $4.96 \mathrm{E}+01$ & $5.11 \mathrm{E}+01$ & $3.14 \mathrm{E}+01$ & $3.54 \mathrm{E}+01$ & $2.89 \mathrm{E}+01$ & $3.10 \mathrm{E}+01$ \\
\hline 90 & $4.92 \mathrm{E}+01$ & $4.03 \mathrm{E}+01$ & $5.00 \mathrm{E}+01$ & $4.97 \mathrm{E}+01$ & $3.85 \mathrm{E}+01$ & $4.78 \mathrm{E}+01$ & $4.73 \mathrm{E}+01$ & $4.66 \mathrm{E}+01$ \\
\hline 91 & $<3.54 \mathrm{E}+01$ & $<2.17 \mathrm{E}+01$ & $<3.99 \mathrm{E}+01$ & $<3.55 \mathrm{E}+01$ & $<1.06 \mathrm{E}+01$ & $<1.07 \mathrm{E}+01$ & $<1.08 \mathrm{E}+01$ & $<1.10 \mathrm{E}+01$ \\
\hline 92 & $3.87 \mathrm{E}+01$ & $<2.32 \mathrm{E}+01$ & $3.99 \mathrm{E}+01$ & $4.28 \mathrm{E}+01$ & $1.19 \mathrm{E}+01$ & $6.94 \mathrm{E}+00$ & $<6.48 \mathrm{E}+00$ & $6.67 \mathrm{E}+00$ \\
\hline 93 & $4.13 \mathrm{E}+01$ & $3.10 \mathrm{E}+01$ & $4.86 \mathrm{E}+01$ & $4.46 \mathrm{E}+01$ & $9.47 \mathrm{E}+00$ & $1.02 \mathrm{E}+01$ & $8.55 \mathrm{E}+00$ & $1.13 \mathrm{E}+01$ \\
\hline 94 & $4.42 \mathrm{E}+01$ & $2.88 \mathrm{E}+01$ & $3.93 \mathrm{E}+01$ & $4.64 \mathrm{E}+01$ & $7.44 \mathrm{E}+00$ & $8.34 \mathrm{E}+00$ & $7.46 \mathrm{E}+00$ & $1.06 \mathrm{E}+01$ \\
\hline 96 & $4.25 \mathrm{E}+01$ & $2.63 \mathrm{E}+01$ & $4.90 \mathrm{E}+01$ & $4.16 \mathrm{E}+01$ & $8.78 \mathrm{E}+00$ & $7.56 \mathrm{E}+00$ & $6.91 \mathrm{E}+00$ & $1.10 \mathrm{E}+01$ \\
\hline 101 & $6.57 \mathrm{E}+01$ & $6.64 \mathrm{E}+01$ & $6.98 \mathrm{E}+01$ & $6.26 \mathrm{E}+01$ & $2.46 \mathrm{E}+01$ & $2.54 \mathrm{E}+01$ & $2.64 \mathrm{E}+01$ & $2.94 \mathrm{E}+01$ \\
\hline 102 & $6.24 \mathrm{E}+01$ & $6.33 \mathrm{E}+01$ & $6.23 \mathrm{E}+01$ & $5.71 \mathrm{E}+01$ & $2.41 \mathrm{E}+01$ & $2.33 \mathrm{E}+01$ & $2.47 \mathrm{E}+01$ & $2.69 \mathrm{E}+01$ \\
\hline 103 & $<3.33 \mathrm{E}+01$ & $<3.07 \mathrm{E}+01$ & $3.32 \mathrm{E}+01$ & $<3.31 \mathrm{E}+01$ & $<8.51 \mathrm{E}+00$ & $<8.54 \mathrm{E}+00$ & $9.90 \mathrm{E}+00$ & $<8.83 \mathrm{E}+00$ \\
\hline 104 & $3.47 \mathrm{E}+01$ & $3.35 \mathrm{E}+01$ & $3.46 \mathrm{E}+01$ & $3.61 \mathrm{E}+01$ & $1.71 \mathrm{E}+01$ & $1.52 \mathrm{E}+01$ & $1.43 \mathrm{E}+01$ & $1.54 \mathrm{E}+01$ \\
\hline 110 & $8.00 \mathrm{E}+00$ & $7.49 \mathrm{E}+00$ & $9.64 \mathrm{E}+00$ & $8.88 \mathrm{E}+00$ & $5.13 \mathrm{E}+00$ & $5.03 \mathrm{E}+00$ & $5.53 \mathrm{E}+00$ & $4.88 \mathrm{E}+00$ \\
\hline 111 & $<1.06 \mathrm{E}+01$ & $<9.19 \mathrm{E}+00$ & $<8.19 \mathrm{E}+00$ & $<1.05 \mathrm{E}+01$ & $<1.49 \mathrm{E}+01$ & $<1.49 \mathrm{E}+01$ & $<1.51 \mathrm{E}+01$ & $<1.54 \mathrm{E}+01$ \\
\hline 112 & $1.74 \mathrm{E}+01$ & $1.54 \mathrm{E}+01$ & $1.65 \mathrm{E}+01$ & $1.88 \mathrm{E}+01$ & $7.32 \mathrm{E}+00$ & $1.13 \mathrm{E}+01$ & $7.70 \mathrm{E}+00$ & $1.01 \mathrm{E}+01$ \\
\hline 114 & $2.17 \mathrm{E}+01$ & $1.89 \mathrm{E}+01$ & $2.06 \mathrm{E}+01$ & $2.14 \mathrm{E}+01$ & $1.12 \mathrm{E}+01$ & $1.73 \mathrm{E}+01$ & $1.66 \mathrm{E}+01$ & $1.18 \mathrm{E}+01$ \\
\hline 116 & $<7.76 \mathrm{E}+00$ & $8.40 \mathrm{E}+00$ & $<6.83 \mathrm{E}+00$ & $<6.31 \mathrm{E}+00$ & $<4.25 \mathrm{E}+00$ & $4.93 \mathrm{E}+00$ & $<4.32 \mathrm{E}+00$ & $<4.41 \mathrm{E}+00$ \\
\hline 119 & $9.76 \mathrm{E}+01$ & $9.74 \mathrm{E}+01$ & $1.03 \mathrm{E}+02$ & $1.04 \mathrm{E}+02$ & $8.97 \mathrm{E}+01$ & $9.76 \mathrm{E}+01$ & $9.06 \mathrm{E}+01$ & $1.00 \mathrm{E}+02$ \\
\hline 125 & $<1.10 \mathrm{E}+01$ & $<1.13 \mathrm{E}+01$ & $<1.10 \mathrm{E}+01$ & $<1.10 \mathrm{E}+01$ & $<1.91 \mathrm{E}+01$ & $<1.92 \mathrm{E}+01$ & $<1.94 \mathrm{E}+01$ & $<1.99 \mathrm{E}+01$ \\
\hline 133 & $<1.10 \mathrm{E}+01$ & $1.13 \mathrm{E}+01$ & $<1.10 \mathrm{E}+01$ & $<1.10 \mathrm{E}+01$ & $<8.51 \mathrm{E}+00$ & $8.65 \mathrm{E}+00$ & $<8.63 \mathrm{E}+00$ & $<8.83 \mathrm{E}+00$ \\
\hline 138 & $1.30 \mathrm{E}+02$ & $1.29 \mathrm{E}+02$ & $<1.24 \mathrm{E}+02$ & $<1.30 \mathrm{E}+02$ & $1.11 \mathrm{E}+01$ & $1.29 \mathrm{E}+01$ & $<1.08 \mathrm{E}+01$ & $<1.10 \mathrm{E}+01$ \\
\hline 139 & $1.20 \mathrm{E}+02$ & $1.27 \mathrm{E}+02$ & $1.27 \mathrm{E}+02$ & $1.22 \mathrm{E}+02$ & $4.91 \mathrm{E}+01$ & $4.85 \mathrm{E}+01$ & $4.92 \mathrm{E}+01$ & $4.96 \mathrm{E}+01$ \\
\hline 140 & $<1.24 \mathrm{E}+02$ & $<1.25 \mathrm{E}+02$ & $<1.24 \mathrm{E}+02$ & $<1.22 \mathrm{E}+02$ & $<1.06 \mathrm{E}+01$ & $<1.07 \mathrm{E}+01$ & $<1.08 \mathrm{E}+01$ & $<1.10 \mathrm{E}+01$ \\
\hline 141 & $1.08 \mathrm{E}+02$ & $1.06 \mathrm{E}+02$ & $1.11 \mathrm{E}+02$ & $1.08 \mathrm{E}+02$ & $4.48 \mathrm{E}+01$ & $4.26 \mathrm{E}+01$ & $4.72 \mathrm{E}+01$ & $5.43 \mathrm{E}+01$ \\
\hline 142 & $1.13 \mathrm{E}+02$ & $1.09 \mathrm{E}+02$ & $1.13 \mathrm{E}+02$ & $1.12 \mathrm{E}+02$ & $6.87 \mathrm{E}+00$ & $8.87 \mathrm{E}+00$ & $5.91 \mathrm{E}+00$ & $6.57 \mathrm{E}+00$ \\
\hline 143 & $1.04 \mathrm{E}+02$ & $1.08 \mathrm{E}+02$ & $1.11 \mathrm{E}+02$ & $1.05 \mathrm{E}+02$ & $4.78 \mathrm{E}+01$ & $5.79 \mathrm{E}+01$ & $4.71 \mathrm{E}+01$ & $4.87 \mathrm{E}+01$ \\
\hline 144 & $1.17 \mathrm{E}+02$ & $1.12 \mathrm{E}+02$ & $1.14 \mathrm{E}+02$ & $1.15 \mathrm{E}+02$ & $4.42 \mathrm{E}+01$ & $4.18 \mathrm{E}+01$ & $4.24 \mathrm{E}+01$ & $4.52 \mathrm{E}+01$ \\
\hline 145 & $7.22 \mathrm{E}+01$ & $7.74 \mathrm{E}+01$ & $7.31 \mathrm{E}+01$ & $7.42 \mathrm{E}+01$ & $3.25 \mathrm{E}+01$ & $3.55 \mathrm{E}+01$ & $3.32 \mathrm{E}+01$ & $4.09 \mathrm{E}+01$ \\
\hline
\end{tabular}


SRNL-STI-2011-00622

Revision 0

\begin{tabular}{|c|c|c|c|c|c|c|c|c|}
\hline \multirow{4}{*}{$\begin{array}{c}3002 \\
\mathrm{~m} / \mathrm{z}\end{array}$} & \multicolumn{4}{|c|}{ Aqua regia ICP-MS, mg/kg Slurry Basis } & \multicolumn{4}{|c|}{ Supernate Basis, mg/L } \\
\hline & 1 & 2 & 3 & 4 & 1 & 2 & 3 & \\
\hline & 92366 & 92367 & 92368 & 92369 & 92468 & 92469 & 92470 & 92471 \\
\hline & $\mu \mathrm{g} / \mathrm{g}$ & $\mu \mathrm{g} / \mathrm{g}$ & $\mu \mathrm{g} / \mathrm{g}$ & $\mu \mathrm{g} / \mathrm{g}$ & $\mathrm{mg} / \mathrm{L}$ & $\mathrm{mg} / \mathrm{L}$ & $\mathrm{mg} / \mathrm{L}$ & $\mathrm{mg} / \mathrm{L}$ \\
\hline 146 & $6.65 \mathrm{E}+01$ & $6.34 \mathrm{E}+01$ & $6.26 \mathrm{E}+01$ & $6.39 \mathrm{E}+01$ & $2.78 \mathrm{E}+01$ & $2.95 \mathrm{E}+01$ & $3.35 \mathrm{E}+01$ & $2.89 \mathrm{E}+01$ \\
\hline 147 & $4.10 \mathrm{E}+01$ & $3.74 \mathrm{E}+01$ & $3.91 \mathrm{E}+01$ & $4.14 \mathrm{E}+01$ & $1.74 \mathrm{E}+01$ & $1.63 \mathrm{E}+01$ & $1.77 \mathrm{E}+01$ & $2.33 \mathrm{E}+01$ \\
\hline 148 & $3.53 \mathrm{E}+01$ & $3.82 \mathrm{E}+01$ & $4.15 \mathrm{E}+01$ & $3.67 \mathrm{E}+01$ & $1.70 \mathrm{E}+01$ & $1.98 \mathrm{E}+01$ & $1.65 \mathrm{E}+01$ & $2.01 \mathrm{E}+01$ \\
\hline 150 & $3.60 \mathrm{E}+01$ & $3.39 \mathrm{E}+01$ & $3.72 \mathrm{E}+01$ & $3.63 \mathrm{E}+01$ & $1.60 \mathrm{E}+01$ & $1.62 \mathrm{E}+01$ & $1.58 \mathrm{E}+01$ & $1.56 \mathrm{E}+01$ \\
\hline 152 & $1.39 \mathrm{E}+01$ & $1.15 \mathrm{E}+01$ & $1.19 \mathrm{E}+01$ & $1.16 \mathrm{E}+01$ & $7.64 \mathrm{E}+00$ & $6.51 \mathrm{E}+00$ & $7.03 \mathrm{E}+00$ & $5.80 \mathrm{E}+00$ \\
\hline 153 & $<7.36 \mathrm{E}+00$ & $<7.50 \mathrm{E}+00$ & $<7.35 \mathrm{E}+00$ & $<7.35 \mathrm{E}+00$ & $<4.25 \mathrm{E}+00$ & $<4.27 \mathrm{E}+00$ & $<4.32 \mathrm{E}+00$ & $<4.41 \mathrm{E}+00$ \\
\hline 154 & $5.66 \mathrm{E}+00$ & $<5.95 \mathrm{E}+00$ & $<6.65 \mathrm{E}+00$ & $<6.48 \mathrm{E}+00$ & $4.32 \mathrm{E}+00$ & $<4.27 \mathrm{E}+00$ & $<4.32 \mathrm{E}+00$ & $<4.41 \mathrm{E}+00$ \\
\hline 155 & $2.11 \mathrm{E}+01$ & $2.01 \mathrm{E}+01$ & $2.02 \mathrm{E}+01$ & $2.26 \mathrm{E}+01$ & $1.70 \mathrm{E}+01$ & $1.76 \mathrm{E}+01$ & $1.64 \mathrm{E}+01$ & $1.61 \mathrm{E}+01$ \\
\hline 156 & $3.00 \mathrm{E}+01$ & $2.89 \mathrm{E}+01$ & $2.93 \mathrm{E}+01$ & $2.98 \mathrm{E}+01$ & $2.35 \mathrm{E}+01$ & $2.61 \mathrm{E}+01$ & $2.37 \mathrm{E}+01$ & $2.61 \mathrm{E}+01$ \\
\hline 157 & $2.08 \mathrm{E}+01$ & $1.99 \mathrm{E}+01$ & $1.91 \mathrm{E}+01$ & $2.07 \mathrm{E}+01$ & $1.85 \mathrm{E}+01$ & $2.05 \mathrm{E}+01$ & $2.21 \mathrm{E}+01$ & $2.32 \mathrm{E}+01$ \\
\hline 158 & $3.56 \mathrm{E}+01$ & $3.15 \mathrm{E}+01$ & $3.53 \mathrm{E}+01$ & $3.45 \mathrm{E}+01$ & $2.84 \mathrm{E}+01$ & $2.37 \mathrm{E}+01$ & $2.58 \mathrm{E}+01$ & $2.79 \mathrm{E}+01$ \\
\hline 160 & $3.16 \mathrm{E}+01$ & $3.00 \mathrm{E}+01$ & $3.19 \mathrm{E}+01$ & $3.02 \mathrm{E}+01$ & $2.49 \mathrm{E}+01$ & $2.68 \mathrm{E}+01$ & $2.77 \mathrm{E}+01$ & $2.66 \mathrm{E}+01$ \\
\hline 235 & $6.13 \mathrm{E}+01$ & $6.04 \mathrm{E}+01$ & $6.25 \mathrm{E}+01$ & $6.23 \mathrm{E}+01$ & $6.51 \mathrm{E}+01$ & $6.87 \mathrm{E}+01$ & $6.48 \mathrm{E}+01$ & $6.64 \mathrm{E}+01$ \\
\hline 236 & $4.50 \mathrm{E}+00$ & $<3.75 \mathrm{E}+00$ & $<5.70 \mathrm{E}+00$ & $<4.30 \mathrm{E}+00$ & $6.41 \mathrm{E}+00$ & $<4.27 \mathrm{E}+00$ & $<4.32 \mathrm{E}+00$ & $<4.41 \mathrm{E}+00$ \\
\hline 237 & $1.68 \mathrm{E}+01$ & $1.36 \mathrm{E}+01$ & $1.73 \mathrm{E}+01$ & $1.37 \mathrm{E}+01$ & $1.12 \mathrm{E}+01$ & $1.36 \mathrm{E}+01$ & $1.12 \mathrm{E}+01$ & $1.37 \mathrm{E}+01$ \\
\hline 238 & $8.97 \mathrm{E}+03$ & $8.60 \mathrm{E}+03$ & $8.86 \mathrm{E}+03$ & $8.58 \mathrm{E}+03$ & $9.38 \mathrm{E}+03$ & $8.82 \mathrm{E}+03$ & $9.21 \mathrm{E}+03$ & $9.39 \mathrm{E}+03$ \\
\hline 239 & $6.30 \mathrm{E}+01$ & $5.57 \mathrm{E}+01$ & $6.04 \mathrm{E}+01$ & $5.81 \mathrm{E}+01$ & $1.92 \mathrm{E}+01$ & $1.93 \mathrm{E}+01$ & $2.61 \mathrm{E}+01$ & $2.03 \mathrm{E}+01$ \\
\hline
\end{tabular}


SRNL-STI-2011-00622

Revision 0

Table D - 12. SRAT Product pH 2 ICP-MS

\begin{tabular}{|c|c|c|c|c|c|c|c|c|}
\hline \multirow[b]{2}{*}{$\begin{array}{c}3002 \\
\mathrm{~m} / \mathrm{z}\end{array}$} & \multicolumn{4}{|c|}{ Aqua regia ICP-MS Slurry, mg/kg Slurry Basis } & \multicolumn{4}{|c|}{ Supernate Basis, mg/L } \\
\hline & $\begin{array}{c}1 \\
92359 \\
\mu \mathrm{g} / \mathrm{g}\end{array}$ & $\begin{array}{c}2 \\
92360 \\
\mu \mathrm{g} / \mathrm{g}\end{array}$ & $\begin{array}{c}3 \\
92361 \\
\mu \mathrm{g} / \mathrm{g}\end{array}$ & $\begin{array}{c}4 \\
92362 \\
\mu \mathrm{g} / \mathrm{g}\end{array}$ & $\begin{array}{c}1 \\
92352 \\
\mathrm{mg} / \mathrm{L}\end{array}$ & $\begin{array}{c}2 \\
92353 \\
\mathrm{mg} / \mathrm{L}\end{array}$ & $\begin{array}{c}3 \\
92354 \\
\mathrm{mg} / \mathrm{L}\end{array}$ & $\begin{array}{c}4 \\
92355 \\
\mathrm{mg} / \mathrm{L}\end{array}$ \\
\hline 59 & $1.87 \mathrm{E}+01$ & $2.12 \mathrm{E}+01$ & $1.74 \mathrm{E}+01$ & $2.10 \mathrm{E}+01$ & $7.79 \mathrm{E}+00$ & $<6.66 \mathrm{E}+00$ & $1.41 \mathrm{E}+01$ & $<6.75 \mathrm{E}+00$ \\
\hline 88 & $4.89 \mathrm{E}+01$ & $4.86 \mathrm{E}+01$ & $4.91 \mathrm{E}+01$ & $4.75 \mathrm{E}+01$ & $5.01 \mathrm{E}+01$ & $4.86 \mathrm{E}+01$ & $4.39 \mathrm{E}+01$ & $4.37 \mathrm{E}+01$ \\
\hline 89 & $5.18 \mathrm{E}+01$ & $5.38 \mathrm{E}+01$ & $5.05 \mathrm{E}+01$ & $5.25 \mathrm{E}+01$ & $3.36 \mathrm{E}+01$ & $3.15 \mathrm{E}+01$ & $3.02 \mathrm{E}+01$ & $3.06 \mathrm{E}+01$ \\
\hline 90 & $6.57 \mathrm{E}+01$ & $6.72 \mathrm{E}+01$ & $6.62 \mathrm{E}+01$ & $6.57 \mathrm{E}+01$ & $5.29 \mathrm{E}+01$ & $5.44 \mathrm{E}+01$ & $5.13 \mathrm{E}+01$ & $5.08 \mathrm{E}+01$ \\
\hline 91 & $2.47 \mathrm{E}+01$ & $5.16 \mathrm{E}+01$ & $2.74 \mathrm{E}+01$ & $3.63 \mathrm{E}+01$ & $1.03 \mathrm{E}+01$ & $9.08 \mathrm{E}+00$ & $1.12 \mathrm{E}+01$ & $8.28 \mathrm{E}+00$ \\
\hline 92 & $<2.68 \mathrm{E}+01$ & $5.16 \mathrm{E}+01$ & $<3.13 \mathrm{E}+01$ & $4.78 \mathrm{E}+01$ & $<1.10 \mathrm{E}+01$ & $<1.11 \mathrm{E}+01$ & $1.15 \mathrm{E}+01$ & $<1.13 \mathrm{E}+01$ \\
\hline 93 & $<2.38 \mathrm{E}+01$ & $6.48 \mathrm{E}+01$ & $<3.35 \mathrm{E}+01$ & $4.97 \mathrm{E}+01$ & $1.03 \mathrm{E}+01$ & $1.12 \mathrm{E}+01$ & $1.18 \mathrm{E}+01$ & $1.44 \mathrm{E}+01$ \\
\hline 94 & $2.63 \mathrm{E}+01$ & $6.25 \mathrm{E}+01$ & $2.97 \mathrm{E}+01$ & $4.59 \mathrm{E}+01$ & $9.86 \mathrm{E}+00$ & $7.89 \mathrm{E}+00$ & $9.94 \mathrm{E}+00$ & $1.07 \mathrm{E}+01$ \\
\hline 96 & $2.45 \mathrm{E}+01$ & $5.69 \mathrm{E}+01$ & $3.70 \mathrm{E}+01$ & $4.66 \mathrm{E}+01$ & $1.20 \mathrm{E}+01$ & $1.24 \mathrm{E}+01$ & $1.21 \mathrm{E}+01$ & $<1.13 \mathrm{E}+01$ \\
\hline 101 & $7.19 \mathrm{E}+01$ & $7.15 \mathrm{E}+01$ & $6.94 \mathrm{E}+01$ & $7.28 \mathrm{E}+01$ & $3.26 \mathrm{E}+01$ & $2.55 \mathrm{E}+01$ & $2.80 \mathrm{E}+01$ & $3.00 \mathrm{E}+01$ \\
\hline 102 & $6.38 \mathrm{E}+01$ & $6.22 \mathrm{E}+01$ & $6.08 \mathrm{E}+01$ & $6.29 \mathrm{E}+01$ & $3.33 \mathrm{E}+01$ & $2.77 \mathrm{E}+01$ & $2.52 \mathrm{E}+01$ & $2.45 \mathrm{E}+01$ \\
\hline 103 & $3.13 \mathrm{E}+01$ & $3.03 \mathrm{E}+01$ & $3.17 \mathrm{E}+01$ & $3.42 \mathrm{E}+01$ & $1.30 \mathrm{E}+01$ & $9.64 \mathrm{E}+00$ & $1.28 \mathrm{E}+01$ & $1.04 \mathrm{E}+01$ \\
\hline 104 & $3.19 \mathrm{E}+01$ & $3.40 \mathrm{E}+01$ & $3.46 \mathrm{E}+01$ & $3.46 \mathrm{E}+01$ & $1.84 \mathrm{E}+01$ & $1.40 \mathrm{E}+01$ & $1.36 \mathrm{E}+01$ & $1.46 \mathrm{E}+01$ \\
\hline 110 & $7.90 \mathrm{E}+00$ & $7.93 \mathrm{E}+00$ & $7.10 \mathrm{E}+00$ & $8.81 \mathrm{E}+00$ & $7.17 \mathrm{E}+00$ & $4.44 \mathrm{E}+00$ & $<6.83 \mathrm{E}+00$ & $5.70 \mathrm{E}+00$ \\
\hline 111 & $1.17 \mathrm{E}+01$ & $<8.53 \mathrm{E}+00$ & $1.04 \mathrm{E}+01$ & $<7.71 \mathrm{E}+00$ & $<1.32 \mathrm{E}+01$ & $<1.33 \mathrm{E}+01$ & $<1.36 \mathrm{E}+01$ & $<1.35 \mathrm{E}+01$ \\
\hline 112 & $1.55 \mathrm{E}+01$ & $1.76 \mathrm{E}+01$ & $1.80 \mathrm{E}+01$ & $1.48 \mathrm{E}+01$ & $8.33 \mathrm{E}+00$ & $7.25 \mathrm{E}+00$ & $7.63 \mathrm{E}+00$ & $8.21 \mathrm{E}+00$ \\
\hline 114 & $2.26 \mathrm{E}+01$ & $2.17 \mathrm{E}+01$ & $2.38 \mathrm{E}+01$ & $2.48 \mathrm{E}+01$ & $1.20 \mathrm{E}+01$ & $1.52 \mathrm{E}+01$ & $1.28 \mathrm{E}+01$ & $1.47 \mathrm{E}+01$ \\
\hline 116 & $<7.76 \mathrm{E}+00$ & $<6.53 \mathrm{E}+00$ & $<7.88 \mathrm{E}+00$ & $<6.29 \mathrm{E}+00$ & $<6.61 \mathrm{E}+00$ & $<6.66 \mathrm{E}+00$ & $<6.80 \mathrm{E}+00$ & $<6.75 \mathrm{E}+00$ \\
\hline 119 & $8.80 \mathrm{E}+01$ & $9.06 \mathrm{E}+01$ & $8.26 \mathrm{E}+01$ & $8.63 \mathrm{E}+01$ & $1.05 \mathrm{E}+02$ & $8.07 \mathrm{E}+01$ & $8.75 \mathrm{E}+01$ & $8.53 \mathrm{E}+01$ \\
\hline 125 & $<2.19 \mathrm{E}+01$ & $<2.23 \mathrm{E}+01$ & $<2.21 \mathrm{E}+01$ & $<2.19 \mathrm{E}+01$ & $<1.32 \mathrm{E}+01$ & $<1.33 \mathrm{E}+01$ & $<1.36 \mathrm{E}+01$ & $<1.35 \mathrm{E}+01$ \\
\hline 133 & $<5.10 \mathrm{E}+00$ & $<5.07 \mathrm{E}+00$ & $<4.91 \mathrm{E}+00$ & $<4.86 \mathrm{E}+00$ & $8.02 \mathrm{E}+00$ & $6.76 \mathrm{E}+00$ & $6.85 \mathrm{E}+00$ & $6.75 \mathrm{E}+00$ \\
\hline 138 & $1.40 \mathrm{E}+02$ & $1.32 \mathrm{E}+02$ & $1.33 \mathrm{E}+02$ & $1.36 \mathrm{E}+02$ & $8.26 \mathrm{E}+00$ & $5.75 \mathrm{E}+00$ & $5.37 \mathrm{E}+00$ & $<4.50 \mathrm{E}+00$ \\
\hline 139 & $1.38 \mathrm{E}+02$ & $1.30 \mathrm{E}+02$ & $1.28 \mathrm{E}+02$ & $1.30 \mathrm{E}+02$ & $6.17 \mathrm{E}+01$ & $6.11 \mathrm{E}+01$ & $6.14 \mathrm{E}+01$ & $5.62 \mathrm{E}+01$ \\
\hline 140 & $1.35 \mathrm{E}+02$ & $1.31 \mathrm{E}+02$ & $1.28 \mathrm{E}+02$ & $1.33 \mathrm{E}+02$ & $8.85 \mathrm{E}+00$ & $9.46 \mathrm{E}+00$ & $7.93 \mathrm{E}+00$ & $7.09 \mathrm{E}+00$ \\
\hline 141 & $1.14 \mathrm{E}+02$ & $1.14 \mathrm{E}+02$ & $1.16 \mathrm{E}+02$ & $1.18 \mathrm{E}+02$ & $5.74 \mathrm{E}+01$ & $5.02 \mathrm{E}+01$ & $5.05 \mathrm{E}+01$ & $5.18 \mathrm{E}+01$ \\
\hline 142 & $<1.16 \mathrm{E}+02$ & $<1.17 \mathrm{E}+02$ & $<1.18 \mathrm{E}+02$ & $<1.24 \mathrm{E}+02$ & $8.82 \mathrm{E}+00$ & $8.88 \mathrm{E}+00$ & $9.07 \mathrm{E}+00$ & $9.01 \mathrm{E}+00$ \\
\hline 143 & $1.12 \mathrm{E}+02$ & $1.16 \mathrm{E}+02$ & $1.10 \mathrm{E}+02$ & $1.19 \mathrm{E}+02$ & $5.52 \mathrm{E}+01$ & $5.65 \mathrm{E}+01$ & $5.52 \mathrm{E}+01$ & $5.82 \mathrm{E}+01$ \\
\hline 144 & $1.26 \mathrm{E}+02$ & $1.24 \mathrm{E}+02$ & $1.23 \mathrm{E}+02$ & $1.26 \mathrm{E}+02$ & $5.61 \mathrm{E}+01$ & $5.03 \mathrm{E}+01$ & $5.06 \mathrm{E}+01$ & $4.72 \mathrm{E}+01$ \\
\hline 145 & $7.96 \mathrm{E}+01$ & $7.99 \mathrm{E}+01$ & $7.65 \mathrm{E}+01$ & $7.84 \mathrm{E}+01$ & $3.87 \mathrm{E}+01$ & $4.27 \mathrm{E}+01$ & $3.75 \mathrm{E}+01$ & $3.52 \mathrm{E}+01$ \\
\hline
\end{tabular}


SRNL-STI-2011-00622

Revision 0

\begin{tabular}{|c|c|c|c|c|c|c|c|c|}
\hline \multirow[b]{2}{*}{$\begin{array}{c}3002 \\
\mathrm{~m} / \mathrm{z}\end{array}$} & \multicolumn{4}{|c|}{ Aqua regia ICP-MS Slurry, mg/kg Slurry Basis } & \multicolumn{4}{|c|}{ Supernate Basis, mg/L } \\
\hline & $\begin{array}{c}1 \\
92359 \\
\mu \mathrm{g} / \mathrm{g}\end{array}$ & $\begin{array}{c}2 \\
92360 \\
\mu \mathrm{g} / \mathrm{g}\end{array}$ & $\begin{array}{c}3 \\
92361 \\
\mu \mathrm{g} / \mathrm{g}\end{array}$ & $\begin{array}{c}4 \\
92362 \\
\mu \mathrm{g} / \mathrm{g}\end{array}$ & $\begin{array}{c}1 \\
92352 \\
\mathrm{mg} / \mathrm{L}\end{array}$ & $\begin{array}{c}2 \\
92353 \\
\mathrm{mg} / \mathrm{L}\end{array}$ & $\begin{array}{c}3 \\
92354 \\
\mathrm{mg} / \mathrm{L}\end{array}$ & $\begin{array}{c}4 \\
92355 \\
\mathrm{mg} / \mathrm{L}\end{array}$ \\
\hline 146 & $5.86 \mathrm{E}+01$ & $6.95 \mathrm{E}+01$ & $6.68 \mathrm{E}+01$ & $6.10 \mathrm{E}+01$ & $3.68 \mathrm{E}+01$ & $3.09 \mathrm{E}+01$ & $3.09 \mathrm{E}+01$ & $3.20 \mathrm{E}+01$ \\
\hline 147 & $4.08 \mathrm{E}+01$ & $4.40 \mathrm{E}+01$ & $3.72 \mathrm{E}+01$ & $4.10 \mathrm{E}+01$ & $2.29 \mathrm{E}+01$ & $1.70 \mathrm{E}+01$ & $2.28 \mathrm{E}+01$ & $1.84 \mathrm{E}+01$ \\
\hline 148 & $4.63 \mathrm{E}+01$ & $4.39 \mathrm{E}+01$ & $3.84 \mathrm{E}+01$ & $4.14 \mathrm{E}+01$ & $2.27 \mathrm{E}+01$ & $2.16 \mathrm{E}+01$ & $1.89 \mathrm{E}+01$ & $1.91 \mathrm{E}+01$ \\
\hline 150 & $4.21 \mathrm{E}+01$ & $4.13 \mathrm{E}+01$ & $3.87 \mathrm{E}+01$ & $4.09 \mathrm{E}+01$ & $2.05 \mathrm{E}+01$ & $1.92 \mathrm{E}+01$ & $1.97 \mathrm{E}+01$ & $2.13 \mathrm{E}+01$ \\
\hline 152 & $1.28 \mathrm{E}+01$ & $1.34 \mathrm{E}+01$ & $1.08 \mathrm{E}+01$ & $1.30 \mathrm{E}+01$ & $7.37 \mathrm{E}+00$ & $5.79 \mathrm{E}+00$ & $6.82 \mathrm{E}+00$ & $8.31 \mathrm{E}+00$ \\
\hline 153 & $<5.30 \mathrm{E}+00$ & $<5.86 \mathrm{E}+00$ & $7.85 \mathrm{E}+00$ & $6.44 \mathrm{E}+00$ & $<4.41 \mathrm{E}+00$ & $<4.44 \mathrm{E}+00$ & $<5.98 \mathrm{E}+00$ & $<4.50 \mathrm{E}+00$ \\
\hline 154 & $<5.63 \mathrm{E}+00$ & $<6.64 \mathrm{E}+00$ & $8.25 \mathrm{E}+00$ & $9.06 \mathrm{E}+00$ & $5.06 \mathrm{E}+00$ & $5.77 \mathrm{E}+00$ & $5.76 \mathrm{E}+00$ & $6.20 \mathrm{E}+00$ \\
\hline 155 & $2.26 \mathrm{E}+01$ & $2.35 \mathrm{E}+01$ & $2.19 \mathrm{E}+01$ & $2.26 \mathrm{E}+01$ & $2.01 \mathrm{E}+01$ & $2.22 \mathrm{E}+01$ & $1.95 \mathrm{E}+01$ & $1.73 \mathrm{E}+01$ \\
\hline 156 & $3.54 \mathrm{E}+01$ & $3.49 \mathrm{E}+01$ & $3.17 \mathrm{E}+01$ & $2.92 \mathrm{E}+01$ & $2.90 \mathrm{E}+01$ & $2.58 \mathrm{E}+01$ & $2.63 \mathrm{E}+01$ & $2.54 \mathrm{E}+01$ \\
\hline 157 & $2.42 \mathrm{E}+01$ & $2.31 \mathrm{E}+01$ & $2.40 \mathrm{E}+01$ & $2.07 \mathrm{E}+01$ & $1.93 \mathrm{E}+01$ & $2.05 \mathrm{E}+01$ & $1.72 \mathrm{E}+01$ & $2.07 \mathrm{E}+01$ \\
\hline 158 & $3.39 \mathrm{E}+01$ & $3.74 \mathrm{E}+01$ & $3.49 \mathrm{E}+01$ & $3.52 \mathrm{E}+01$ & $3.24 \mathrm{E}+01$ & $2.96 \mathrm{E}+01$ & $2.69 \mathrm{E}+01$ & $2.76 \mathrm{E}+01$ \\
\hline 160 & $3.35 \mathrm{E}+01$ & $3.30 \mathrm{E}+01$ & $3.17 \mathrm{E}+01$ & $3.41 \mathrm{E}+01$ & $2.67 \mathrm{E}+01$ & $2.47 \mathrm{E}+01$ & $2.85 \mathrm{E}+01$ & $2.94 \mathrm{E}+01$ \\
\hline 235 & $6.43 \mathrm{E}+01$ & $6.81 \mathrm{E}+01$ & $6.35 \mathrm{E}+01$ & $5.88 \mathrm{E}+01$ & $5.25 \mathrm{E}+01$ & $5.87 \mathrm{E}+01$ & $5.71 \mathrm{E}+01$ & $5.77 \mathrm{E}+01$ \\
\hline 236 & $<9.74 \mathrm{E}+00$ & $<9.93 \mathrm{E}+00$ & $<9.81 \mathrm{E}+00$ & $<9.73 \mathrm{E}+00$ & $<1.54 \mathrm{E}+01$ & $<1.55 \mathrm{E}+01$ & $<1.59 \mathrm{E}+01$ & $<1.58 \mathrm{E}+01$ \\
\hline 237 & $1.27 \mathrm{E}+01$ & $1.44 \mathrm{E}+01$ & $1.99 \mathrm{E}+01$ & $1.58 \mathrm{E}+01$ & $1.03 \mathrm{E}+01$ & $1.09 \mathrm{E}+01$ & $1.47 \mathrm{E}+01$ & $1.43 \mathrm{E}+01$ \\
\hline 238 & $8.90 \mathrm{E}+03$ & $9.02 \mathrm{E}+03$ & $8.83 \mathrm{E}+03$ & $8.84 \mathrm{E}+03$ & $8.21 \mathrm{E}+03$ & $7.78 \mathrm{E}+03$ & $7.54 \mathrm{E}+03$ & $7.76 \mathrm{E}+03$ \\
\hline 239 & $6.57 \mathrm{E}+01$ & $7.49 \mathrm{E}+01$ & $7.18 \mathrm{E}+01$ & $5.84 \mathrm{E}+01$ & $2.78 \mathrm{E}+01$ & $2.66 \mathrm{E}+01$ & $2.11 \mathrm{E}+01$ & $2.12 \mathrm{E}+01$ \\
\hline
\end{tabular}


SRNL-STI-2011-00622

Revision 0

Table D - 13. SRAT Product pH 1 ICP-MS

\begin{tabular}{|c|c|c|c|c|c|c|c|c|}
\hline \multirow[b]{2}{*}{$\begin{array}{c}3002 \\
\mathrm{~m} / \mathrm{z}\end{array}$} & \multicolumn{4}{|c|}{ Aqua regia ICP-MS, mg/kg Slurry Basis } & \multicolumn{4}{|c|}{ Supernate Basis, mg/L } \\
\hline & $\begin{array}{c}1 \\
92329 \\
\mu \mathrm{g} / \mathrm{g}\end{array}$ & $\begin{array}{c}2 \\
92330 \\
\mu \mathrm{g} / \mathrm{g}\end{array}$ & $\begin{array}{c}3 \\
92331 \\
\mu \mathrm{g} / \mathrm{g}\end{array}$ & $\begin{array}{c}4 \\
92332 \\
\mu \mathrm{g} / \mathrm{g}\end{array}$ & $\begin{array}{c}1 \\
92563 \\
\mathrm{mg} / \mathrm{L}\end{array}$ & $\begin{array}{c}2 \\
92564 \\
\mathrm{mg} / \mathrm{L}\end{array}$ & $\begin{array}{c}3 \\
92565 \\
\mathrm{mg} / \mathrm{L}\end{array}$ & $\begin{array}{c}4 \\
92566 \\
\mathrm{mg} / \mathrm{L}\end{array}$ \\
\hline 59 & $2.09 \mathrm{E}+01$ & $1.72 \mathrm{E}+01$ & $1.88 \mathrm{E}+01$ & $1.80 \mathrm{E}+01$ & $5.60 \mathrm{E}+00$ & $8.48 \mathrm{E}+00$ & $6.48 \mathrm{E}+00$ & $1.02 \mathrm{E}+01$ \\
\hline 88 & $5.28 \mathrm{E}+01$ & $5.07 \mathrm{E}+01$ & $5.56 \mathrm{E}+01$ & $4.90 \mathrm{E}+01$ & $4.63 \mathrm{E}+01$ & $4.92 \mathrm{E}+01$ & $5.12 \mathrm{E}+01$ & $5.82 \mathrm{E}+01$ \\
\hline 89 & $5.70 \mathrm{E}+01$ & $5.50 \mathrm{E}+01$ & $5.39 \mathrm{E}+01$ & $5.12 \mathrm{E}+01$ & $3.60 \mathrm{E}+01$ & $3.52 \mathrm{E}+01$ & $3.55 \mathrm{E}+01$ & $4.03 \mathrm{E}+01$ \\
\hline 90 & $6.14 \mathrm{E}+01$ & $6.10 \mathrm{E}+01$ & $4.88 \mathrm{E}+01$ & $5.09 \mathrm{E}+01$ & $3.89 \mathrm{E}+01$ & $4.13 \mathrm{E}+01$ & $4.46 \mathrm{E}+01$ & $4.36 \mathrm{E}+01$ \\
\hline 91 & $5.03 \mathrm{E}+01$ & $5.40 \mathrm{E}+01$ & $3.42 \mathrm{E}+01$ & $3.94 \mathrm{E}+01$ & $6.12 \mathrm{E}+00$ & $5.98 \mathrm{E}+00$ & $6.58 \mathrm{E}+00$ & $5.49 \mathrm{E}+00$ \\
\hline 92 & $<5.06 \mathrm{E}+01$ & $<6.06 \mathrm{E}+01$ & $<4.90 \mathrm{E}+01$ & $<4.52 \mathrm{E}+01$ & $<1.14 \mathrm{E}+01$ & $<1.13 \mathrm{E}+01$ & $<1.13 \mathrm{E}+01$ & $<1.14 \mathrm{E}+01$ \\
\hline 93 & $<6.89 \mathrm{E}+01$ & $<6.29 \mathrm{E}+01$ & $<4.90 \mathrm{E}+01$ & $<5.33 \mathrm{E}+01$ & $<1.14 \mathrm{E}+01$ & $<1.13 \mathrm{E}+01$ & $<1.13 \mathrm{E}+01$ & $<1.14 \mathrm{E}+01$ \\
\hline 94 & $6.11 \mathrm{E}+01$ & $8.17 \mathrm{E}+01$ & $4.16 \mathrm{E}+01$ & $5.13 \mathrm{E}+01$ & $7.17 \mathrm{E}+00$ & $8.26 \mathrm{E}+00$ & $5.70 \mathrm{E}+00$ & $5.98 \mathrm{E}+00$ \\
\hline 96 & $6.54 \mathrm{E}+01$ & $6.17 \mathrm{E}+01$ & $4.61 \mathrm{E}+01$ & $5.35 \mathrm{E}+01$ & $6.64 \mathrm{E}+00$ & $7.98 \mathrm{E}+00$ & $9.92 \mathrm{E}+00$ & $7.59 \mathrm{E}+00$ \\
\hline 101 & $7.22 \mathrm{E}+01$ & $6.82 \mathrm{E}+01$ & $7.15 \mathrm{E}+01$ & $6.90 \mathrm{E}+01$ & $3.01 \mathrm{E}+01$ & $2.39 \mathrm{E}+01$ & $2.70 \mathrm{E}+01$ & $2.45 \mathrm{E}+01$ \\
\hline 102 & $6.28 \mathrm{E}+01$ & $6.50 \mathrm{E}+01$ & $5.98 \mathrm{E}+01$ & $6.47 \mathrm{E}+01$ & $2.57 \mathrm{E}+01$ & $2.24 \mathrm{E}+01$ & $2.29 \mathrm{E}+01$ & $2.67 \mathrm{E}+01$ \\
\hline 103 & $3.91 \mathrm{E}+01$ & $3.66 \mathrm{E}+01$ & $5.12 \mathrm{E}+01$ & $2.97 \mathrm{E}+01$ & $9.10 \mathrm{E}+00$ & $8.29 \mathrm{E}+00$ & $6.77 \mathrm{E}+00$ & $8.51 \mathrm{E}+00$ \\
\hline 104 & $3.72 \mathrm{E}+01$ & $3.58 \mathrm{E}+01$ & $3.50 \mathrm{E}+01$ & $3.42 \mathrm{E}+01$ & $1.38 \mathrm{E}+01$ & $1.54 \mathrm{E}+01$ & $1.48 \mathrm{E}+01$ & $1.33 \mathrm{E}+01$ \\
\hline 110 & $7.31 \mathrm{E}+00$ & $<7.42 \mathrm{E}+00$ & $<1.13 \mathrm{E}+01$ & $7.96 \mathrm{E}+00$ & $7.19 \mathrm{E}+00$ & $<4.53 \mathrm{E}+00$ & $<4.50 \mathrm{E}+00$ & $6.77 \mathrm{E}+00$ \\
\hline 111 & $<9.25 \mathrm{E}+00$ & $<8.79 \mathrm{E}+00$ & $9.63 \mathrm{E}+00$ & $8.37 \mathrm{E}+00$ & $<6.83 \mathrm{E}+00$ & $<6.80 \mathrm{E}+00$ & $1.10 \mathrm{E}+01$ & $7.16 \mathrm{E}+00$ \\
\hline 112 & $1.81 \mathrm{E}+01$ & $2.12 \mathrm{E}+01$ & $1.76 \mathrm{E}+01$ & $1.80 \mathrm{E}+01$ & $1.55 \mathrm{E}+01$ & $9.18 \mathrm{E}+00$ & $1.04 \mathrm{E}+01$ & $9.12 \mathrm{E}+00$ \\
\hline 114 & $2.12 \mathrm{E}+01$ & $2.27 \mathrm{E}+01$ & $2.12 \mathrm{E}+01$ & $1.88 \mathrm{E}+01$ & $1.31 \mathrm{E}+01$ & $1.27 \mathrm{E}+01$ & $1.57 \mathrm{E}+01$ & $1.38 \mathrm{E}+01$ \\
\hline 116 & $<7.05 \mathrm{E}+00$ & $<7.02 \mathrm{E}+00$ & $<6.26 \mathrm{E}+00$ & $<8.55 \mathrm{E}+00$ & $<4.55 \mathrm{E}+00$ & $<4.53 \mathrm{E}+00$ & $<4.50 \mathrm{E}+00$ & $<4.54 \mathrm{E}+00$ \\
\hline 119 & $7.95 \mathrm{E}+01$ & $8.37 \mathrm{E}+01$ & $8.10 \mathrm{E}+01$ & $8.12 \mathrm{E}+01$ & $8.59 \mathrm{E}+01$ & $8.51 \mathrm{E}+01$ & $7.84 \mathrm{E}+01$ & $8.43 \mathrm{E}+01$ \\
\hline 125 & $<9.96 \mathrm{E}+00$ & $<9.83 \mathrm{E}+00$ & $9.89 \mathrm{E}+00$ & $<9.46 \mathrm{E}+00$ & $<4.55 \mathrm{E}+00$ & $4.53 \mathrm{E}+00$ & $<5.64 \mathrm{E}+00$ & $<4.54 \mathrm{E}+00$ \\
\hline 133 & $<4.76 \mathrm{E}+00$ & $<4.75 \mathrm{E}+00$ & $<4.30 \mathrm{E}+01$ & $<3.55 \mathrm{E}+00$ & $<4.55 \mathrm{E}+00$ & $<4.53 \mathrm{E}+00$ & $<4.50 \mathrm{E}+00$ & $<4.54 \mathrm{E}+00$ \\
\hline 138 & $1.38 \mathrm{E}+02$ & $1.35 \mathrm{E}+02$ & $1.33 \mathrm{E}+02$ & $1.28 \mathrm{E}+02$ & $1.27 \mathrm{E}+01$ & $1.01 \mathrm{E}+01$ & $9.18 \mathrm{E}+00$ & $4.03 \mathrm{E}+01$ \\
\hline 139 & $1.36 \mathrm{E}+02$ & $1.36 \mathrm{E}+02$ & $1.31 \mathrm{E}+02$ & $1.30 \mathrm{E}+02$ & $6.46 \mathrm{E}+01$ & $6.59 \mathrm{E}+01$ & $6.09 \mathrm{E}+01$ & $6.96 \mathrm{E}+01$ \\
\hline 140 & $1.34 \mathrm{E}+02$ & $1.32 \mathrm{E}+02$ & $1.26 \mathrm{E}+02$ & $1.27 \mathrm{E}+02$ & $8.17 \mathrm{E}+00$ & $9.73 \mathrm{E}+00$ & $8.52 \mathrm{E}+00$ & $1.62 \mathrm{E}+01$ \\
\hline 141 & $1.15 \mathrm{E}+02$ & $1.16 \mathrm{E}+02$ & $1.12 \mathrm{E}+02$ & $1.13 \mathrm{E}+02$ & $6.27 \mathrm{E}+01$ & $5.76 \mathrm{E}+01$ & $5.88 \mathrm{E}+01$ & $5.74 \mathrm{E}+01$ \\
\hline 142 & $<1.21 \mathrm{E}+02$ & $<1.22 \mathrm{E}+02$ & $<1.20 \mathrm{E}+02$ & $<1.20 \mathrm{E}+02$ & $<9.11 \mathrm{E}+00$ & $<9.07 \mathrm{E}+00$ & $<9.00 \mathrm{E}+00$ & $1.02 \mathrm{E}+01$ \\
\hline 143 & $1.15 \mathrm{E}+02$ & $1.15 \mathrm{E}+02$ & $1.17 \mathrm{E}+02$ & $1.17 \mathrm{E}+02$ & $5.96 \mathrm{E}+01$ & $6.09 \mathrm{E}+01$ & $6.20 \mathrm{E}+01$ & $6.00 \mathrm{E}+01$ \\
\hline 144 & $1.23 \mathrm{E}+02$ & $1.21 \mathrm{E}+02$ & $1.18 \mathrm{E}+02$ & $1.19 \mathrm{E}+02$ & $5.79 \mathrm{E}+01$ & $5.54 \mathrm{E}+01$ & $5.20 \mathrm{E}+01$ & $5.69 \mathrm{E}+01$ \\
\hline 145 & $8.04 \mathrm{E}+01$ & $8.20 \mathrm{E}+01$ & $8.06 \mathrm{E}+01$ & $8.09 \mathrm{E}+01$ & $4.51 \mathrm{E}+01$ & $4.27 \mathrm{E}+01$ & $4.58 \mathrm{E}+01$ & $4.40 \mathrm{E}+01$ \\
\hline
\end{tabular}


SRNL-STI-2011-00622

Revision 0

\begin{tabular}{|c|c|c|c|c|c|c|c|c|}
\hline \multirow[b]{2}{*}{$\begin{array}{c}3002 \\
\mathrm{~m} / \mathrm{z}\end{array}$} & \multicolumn{4}{|c|}{ Aqua regia ICP-MS, mg/kg Slurry Basis } & \multicolumn{4}{|c|}{ Supernate Basis, mg/L } \\
\hline & $\begin{array}{c}1 \\
92329 \\
\mu \mathrm{g} / \mathrm{g}\end{array}$ & $\begin{array}{c}2 \\
92330 \\
\mu \mathrm{g} / \mathrm{g}\end{array}$ & $\begin{array}{c}3 \\
92331 \\
\mu \mathrm{g} / \mathrm{g}\end{array}$ & $\begin{array}{c}4 \\
92332 \\
\mu \mathrm{g} / \mathrm{g}\end{array}$ & $\begin{array}{c}1 \\
92563 \\
\mathrm{mg} / \mathrm{L}\end{array}$ & $\begin{array}{c}2 \\
92564 \\
\mathrm{mg} / \mathrm{L}\end{array}$ & $\begin{array}{c}3 \\
92565 \\
\mathrm{mg} / \mathrm{L}\end{array}$ & $\begin{array}{c}4 \\
92566 \\
\mathrm{mg} / \mathrm{L}\end{array}$ \\
\hline 146 & $6.52 \mathrm{E}+01$ & $6.33 \mathrm{E}+01$ & $6.39 \mathrm{E}+01$ & $6.53 \mathrm{E}+01$ & $3.48 \mathrm{E}+01$ & $3.89 \mathrm{E}+01$ & $3.55 \mathrm{E}+01$ & $3.63 \mathrm{E}+01$ \\
\hline 147 & $4.06 \mathrm{E}+01$ & $4.32 \mathrm{E}+01$ & $4.27 \mathrm{E}+01$ & $4.45 \mathrm{E}+01$ & $2.74 \mathrm{E}+01$ & $2.68 \mathrm{E}+01$ & $2.40 \mathrm{E}+01$ & $2.17 \mathrm{E}+01$ \\
\hline 148 & $4.17 \mathrm{E}+01$ & $4.26 \mathrm{E}+01$ & $3.82 \mathrm{E}+01$ & $3.83 \mathrm{E}+01$ & $2.46 \mathrm{E}+01$ & $2.28 \mathrm{E}+01$ & $2.28 \mathrm{E}+01$ & $2.41 \mathrm{E}+01$ \\
\hline 150 & $3.67 \mathrm{E}+01$ & $3.62 \mathrm{E}+01$ & $3.77 \mathrm{E}+01$ & $3.66 \mathrm{E}+01$ & $2.22 \mathrm{E}+01$ & $2.26 \mathrm{E}+01$ & $2.12 \mathrm{E}+01$ & $2.04 \mathrm{E}+01$ \\
\hline 152 & $1.20 \mathrm{E}+01$ & $1.28 \mathrm{E}+01$ & $1.21 \mathrm{E}+01$ & $1.26 \mathrm{E}+01$ & $7.14 \mathrm{E}+00$ & $6.94 \mathrm{E}+00$ & $7.72 \mathrm{E}+00$ & $8.08 \mathrm{E}+00$ \\
\hline 153 & $6.60 \mathrm{E}+00$ & $<5.02 \mathrm{E}+00$ & $<5.03 \mathrm{E}+00$ & $6.93 \mathrm{E}+00$ & $4.67 \mathrm{E}+00$ & $<4.53 \mathrm{E}+00$ & $<4.50 \mathrm{E}+00$ & $5.67 \mathrm{E}+00$ \\
\hline 154 & $5.92 \mathrm{E}+00$ & $4.79 E+00$ & $<5.66 \mathrm{E}+00$ & $<5.66 \mathrm{E}+00$ & $5.64 \mathrm{E}+00$ & $5.70 \mathrm{E}+00$ & $<4.50 \mathrm{E}+00$ & $<4.54 \mathrm{E}+00$ \\
\hline 155 & $2.34 \mathrm{E}+01$ & $1.93 \mathrm{E}+01$ & $2.05 \mathrm{E}+01$ & $2.10 \mathrm{E}+01$ & $1.78 \mathrm{E}+01$ & $2.15 \mathrm{E}+01$ & $1.80 \mathrm{E}+01$ & $1.80 \mathrm{E}+01$ \\
\hline 156 & $3.54 \mathrm{E}+01$ & $3.36 \mathrm{E}+01$ & $3.16 \mathrm{E}+01$ & $3.34 \mathrm{E}+01$ & $2.50 \mathrm{E}+01$ & $2.65 \mathrm{E}+01$ & $2.65 \mathrm{E}+01$ & $2.36 \mathrm{E}+01$ \\
\hline 157 & $2.36 \mathrm{E}+01$ & $2.21 \mathrm{E}+01$ & $2.05 \mathrm{E}+01$ & $2.12 \mathrm{E}+01$ & $1.68 \mathrm{E}+01$ & $2.09 \mathrm{E}+01$ & $1.98 \mathrm{E}+01$ & $1.82 \mathrm{E}+01$ \\
\hline 158 & $3.66 \mathrm{E}+01$ & $3.59 \mathrm{E}+01$ & $3.63 \mathrm{E}+01$ & $3.56 \mathrm{E}+01$ & $2.96 \mathrm{E}+01$ & $3.34 \mathrm{E}+01$ & $3.04 \mathrm{E}+01$ & $2.67 \mathrm{E}+01$ \\
\hline 160 & $3.30 \mathrm{E}+01$ & $3.17 \mathrm{E}+01$ & $3.31 \mathrm{E}+01$ & $3.14 \mathrm{E}+01$ & $2.23 \mathrm{E}+01$ & $2.56 \mathrm{E}+01$ & $2.86 \mathrm{E}+01$ & $2.33 \mathrm{E}+01$ \\
\hline 235 & $6.27 \mathrm{E}+01$ & $6.49 \mathrm{E}+01$ & $6.33 \mathrm{E}+01$ & $6.15 \mathrm{E}+01$ & $6.17 \mathrm{E}+01$ & $6.06 \mathrm{E}+01$ & $5.26 \mathrm{E}+01$ & $5.84 \mathrm{E}+01$ \\
\hline 236 & $<4.40 \mathrm{E}+00$ & $<5.29 \mathrm{E}+00$ & $<5.17 \mathrm{E}+00$ & $<5.64 \mathrm{E}+00$ & $<9.11 \mathrm{E}+00$ & $<9.07 \mathrm{E}+00$ & $<9.00 \mathrm{E}+00$ & $<9.09 \mathrm{E}+00$ \\
\hline 237 & $1.16 \mathrm{E}+01$ & $1.37 \mathrm{E}+01$ & $1.55 \mathrm{E}+01$ & $1.44 \mathrm{E}+01$ & $1.32 \mathrm{E}+01$ & $1.60 \mathrm{E}+01$ & $1.31 \mathrm{E}+01$ & $1.38 \mathrm{E}+01$ \\
\hline 238 & $9.42 \mathrm{E}+03$ & $9.17 \mathrm{E}+03$ & $9.48 \mathrm{E}+03$ & $9.32 \mathrm{E}+03$ & $8.41 \mathrm{E}+03$ & $8.47 \mathrm{E}+03$ & $8.40 \mathrm{E}+03$ & $8.16 \mathrm{E}+03$ \\
\hline 239 & $6.57 \mathrm{E}+01$ & $6.14 \mathrm{E}+01$ & $6.78 \mathrm{E}+01$ & $6.62 \mathrm{E}+01$ & $1.94 \mathrm{E}+01$ & $1.98 \mathrm{E}+01$ & $<1.58 \mathrm{E}+01$ & $<1.59 \mathrm{E}+01$ \\
\hline
\end{tabular}




\section{Distribution:}
A. B. Barnes, 999-W
S. D. Fink, 773-A
B. J. Giddings, 786-5A
C. C. Herman, 999-W
S. L. Marra, 773-A
F. M. Pennebaker, 773-42A
W. R. Wilmarth, 773-A
J. M. Gillam, 766-H
J. F. Iaukea, 704-30S
J. E. Occhipinti, 704-S
W. O Pepper, 704-S
D. K. Peeler, 999-W
J. W. Ray, 704-S
H. B. Shah, 766-H
D. C. Sherburne, 704-S
M. E. Stone, 999-W
B. R. Pickenheim, 704-28S
J. R. Zamecnik, 999-W
M. A. Broome, 704-29S
R. N. Hinds, 704-S
J. P. Vaughan, 773-41A
J. M. Bricker, 704-27S
T. L. Fellinger, 704-26S
E. W. Holtzscheiter, 704-15S
A. V. Staub, 704-27S
K. R. Shah, 704-S
M. E. Smith, 704-30S
M. T. Keefer, 766-H
D. P. Lambert, 999-W
D. C. Koopman, 999-W
J. D. Newell, 999-W
D. R. Best, 999-W
R. E. Eibling, 999-W
W. T. Riley, 999-W
P. R. Jackson, 703-46A 